\title{
Impact of Melter Internal Design on Off-Gas Flammability
}

\author{
A. S. Choi \\ S. Y. Lee
}

May 2012

Savannah River National Laboratory Savannah River Nuclear Solutions, LLC Aiken, SC 29808

Prepared for the U.S. Department of Energy under contract number DE-AC09-08SR22470. 
SRNL-STI-2012-00121

Revision 0

\section{DISCLAIMER}

This work was prepared under an agreement with and funded by the U.S. Government. Neither the U.S. Government or its employees, nor any of its contractors, subcontractors or their employees, makes any express or implied:

1. warranty or assumes any legal liability for the accuracy, completeness, or for the use or results of such use of any information, product, or process disclosed; or

2. representation that such use or results of such use would not infringe privately owned rights; or

3. endorsement or recommendation of any specifically identified commercial product, process, or service.

Any views and opinions of authors expressed in this work do not necessarily state or reflect those of the United States Government, or its contractors, or subcontractors.

\section{Printed in the United States of America \\ Prepared for \\ U.S. Department of Energy}


Keywords: $D W P F$, Melter OffGas Flammability Model, Melter Design

Retention: Permanent

\title{
Impact of Melter Internal Design on Off-Gas Flammability
}

\author{
A. S. Choi \\ S. Y. Lee
}

May 2012

Savannah River National Laboratory Savannah River Nuclear Solutions, LLC Aiken, SC 29808

Prepared for the U.S. Department of Energy under contract number DE-AC09-08SR22470. 


\section{REVIEWS AND APPROVALS}

\section{AUTHORS:}

\begin{tabular}{ll}
\hline A. S. Choi, Engineering Process Development Date &
\end{tabular}

S. Y. Lee, Applied Computational Engineering \& Statistics

Date

TECHNICAL REVIEW:

F. G. Smith, III, Process Modeling \& Computational Chemistry

Date

J. R. Zamecnik, Process Technology Programs

Date

APPROVAL:

C. C. Herman, Manager

Date

Process Technology Programs

S.L. Marra, Manager

Date

Environmental \& Chemical Process Technology Research Programs

J. E. Occhipinti, Manager

Date

DWPF Engineering/Savannah River Remediation 


\section{EXECUTIVE SUMMARY}

The Defense Waste Processing Facility (DWPF) is planning to make a major flowsheet change by replacing formic acid with glycolic acid as the baseline reductant for adjusting the high-level waste (HLW) feed for the melter. One of the flowsheet demonstration tests to be performed prior to implementation involves feeding the glycolic acid process feed to a pilot-scale melter and characterizing its off-gas to establish the technical bases for the melter off-gas flammability safety analysis. In addition, the surging potential of the new feed in terms of both condensable and non-condensable off-gas flows also has to be quantified during the test in order to define the baseline melter transient for the safety analysis of the glycolic-acid flowsheet feed. It is also of vital importance to analyze the off-gas condensate produced during the pilot-melter test for the presence of glycolate or any other organic species that may pose operational difficulties on the downstream processes.

The data to be generated during the pilot-melter testing should be readily scalable to the DWPF melter so that they can be used not only as part of the safety basis but as the baseline data from which to extract the global kinetic parameters for the DWPF melter combustion model as well as to develop the new cold cap reactions for the staged thermodynamic equilibrium model. Since the combustion efficiency is dependent upon not only the gas temperature profile but the mode of mixing between the fuel and air in the vapor space, the global kinetic parameters thus extracted should reflect not only the intrinsic kinetics of combustion reactions but the transport effects such as fluid mixing and heat transfer in the DWPF melter vapor space. Therefore, the melter selected as the platform for the pilot testing should be as large and as prototypic of the DWPF melter as practically possible so that the flow and temperature fields as well as the cold cap behavior of the pilot melter closely resemble those of the DWPF melter.

The purpose of this study was then to: (1) identify the more dominant design parameters that can serve as the quantitative measure of how prototypic a given melter is, (2) run the existing DWPF models to simulate the data collected using both DWPF and non-DWPF melter configurations, (3) confirm the validity of the selected design parameters by determining if the agreement between the model predictions and data is reasonably good in light of the design and operating conditions employed in each data set, and (4) run Computational Fluid Dynamics (CFD) simulations to gain new insights into how fluid mixing is affected by the configuration of melter internals and to further apply the new insights to explaining, for example, why the agreement is not good.

Fluid mixing and heat transfer in the vapor space are impacted primarily by the internal design of a melter such as the geometry of melter cavity, configuration of the vapor space heaters, mode of air injection, and relative locations of air inlet and melter exhaust ports. In an effort to reduce the number of variables to be investigated to a more manageable level, the major focus of this study was put on the impact of melter cavity design on off-gas flammability, while the effects of other design variables were discussed in conjunction with the main variables, as necessary. The first design parameter selected for the melter cavity is the vapor space-to-melt pool cross-sectional area ratio, which is a measure of how much the cold cap off-gas needs to expand or even contract upon entering the vapor space as well as how much radiant heat the cold cap receives. Obviously, the higher the vapor space-to-melt pool cross-sectional area ratio, the more refractory surfaces the cold cap will see and therefore receives more radiant heat. The second design parameter selected is called the melt pool aspect ratio defined as the ratio of melt surface diameter to melt pool depth. Thus, the smaller the melt pool aspect ratio, the deeper the melt pool relative to its diameter. The melt pool aspect ratio appears to impact cold cap behavior particularly in bubbled melters. 
A total of six non-DWPF melter data sets were analyzed in this study. The design and operating conditions under which these melters were run varied greatly in their feed chemistry, reductants used, mode of air purge, and bubbled vs. non-bubbled. The first data set was collected during the Pilot Scale Ceramic Melter Run 23 (PSCM-23) at the Pacific Northwest National Laboratory (PNNL) without the use of bubblers. Except for having a rectangular cross-section, the internal design of the PSCM was prototypic of the DWPF melter since its vapor space-to-melt pool crosssectional area ratio and melt pool aspect ratio were 1.0 and 2.6, respectively, compared to the corresponding DWPF values of 1.1 and 2.1. In addition, the calculated gas residence time of 6.7 seconds in the PSCM vapor space was right in line with the nominal DWPF value of 7 seconds. The feed used was Hanford HLW simulant neutralized with formic acid and further augmented with sugar for the target glass redox of $<0.3$. The concentrations of $\mathrm{H}_{2}$ and $\mathrm{CO}$ in the quenched off-gas predicted by the DWPF models were found to be in excellent agreement with the data.

The second and third data sets came from a series of Research Scale Melter (RSM) runs at the PNNL in 2003 using glass bubblers. Despite its small size, $\sim 1 / 140^{\text {th }}$ scale based on melt surface area, the internal design of the RSM was more prototypic of the DWPF melter than the PSCM23; it had a cylindrical cavity and its vapor space-to-melt pool cross-sectional area ratio and melt pool aspect ratio were 1.0 and 2.0, respectively. The baseline feed for the RSM runs was Hanford Tank C-104/AY-101 simulant. The second data set was produced from the baseline feed spiked with low $\mathrm{Hg}$ but high $\mathrm{NaCl}$ and sugar, termed RSM-LHH, while the third data set was produced from the baseline feed spiked with the maximum level of $\mathrm{Hg}$ and high $\mathrm{NaCl}$ and sugar, termed RSM-MHH. It was found that the DWPF models over predicted the measured concentrations of $\mathrm{H}_{2}$ and $\mathrm{CO}$ produced from the RSM-LHH feed. The calculated gas residence time in the RSM vapor space was short at 1.1 second, since it was run at relatively high feed rates compared to its size. When the models were re-run by arbitrarily increasing the gas residence time to 3 seconds, the calculated concentrations decreased to be more in line with the data, which suggested that the gas residence time of $\sim 1$ second may be outside the range of the DWPF global combustion model. For the RSM-MHH feed, the agreement between the calculated and measured concentrations of $\mathrm{H}_{2}$ and $\mathrm{CO}$ was already good without any adjustments, although the calculated gas residence time was only a fraction of a second longer than that of the RSM-LHH run. More importantly, however, since the measured $\mathrm{H}_{2}$ and $\mathrm{CO}$ data were near detection limits during both RSM runs, the most that can be concluded is that the model predictions were consistent with the data.

The fourth and fifth data set came from the DM10 runs at the Vitreous State Laboratory (VSL) using Hanford's LAW sub-Envelope A2 simulant with sugar as the reductant, called DM10-A2 and the DWPF SB6 simulant with formic acid as the reductant, called DM10-SB6, respectively. Like the RSM, the DM10 is a $1 / 140^{\text {th }}$ scale melter based on melt surface area. Unlike the PSCM or RSM, however, its vapor space-to-melt pool cross-sectional area ratio of 5.8 and melt pool aspect ratio of 0.8 are both quite different from the corresponding DWPF values of 1.1 and 2.1. Since the estimated gas temperature in the vapor space during both DM10 runs was below $200^{\circ} \mathrm{C}$, which is low enough to assume no vapor space combustion, only the DWPF cold cap model was run and found to under predict the measured concentrations of $\mathrm{H}_{2}$ and $\mathrm{CO}$ produced from either feed. The test conditions employed in each DM10 run were quite different: formic acid reductant, non-bubbled melt pool, and active air purging for the DM10-SB6 run vs. sugar reductant, bubbled melt pool, and passive air purging (i.e., air inleakage only) for the DM10-A2 run.

The sixth and final data set analyzed in this study came from the DM100 test in 2002 also at the VSL using glass bubblers. The DM100 is a $1 / 24^{\text {th }}$ scale melter based on melt surface area and its vapor space-to-melt pool cross-sectional area ratio of 3.3 and melt pool aspect ratio of 0.8 are also quite different from those of the DWPF melter, although the former is not as different as that of the DM10. The feed was the same sub-Envelope A2 simulant used in the DM10-A2 test but sugar 
was replaced with formic acid at the target nitrate/TOC molar ratio of 1/1.5. The DWPF models were again shown to under predict the measured $\mathrm{H}_{2}$ and $\mathrm{CO}$ data, as they did for both DM10 data. The fact that the DWPF models consistently under predicted both DM10 and DM100 data under diverse operating conditions seems to suggest that the degree of cold cap off-gas bypassing was greater in these melters than in either the PSCM or RSM, thus resulting in higher flammable gas concentrations than predicted by the DWPF cold cap model. Since gas bypassing in the cold cap is an integral part of slurry-fed melters, increased gas bypassing here simply means that the cold cap behaviors of the DM10 and DM100 deviated more from the ideally-staged thermodynamic equilibrium modeling construct used in the DWPF cold cap model. Further analysis of data also showed that the degree of deviation may be more design related rather than operational.

The vapor space-to-melt pool cross-sectional area ratios and melt pool aspect ratios of the SCM-2 and 774-A melter lie somewhere between those of the DWPF melter and those of the DM10 and DM100. So, the applicability of the DWPF models to the SCM-2 and 774-A runs was expected to be less robust than it was for either the PSCM-23 or RSM runs. Although the DWPF models were developed from the prototypic Scale Glass Melter (SGM) data, it was the data from the SCM-2 and 774-A melter runs against which they were validated. One common feature of the SCM-2 and 774-A melter runs is that both melters were run in the presence of active air purge into the vapor space. Active air purge is defined here as any air flow added intentionally in a controlled manner. In order to gain further insights into the impacts of active air purge as well as melter cavity design on the vapor space combustion efficiency, a CFD simulation study was performed using a threedimensional CFD code called FLUENT ${ }^{\circledR} 6.3$ to compute the gas flow fields and mixing profiles in the melter vapor space under various design and operating conditions.

One of the key findings of the CFD modeling was that the air purge discharging from the backup film cooler forms a jet impinging on the cold cap, thus enhancing turbulence and gas mixing over an expanded region of the vapor space even in a non-prototypic melter with the vapor space-tomelt pool cross-sectional area ratio much greater than 1 . It means that active air purging may be used in non-prototypic melters to induce enough turbulence and thus enough mixing of gases to compensate for their non-prototypic designs. However, one major drawback of active air purging is that it cools the vapor space, thus adversely affecting both combustion and glass production rates. In the absence of active air purging, both turbulence and gas mixing are strongly affected by the melter internal design particularly in terms of the vapor space-to-melt pool cross-sectional area ratio and, to a lesser extent, the vapor space aspect ratio.

In summary, the impact of melter internal design on the overall combustion efficiency was investigated in this study by means of a comprehensive review of relevant data in the literature, thermodynamic and kinetic modeling of melter reactions and, finally, CFD modeling of fluid mixing under various design and operating conditions. Based on the results of the data review and modeling, the following conclusions are drawn:

1. Since the DWPF global combustion model implicitly includes in its parameters such transport effects as fluid mixing and heat transfer as well as intrinsic kinetics, it should in principle be only applicable to the prototypic melters that exhibit similar transport effects.

2. When melter configurations were prototypic of the DWPF melter based on similar vapor space-to-melt pool cross-sectional area ratios and, to a lesser extent, similar melt pool aspect ratios, the existing DWPF cold cap and global combustion models successfully predicted measured $\mathrm{H}_{2}$ and $\mathrm{CO}$ data from the prototypic PSCM-23 run. Although the applicability of the DWPF models to the prototypic RSM run data could not be proved as 
firmly due to the fact that measured $\mathrm{H}_{2}$ and $\mathrm{CO}$ data were near detection limits, the model predictions were still found to be consistent with the data.

3. When melter configurations were non-prototypic of the DWPF melter based on dissimilar vapor space-to-melt pool cross-sectional area ratios and dissimilar melt pool aspect ratios, the existing DWPF cold cap model under predicted measured $\mathrm{H}_{2}$ and $\mathrm{CO}$ data from the non-prototypic DM10-A2 and DM10-SB6 runs.

4. The existing DWPF cold cap and global combustion models under predicted measured $\mathrm{H}_{2}$ and $\mathrm{CO}$ data from the non-prototypic DM100-A2 run. It is not known which of the two DWPF models is more responsible for the under prediction. If it were the cold cap model, gas bypassing would be the likely cause. If it were the global combustion model, nonrepresentative fluid mixing and heat transfer in the DM100 vapor space would be the likely cause.

5. The results of CFD modeling showed that active air purging greatly improves gas mixing in the melter vapor space, which appears to be the main reason for the successful validation of the DWPF models against the SCM-2 and 774-A melter run data despite their non-prototypic vapor space-to-melt pool cross-sectional area ratios.

6. However, one major drawback of active air purging is that it cools the vapor space and thus adversely affects both combustion and glass production rates. The rate of active air purge (per unit melt surface area) necessary to maintain comparable mixing efficiency increases with increasing vapor space-to-melt pool cross-sectional area ratio, since higher air purge would be required to maintain similar mixing profiles in a larger vapor space. This additional air purge necessary to overcome non-prototypic design and subsequent cooling of the vapor space would be difficult to scale up.

7. The results of CFD modeling also showed that in the absence of active air purge, the flow fields and mixing profiles in a prototypic melter vapor space are markedly different from those in a non-prototypic melter. Particularly, the passive cooling of the vapor space is much more pronounced in a non-prototypic melter than in a prototypic melter.

8. Since process chemistry, mixing, and heat transfer in the DWPF melter are represented by a simplified set of models, including the global kinetic model for the vapor space combustion, the further the test configurations deviate from the key design parameters described in this document, the greater the risk that the test results and conclusions will not represent the DWPF. As a result, scale-up of the data taken from a non-prototypic melter will be more challenging and, therefore, more risky than scale-up of the data taken from a prototypic melter. 


\section{TABLE OF CONTENTS}

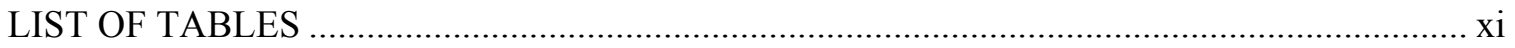

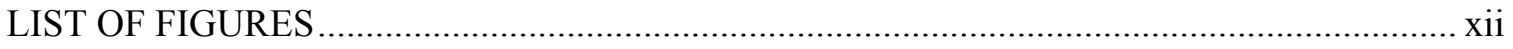

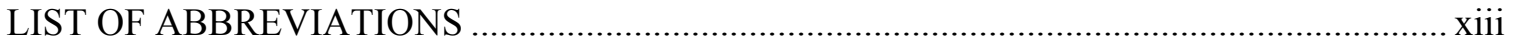

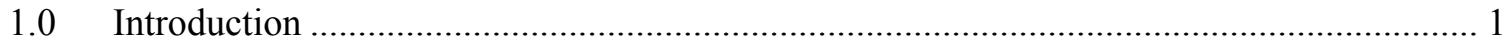

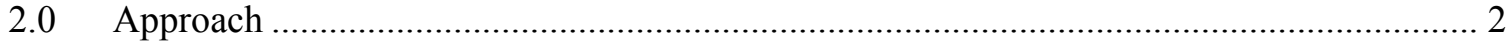

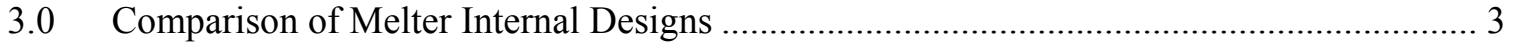

3.1 Impact of Melter Internal Design on Fluid Mixing ...................................................... 3

3.2 Impact of Melter Internal Design on Heat Transfer...................................................... 7

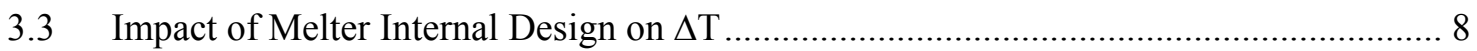

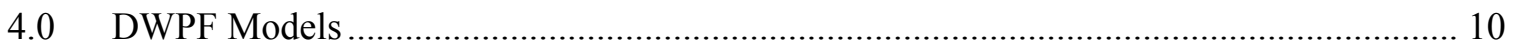

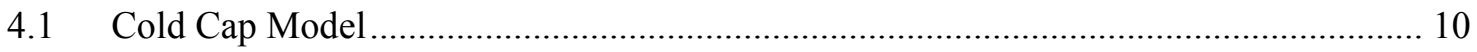

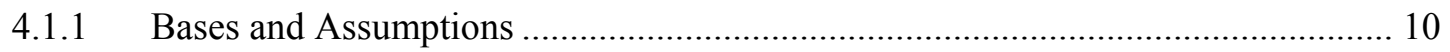

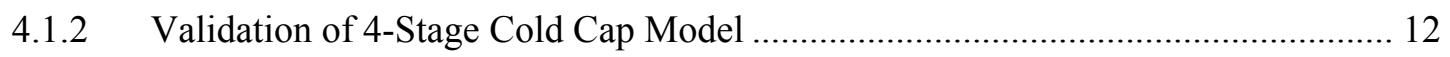

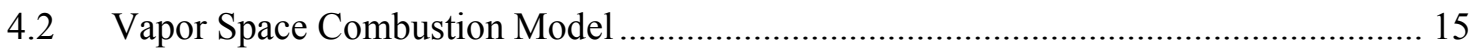

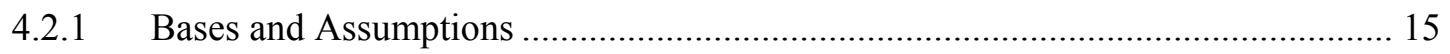

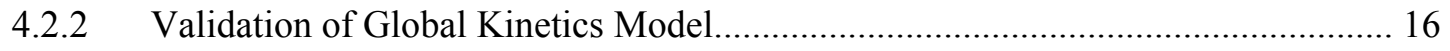

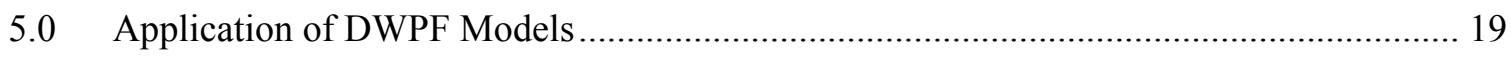

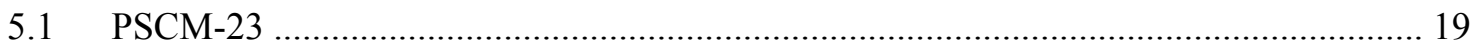

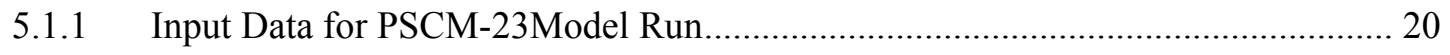

5.1.2 Results of DWPF Model Runs for PSCM-23 ...................................................... 20

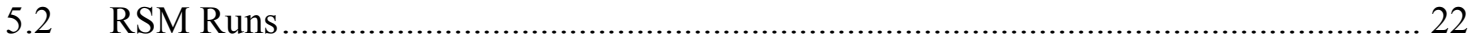

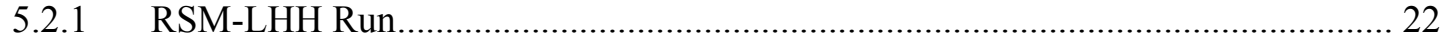

5.2.1.1 Input Data for RSM-LHH Model Run .......................................................... 22

5.2.1.2 Results of DWPF Model Runs for RSM-LHH............................................. 23

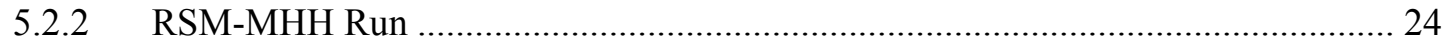

5.2.2.1 Input Data for RSM-MHH Model Run ...................................................... 25

5.2.2.2 Results of DWPF Model Runs for RSM-MHH............................................. 26

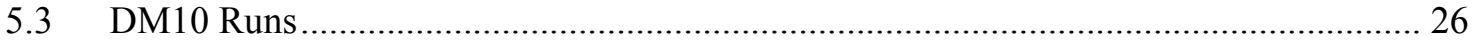

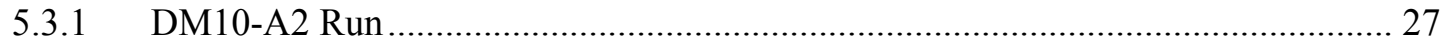

5.3.1.1 Input Data for DM10-A2 Model Run......................................................... 27

5.3.1.2 Results of DWPF Model Runs for DM10-A2 ............................................ 28 


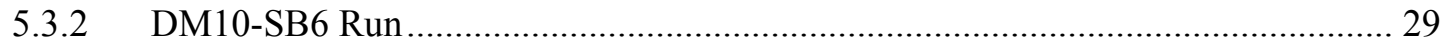

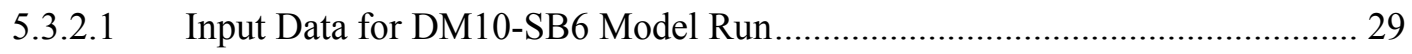

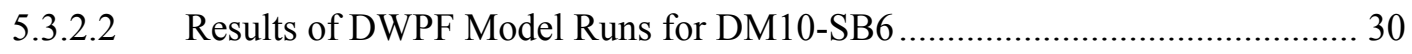

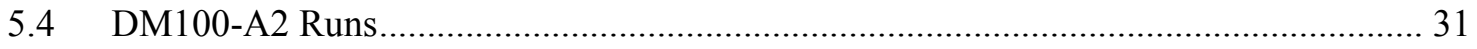

5.4.1 Input Data for DM100-A2 Model Run ................................................................. 31

5.4.2 Results of DWPF Model Run for DM100-A2 …................................................. 32

5.5 Summary of DWPF Model Simulation of Off-Site Melter Runs ….............................. 33

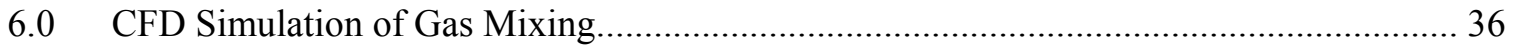

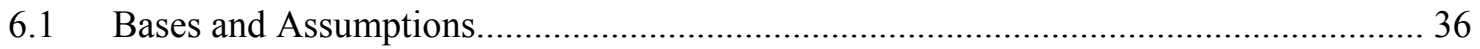

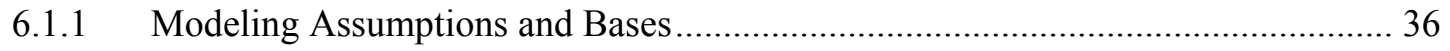

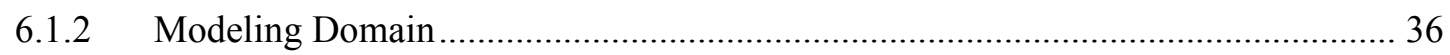

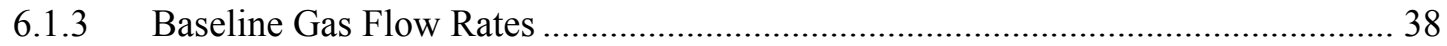

6.2 Governing Equations for Gas Species Transport in Turbulent Flow .............................. 39

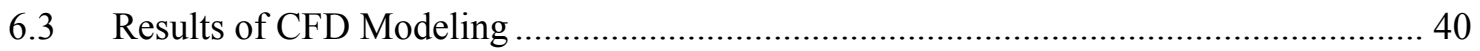

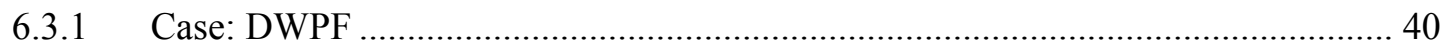

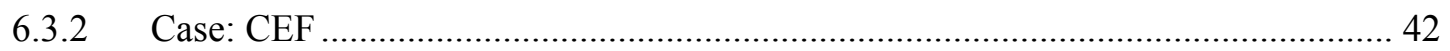

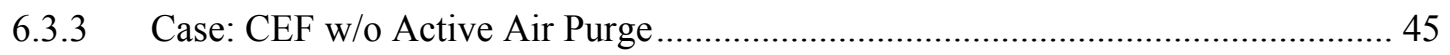

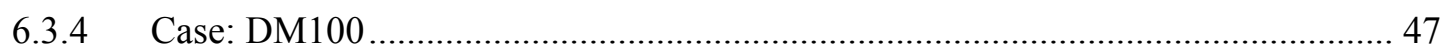

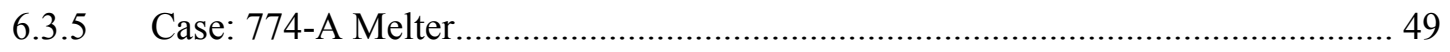

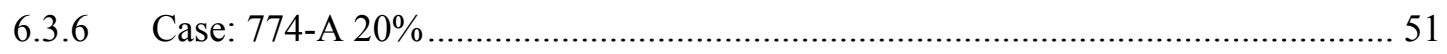

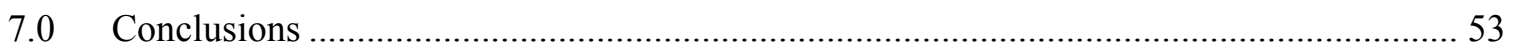

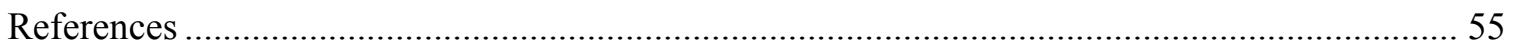




\section{LIST OF TABLES}

Table 3-1. Comparison of Melter Internal Design Parameters (Nominal). .................................... 4

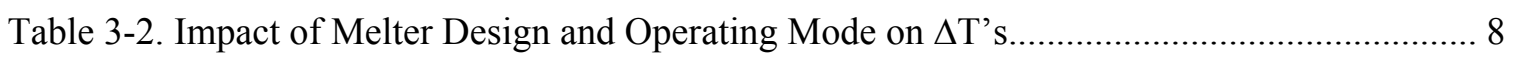

Table 4-1. 4-Stage Cold Cap Model Validation I: SCM-2 Sludge-only Run............................... 13

Table 4-2. 4-Stage Cold Cap Model Validation II: SCM-2 Precipitate Hydrolysis Run. ............. 14

Table 4-3. 4-Stage Cold Cap Model Validation III: 774-A Melter Run. ...................................... 15

Table 4-4. First-Order Global Kinetic Parameters for Vapor Space Oxidation. ........................... 15

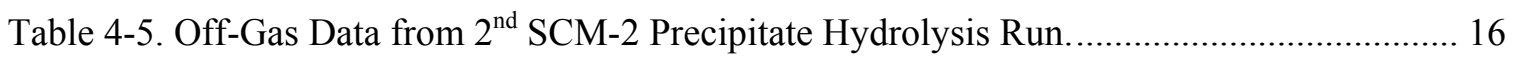

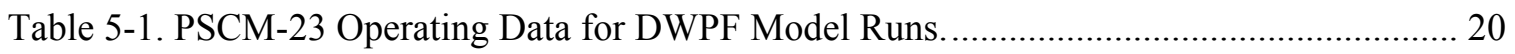

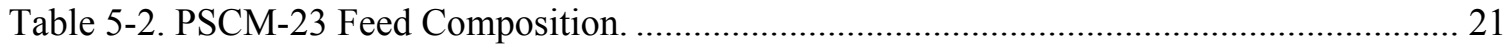

Table 5-3. Results of DWPF Model Runs to Simulate PSCM-23 Run....................................... 21

Table 5-4. RSM-LHH Operating Data for DWPF Model Runs................................................. 23

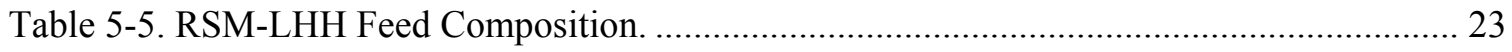

Table 5-6. Results of DWPF Model Runs to Simulate RSM-LHH Run...................................... 24

Table 5-7. RSM-MHH Operating Data for DWPF Model Runs................................................ 25

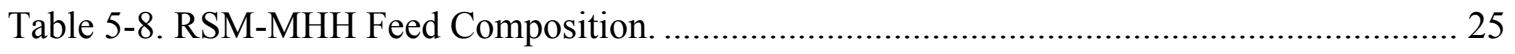

Table 5-9. Results of DWPF Model Runs to Simulate RSM-MHH Run.................................... 26

Table 5-10. DM10-A2 Operating Data for DWPF Model Runs. ................................................ 27

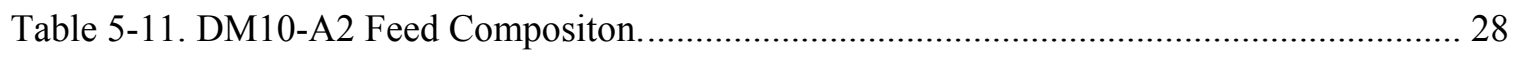

Table 5-12. Results of DWPF Model Runs to Simulate DM10-A2 Run. ...................................... 28

Table 5-13. DM10-SB6 Operating Data for DWPF Model Runs................................................. 29

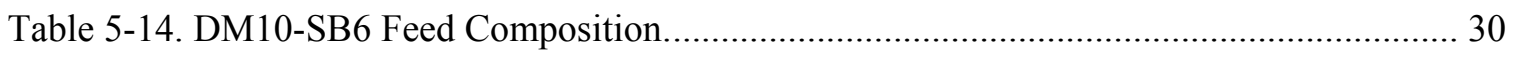

Table 5-15. Results of DWPF Model Runs to Simulate DM10-SB6 Run. .................................. 31

Table 5-16. DM100-A2 Operating Data for DWPF Model Runs.............................................. 31

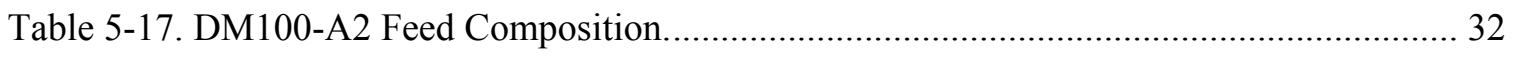

Table 5-18. Results of DWPF Model Runs to Simulate DM100-A2 Run. ................................... 33

Table 5-19. Summary of DWPF Model Predictions vs. Data. ..................................................... 34

Table 6-1. Gas Flow Rates at $100^{\circ} \mathrm{C}$ and 1 Bar Used in the CFD Modeling. .............................. 38 


\section{LIST OF FIGURES}

Figure 3-1. Comparison of Cross-Sections of the DWPF, CEF and DM100 Melters.................... 6

Figure 3-2. Comparison of IDMS and SCM-2 Internal Dimensions........................................... 9

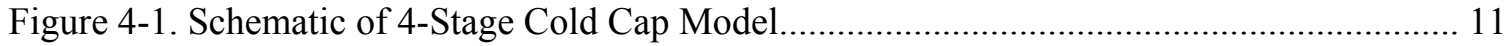

Figure 4-2. Calculated Concentration Profiles of $\mathrm{CO}$ and $\mathrm{H}_{2}$ vs. SCM-2 Data........................... 17

Figure 4-3. Calculated vs. Measured $\mathrm{H}_{2}$ Concentrations during 774-A Melter Run..................... 18

Figure 4-4. Calculated vs. Measured CO Concentrations during 774-A Melter Run................... 18

Figure 6-1. Geometric Configurations of CFD Modeling Domain............................................. 37

Figure 6-2. Vertical Center-Cut Vector Plot of Gas Velocities in ft/sec (Case: DWPF). ............. 41

Figure 6-3. Center-Cut Views of Gas Mixing in Mass Fractions (Case: DWPF)........................ 42

Figure 6-4. Vertical Center-Cut Vector Plot of Gas Velocities in $\mathrm{ft} / \mathrm{sec}$ (Case: CEF)................. 43

Figure 6-5. Center-Cut Views of Gas Mixing in Mass Fractions (Case: CEF)........................... 44

Figure 6-6. Vertical Center-Cut Vector Plot of Gas Velocities in $\mathrm{ft} / \mathrm{sec} \quad$ (Case:

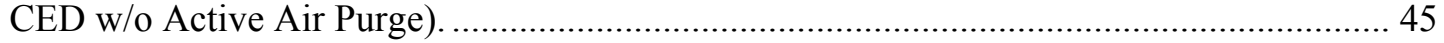

Figure 6-7. Center-Cut Views of Gas Mixing in Mass Fractions ICase:

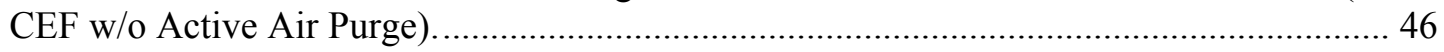

Figure 6-8. Vertical Center-Cut Vector Plot of Gas Velocities in ft/sec (Case: DM100)............ 47

Figure 6-9. Center-Cut Views of Gas Mixing in Mass Fractions (Case: DM100)....................... 48

Figure 6-10. Vertical Center-Cut Vector Plot of Gas Velocities in ft/sec (Case: 774-A Melter).. 49

Figure 6-11. Center-Cut Views of Gas Mixing in Mass Fractions (Case: 774-A Melter). ........... 50

Figure 6-12. Vertical Center-Cut Vector Plot of Gas Velocities in ft/sec (Case: 774-A 20\%).... 51

Figure 6-13. Center-Cut Views of Gas Mixing in Mass Fractions (Case: 774-A 20\%)............... 52 


\section{LIST OF ABBREVIATIONS}

\begin{tabular}{|c|c|}
\hline $\mathrm{AD}$ & Analytical Development \\
\hline $\mathrm{CEF}$ & Cold Cap Evaluation Furnace \\
\hline CFD & Computational Fluid Dynamics \\
\hline $\mathrm{CPC}$ & Chemical Processing Cell \\
\hline CSTR & Continuously-Stirred Tank Reactor \\
\hline DOE & Department of Energy \\
\hline DM10 & DuraMelter 10 \\
\hline DM100 & DuraMelter 100 \\
\hline DM1200 & DuraMelter 1200 \\
\hline DWPF & Defense Waste Processing Facility \\
\hline HEME & High Efficiency Mist Eliminator \\
\hline HLW & High Level Waste \\
\hline IC & Ion Chromatography \\
\hline $\mathrm{ICP}$ & Invariant Condensed Phase \\
\hline IDMS & Integrated DWPF Melter System \\
\hline LAW & Low Activity Waste \\
\hline LFL & Lower Flammability Limit \\
\hline MOG & Melter Off-Gas \\
\hline MCU & Modular Caustic-side Solvent Extraction Unit \\
\hline PBA & Phenylboric Acid \\
\hline PNNL & Pacific Northwest National Laboratory \\
\hline PSAL & Process Science Analytical Laboratory \\
\hline PSCM & Pilot Scale Ceramic Melter \\
\hline RSM & Research Scale Melter \\
\hline SCM-2 & Small Cylindrical Melter-2 \\
\hline SGM & Scale Glass Melter \\
\hline SRAT & Sludge Receipt and Adjustment Tank \\
\hline SRNL & Savannah River National Laboratory \\
\hline SBS & Submerged Bed Scrubber \\
\hline SME & Slurry-Mix Evaporator \\
\hline SRS & Savannah River Site \\
\hline TOC & Total Organic Carbon \\
\hline TSR & Technical Safety Requirements \\
\hline VSL & Vitreous State Laboratory \\
\hline WESP & Wet Electrostatic Precipitator \\
\hline $\mathrm{w} / \mathrm{o}$ & "without" \\
\hline WTP & Waste Treatment Plant \\
\hline
\end{tabular}




\subsection{Introduction}

The Defense Waste Processing Facility (DWPF) at the Department of Energy's (DOE) Savannah River Site (SRS) is planning a major flowsheet change to replace formic acid with glycolic acid as the baseline reductant for adjusting the high-level waste (HLW) feed for the melter. ${ }^{1}$ One of the flowsheet demonstration tests to be performed prior to implementation involves feeding the glycolic acid process feed to a pilot-scale melter and characterizing its off-gas to establish the technical bases for the melter off-gas flammability analysis. In addition, the surging potential of the new flowsheet feed in terms of both condensable and non-condensable off-gas flows needs to be quantified during the test in order to define the baseline melter transient for the safety analysis of the glycolic-acid flowsheet feed. The melter off-gas flammability assessment performed earlier in support of the down-select process indicated that a significant fraction of glycolic acid added might remain undissociated and volatilize upon entering the melter, ending up in the condensate recycle to the Tank Farms. ${ }^{2}$ Hence, it is also of vital importance to analyze the off-gas condensate produced during the test for the presence of glycolate or any other organic species that may pose operational difficulties on the downstream processes.

The DWPF melter feed contains several nonvolatile organic carbon species that decompose in the cold cap and produce flammable gases. For the new glycolic-acid flowsheet, the most abundant carbon source will be glycolate $\left(\mathrm{CH}_{2} \mathrm{OHCOO}^{-}\right)$which has the $\mathrm{H} / \mathrm{C}$ molar ratio of 1.5 compared to 1.0 for the formate $\left(\mathrm{COOH}^{-}\right)$. The second and third carbon sources are coal and oxalate $\left(\mathrm{C}_{2} \mathrm{O}_{4}{ }^{2-}\right)$ but their $\mathrm{H} / \mathrm{C}$ molar ratios are effectively zero, if coal is assumed to be $100 \%$ carbon. The fourth carbon source is Antifoam IIT-747 added during the Chemical Processing Cell (CPC) operation. Antifoam IIT-747 is not a pure compound and the $\mathrm{H} / \mathrm{C}$ molar ratio of its most abundant chemical form is 2.3 , which means that theoretically, Antifoam IIT-747 could lead to a 50\% higher off-gas flammability potential than glycolate per molar carbon basis. The fifth carbon source is entrained solvent in the strip effluent from the Modular Caustic-side Solvent Extraction Unit (MCU). The nonvolatile portion of the solvent currently being used in the MCU is projected to have the $\mathrm{H} / \mathrm{C}$ molar ratio of 1.4 .

The melter feed may also contain volatile organic carbon species including undissociated glycolic acid, whose $\mathrm{H} / \mathrm{C}$ molar ratio is 2 . Upon entering the melter, the volatile feed components flash off without participating in the cold cap reactions and may decompose into flammable gases in the vapor space of the melter. The flammability potential of the melter off-gas is then determined by how well the flammable gases produced from both volatile and nonvolatile feed components are combusted at a given melter vapor space temperature and air purge.

Two computer models have been in use since the radioactive startup in 1996 to quantitatively describe the cold cap chemistry and vapor space combustion and to further define the operating window for the DWPF melter in terms of feed interlocks and Technical Safety Requirements (TSR) ${ }^{3-5}$ The first model, called the 4-stage cold cap model, thermodynamically describes the chemistry of calcination and fusion reactions and calculates the compositions of both calcine gases and glass from a given feed composition. The calculated composition of calcine gases is then used as the input to the second model, called the melter off-gas (MOG) dynamics model, which predicts the transient behavior of the DWPF melter off-gas system under various upset scenarios. Embedded in the MOG dynamics model is the vapor space combustion module that calculates the time-dependent concentrations of flammable gases in the melter exhaust using a global kinetics scheme to enable the evaluation of the off-gas flammability potential downstream under a given transient. The baseline upset scenario for the MOG flammability safety analysis is the off-gas surge, which depends on the feed chemistry as well as the mode of melter operation. ${ }^{6}$ 
It is critically important to understand that the global kinetics scheme used in the DWPF melter combustion model is not just concerned with the intrinsic kinetics of $\mathrm{CO}$ and $\mathrm{H}_{2}$ oxidation only. Instead, it is based on the global combustion kinetic parameters that incorporate the effects of fluid mixing and heat transfer in the melter vapor space as well as intrinsic kinetics, and the fluid mixing and heat transfer are both greatly influenced by the design of melter internals such as configuration of the melter cavity and vapor space heaters. The data needed to derive the global kinetic parameters used in the current DWPF combustion model were obtained during the Scale Glass Melter (SGM) Run 9 with the formic-acid flowsheet feed. ${ }^{7}$ The SGM was a $1 / 2$ scale DWPF melter based on melt surface area or $2 / 3$ on a linear scale; the SGM had a 4-feet diameter melt surface compared to 6-feet for the DWPF melter, and the configuration of the air purge and offgas exhaust ports as well as the vapor space heaters were the same in both melters. Thus, the SGM was a large prototypic melter, and its cold cap behavior as well as the mode of fluid mixing and heat transfer in the vapor space were similar to those of the DWPF melter.

Furthermore, data from pilot- and full-scale melter runs have shown that with comparable feed chemistry off-gas surging potential generally increases with increasing melter size. Therefore, it would be desirable to obtain the baseline off-gas surge data for the glycolic-acid flowsheet feed using a melter that has as prototypic melter internals and as large a melt surface as practically possible, since the scale-up of data obtained from a smaller, non-prototypic melter will be much more challenging, if not impossible. Therefore, the goal of this study was to show explicitly the impact of melter internal design on the off-gas flammability by checking how well or how poorly the existing DWPF models would predict available off-gas data obtained from the melters with varying internal designs preferably using feeds based on the formic-acid reductant. The impact of melter internal design on the fluid mixing and, to a lesser extent, heat transfer was investigated further by performing computational fluid dynamics (CFD) modeling. This report summarizes the results of these model runs and the findings from the comparison of model results to data.

\subsection{Approach}

The task proceeded in the following sequence:

A. Survey the literature for available off-gas data, particularly $\mathrm{H}_{2}$ and $\mathrm{CO}$, from slurry-fed melter runs with either HLW or Low-Activity Waste (LAW) feed simulants preferably using formic acid as the baseline reductant.

B. Obtain melter internal design data for those melter runs with desired off-gas data.

C. Develop melter feed compositions from batching data for those selected melter runs.

D. Run existing DWPF 4-stage cold cap and vapor space combustion models using each feed composition as the input and calculate corresponding melter off-gas compositions.

E. Perform mass and energy balance calculations to estimate either missing or immeasurable data such as air inleakage and vapor space gas temperature for each selected melter run.

F. Compare calculated off-gas compositions to measured data, particularly $\mathrm{H}_{2}$ and $\mathrm{CO}$.

G. Build CFD models of vapor space gas mixing for various melter internal designs. 
H. Assess the impact of melter internal design on off-gas flammability based on the results of both DWPF and CFD model runs.

\subsection{Comparison of Melter Internal Designs}

Some of the design characteristics of the melters whose off-gas has been sampled for flammable gases are compared to those of the DWPF melter in Table 3-1. The SGM, Cold-cap Evaluation Furnace (CEF), and Research Scale Melter (RSM) at the Pacific Northwest National Laboratory (PNNL) all have a cylindrical cavity as does the DWPF melter, whereas the Pilot-Scale Ceramic Melter (PSCM) also at the PNNL has a rectangular cavity partitioned at a ratio of 40:60 between the melt pool and the vapor space, respectively, at nominal glass level. The CEF is a $1 / 12^{\text {th }}$ DWPF scale melter based on melt surface area and was used in 2010 to quantify the impact of glass bubblers on the intensity and duration of off-gas surges. ${ }^{6}$ One common design feature shared by these melters is that they all have the same cross-section throughout the cavity; therefore, their vapor space-to-melt pool cross-sectional area ratios are 1.

The vapor space of the DWPF melter is lined with three Mullfrax ${ }^{\circledR}$ block sections with decreasing thickness so that the uppermost section of the vapor space walls becomes flush with the Mullfrax lid which is designed to be thinner than the Monofrax K-3 refractory walls of the melt pool due to weight considerations. Thus, the diameter of the DWPF melter vapor space is the same as that of the melt pool (6') at the melt surface and increases to 6'4" and 6'8" in the middle and upper sections of the vapor space, respectively, as shown in Figure 3-1a. The vapor space-to-melt pool cross-sectional area ratio of 1.1 given in Table 3-1 is based on the diameter of the midsection of the DWPF melter vapor space.

By contrast, the remaining four melters shown in Table 3-1 have uneven cavities in that the crosssectional areas of the vapor space and melt pool are different and the scale of difference increases going from left to right. The Small-Cylindrical Melter 2 (SCM-2) and both DM10 and DM100 melters at the Vitreous State Laboratory (VSL) have a rectangular melt pool attached to a larger rectangular vapor space, while the 774-A melter has an 8" diameter cylindrical melt pool attached to a larger rectangular vapor space. As shown in Figure 3-2b, the SCM-2 melt pool had the same length (front-to-back) as its vapor space but a narrower width, whereas both the length and width of the DM10 and DM100 melt pools are smaller than their vapor space counterparts.

\subsection{Impact of Melter Internal Design on Fluid Mixing}

The overall geometry of various melter cavities shown schematically in Table 3-1 may be characterized by the following design parameters: (1) vapor space-to-melt pool cross-sectional area ratio, (2) vapor space aspect ratio, and (3) melt pool aspect ratio. The vapor space-to-melt pool cross-sectional area ratio is deemed important from the fluid mixing standpoint, since it represents the relative degree to which steam and calcine gases either expand or are squeezed as they enter the vapor space. Assuming 100\% cold cap coverage, steam and calcine gases enter the vapor space more or less uniformly all across the melt surface. If the cross-sectional area ratio is greater than 1, gases will tend to spread out to fill the additional cross-sectional area of the vapor space. This expansion slows down the upward velocity of gases, resulting in reduced turbulence and thus a lower overall mixing efficiency of gases. The overall mixing efficiency is expected to become lower with increasing vapor space-to-melt pool cross-sectional area ratio, as gases will tend to spread out even more. On the other hand, if the vapor space-to-melt pool cross-sectional area ratio is less than 1, gases will be squeezed into a smaller cross-sectional area and the overall mixing efficiency should increase with subsequent increase in turbulence. The validity of this postulation was checked by CFD modeling, as shown later in this report. 
Table 3-1. Comparison of Melter Internal Design Parameters (Nominal).

\begin{tabular}{|c|c|c|c|c|c|c|c|c|c|}
\hline & DWPF & SGM & CEF & RSM & PSCM & SCM-2 & 774-A & DM100 & DM10 \\
\hline \multicolumn{10}{|l|}{$\begin{array}{l}\text { Overall Geometry of } \\
\text { Melt Pool \& Vapor Space }\end{array}$} \\
\hline $\begin{array}{l}\text { Vapor Space-to-Melt Pool } \\
\text { Cross-sectional Area Ratio }\end{array}$ & 1.1 & 1.0 & 1.0 & 1.0 & 1.0 & 2.2 & 2.9 & 3.3 & 5.8 \\
\hline Vapor Space Aspect Ratio & 1.9 & 1.3 & 0.9 & 0.6 & 1.6 & 0.8 & 2.4 & 1.5 & 2.6 \\
\hline Melt Pool Aspect Ratio & 2.1 & 2.0 & 2.2 & 2.0 & 2.6 & 1.5 & 1.3 & 0.8 & 0.8 \\
\hline Melt Surface Area ${ }^{\#}\left(\mathrm{ft}^{2}\right)$ & 28.3 & 12.6 & 2.3 & 0.2 & 8.2 & 1.0 & 0.35 & 1.2 & 0.2 \\
\hline Melt Surface Area (x DWPF) & 1 & $1 / 2$ & $1 / 12$ & $1 / 140$ & $1 / 3$ & $1 / 28$ & $1 / 80$ & $1 / 24$ & $1 / 140$ \\
\hline Air Purge into Vapor Space & Yes & Yes & No & No & No & Yes & Yes & No & No \\
\hline Gas Residence Time (sec) & 7 & 7 & 4 & $1.4 *$ & 5 & 4 & 2.5 & 5 & 4 \\
\hline Glass Pouring & $\mathrm{DP} * *$ & DP & Overflow & Overflow & Air-lift & DP & $\begin{array}{c}\text { Tilt/ } \\
\text { Overflow }\end{array}$ & Air-lift & Air-lift \\
\hline Vapor Space Heaters & Yes & Yes & Yes & No & No & Yes & Yes & Yes & Yes \\
\hline
\end{tabular}

\# Including hardware. ${ }^{*}$ Calculated value for RSM-MHH run. $* * \mathrm{DP}=$ Differential pressure. 
Also shown in Table 3-1 are the aspect ratios defined as the diameter (or equivalent diameter if the cross-section is not circular) divided by the height of the melt pool or vapor space. It should be noted that the small vapor space within the melt cavity not occupied by the glass in the SCM-2, 774-A, DM10 and DM100 melters was excluded from the aspect ratio calculations. It is shown that the melt pool aspect ratios for the melters with a uniform cross-section cavity are 2 or greater, while for those melters with a non-uniform cross-section cavity the ratios are less than 2. It is also shown that the DM10 and DM100 melters not only have the two largest vapor space-to-melt pool cross-sectional area ratios at 5.8 and 3.3, respectively, but also have the smallest melt pool aspect ratio of all the melters considered in this study at 0.8 . The impact of the melt pool aspect ratio on the cold cap and melt pool chemistry is expected to be subtle for non-bubbled operation. For bubbled operation, however, its impact is expected to be significant particularly on the interfacial mass transfer between the bubble and melt phases, since for the same bubbling rate per unit melt surface area bubbles will rise longer in the melt pool with a smaller aspect ratio. Furthermore, at high bubbling rates, the potential for bubble coalescence is also greater in the melt pool with a smaller aspect ratio, thus disrupting a greater area of the cold cap when they burst at the surface.

Likewise, a vapor space with a smaller aspect ratio is taller relative to its diameter so that with the feed and air purge rates scaled properly steam and calcine gases will travel longer to the exit port located at the top and therefore have more time to mix with air than in a larger aspect-ratio vapor space. In this sense, with the aspect ratio of 0.9 the overall mixing efficiency in the CEF vapor space is expected to be higher than that in the DWPF melter vapor space whose aspect ratio is 1.9. It is, however, noted in Table 3-1 that the actual gas residence time of the CEF is shorter than that of the DWPF melter; 4 vs. 7 seconds. This is in part due to the fact that during the 2010 CEF run the feed rate was pushed above $1 / 12^{\text {th }}$ of the DWPF rate in an effort to induce off-gas surging, while its air inleakage rate was also higher. It is also noted that the CEF vapor space aspect ratio was purposely set at $1 / 2$ that of the DWPF melter to reduce the likelihood of premature clogging of the off-gas line in anticipation of increased particulate entrainment with the bubblers in operation.

Thus, it is clear that as long as the flow rates are properly scaled, vapor space aspect ratio and gas residence time are inversely proportional. Moreover, the impact of varying gas residence time on the overall combustion efficiency as a result of varying vapor space aspect ratio is attributed more to allowing more or less time for the gases to get heated up for higher or lower combustion kinetics, respectively, rather than allowing more or less time for the gases to mix. This is because the overall mixing efficiency is likely to be determined largely by the vapor space-to-melt pool cross-sectional area ratio, since it sets the overall convective flow pattern within the vapor space; therefore, having a taller vapor space is like stretching a given overall convective flow profile vertically, while allowing some degree of smaller-scale mixing along the stretched profile.

To illustrate the differences in melter cavity design in greater detail, the cross-sections of the $1 / 12^{\text {th }}$ scale CEF and $1 / 24^{\text {th }}$ scale DM100 (based on melt surface area) are compared in Figure 3-1 to that of the DWPF melter. First, the cylindrical cavities of the DWPF melter and CEF have the same or nearly the same diameter from the top to bottom of each melter and therefore their vapor space-to-melt pool cross-sectional area ratios are equal or close to 1. On the other hand, the DM100 has rectangular cavities for both the vapor space and the melt pool, and the crosssectional area of its vapor space is 3.3 times larger than that of the melt pool. The DM100 melt cavity is $\sim 28$ " high and, after subtracting the nominal glass height of 19" (nominal melt line is indicated by the dotted line at the center of Figure 3-1c), the remaining 9" of the upper melt cavity becomes a secondary vapor space for the cold cap gases before they expand into the main vapor space. There is no such secondary vapor space in either the DWPF melter or CEF that complicates the overall geometry of the vapor space and thus the pattern of gas mixing. 


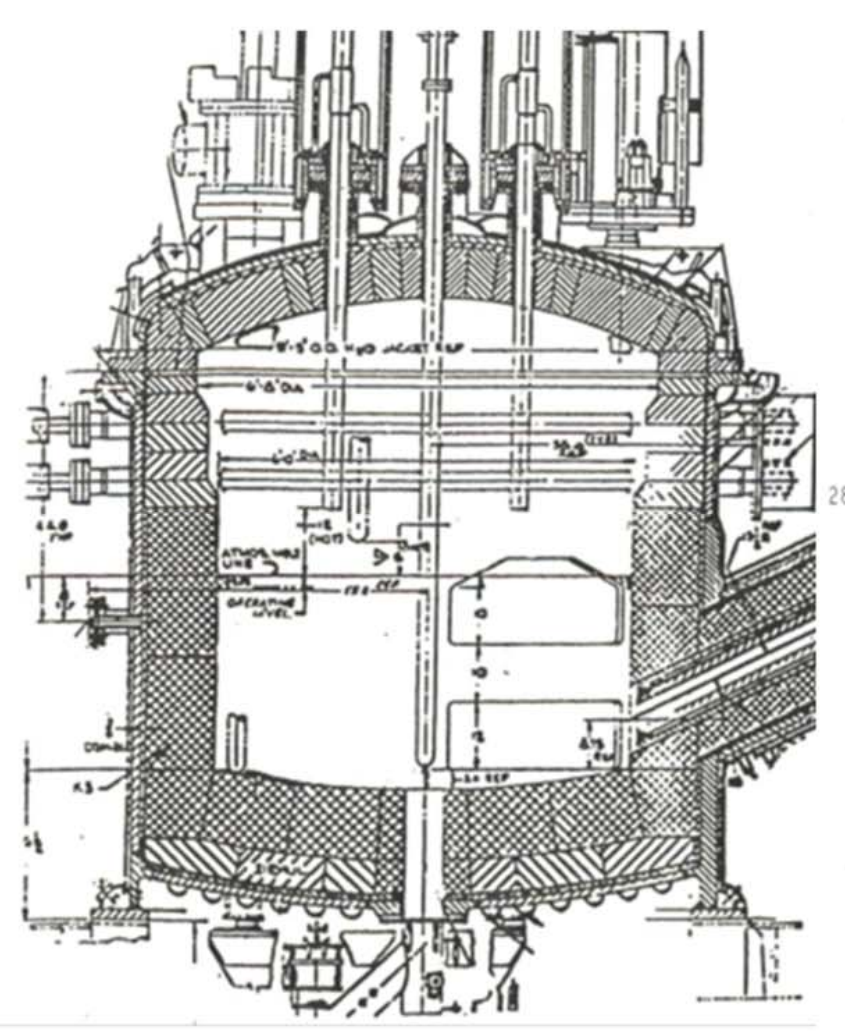

(a) Cross-section of the DWPF Melter showing two of the eight Vapor Space Heaters.

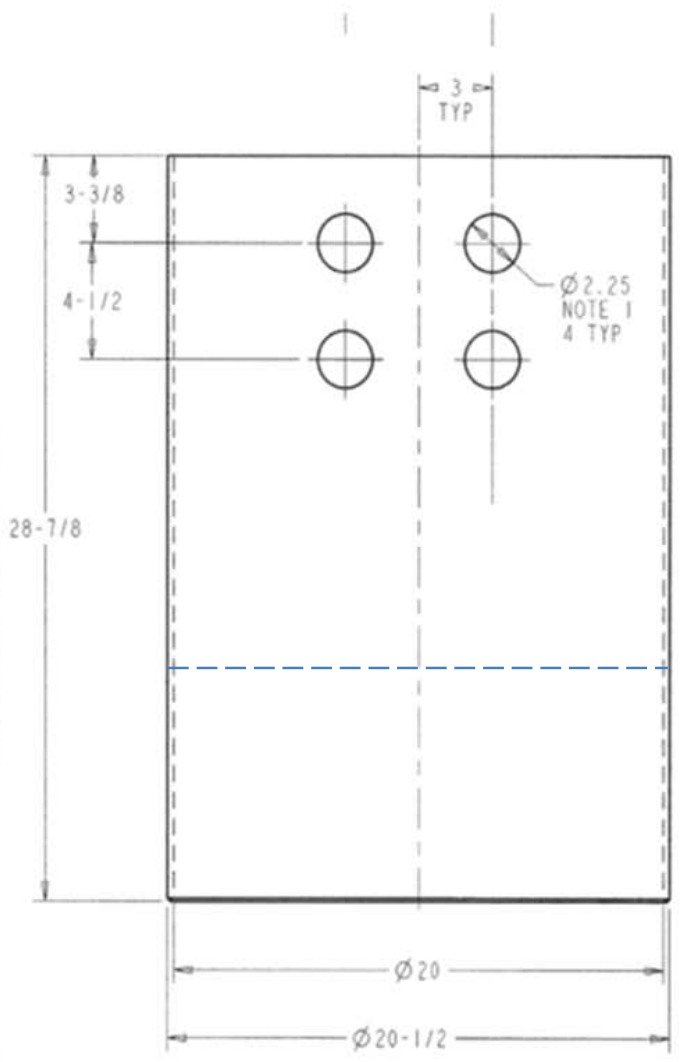

(b) Schematic of the CEF Melter Cavity showing four Vapor Space Heaters.

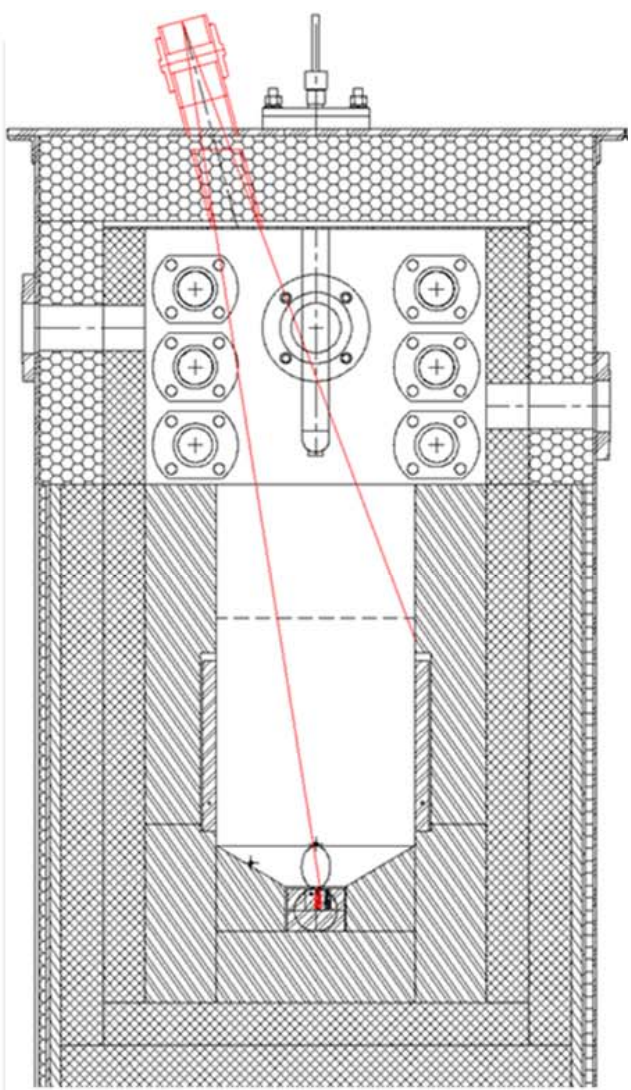

(c) Cross-Section of the DM100-WV Melter showing six Vapor Space Heaters. ${ }^{9}$

Figure 3-1. Comparison of Cross-Sections of the DWPF, CEF and DM100 Melters. 


\subsection{Impact of Melter Internal Design on Heat Transfer}

The first-principle combustion modeling requires that the actual gas temperature profile be known under the prevailing thermal conditions of the melter vapor space where radiation is the dominant mode of heat transfer. Unlike most solid bodies, many gases such as $\mathrm{N}_{2}$ and $\mathrm{O}_{2}$ are essentially transparent to radiation. When they absorb and emit radiation to an appreciable extent like $\mathrm{CO}_{2}$ and water vapor, they do so only in certain narrow wavelength bands at rates that vary with the wavelength band, ${ }^{8}$ which makes the radiation transfer analysis very complex even for a simple system involving just one gas medium and one solid surface. At the same time, gases are also heated by convection at the surfaces of the vapor space heaters and the refractory walls, and the temperature of the latter is in turn determined by the radiative heat exchange among all the solid surfaces of the vapor space including the cold cap and the exposed melt surface. Based on this complicated picture of thermal events taking place inside the melter vapor space, the following statements can be made:

First, the design of melter cavity influences the gas temperature profile in the vapor space to a great extent, since it not only provides the solid surfaces for radiative and convective heat transfer but sets how those surfaces are configured in relation to one another, thus affecting the view factor calculations. The design of melter cavity also influences how much of the heat emitted by the vapor space heaters actually reaches the cold cap and is subsequently used to volatilize free water in the feed and superheat the resulting steam. Specifically, the partition of the vapor space heat is largely determined by the vapor space-to-melt pool cross-sectional area ratio; the larger the ratio, the more radiant surfaces the cold cap will see and thus receives more energy.

Second, the vapor space gas temperature profile must be calculated by simultaneously solving the momentum, heat and component mass balance equations of a reacting flow, which is exceedingly difficult to do, if not impossible, for a number of reasons other than having to deal with radiative heat transfer such as the complex geometry of the vapor space internals, a large number of gas and particulate species involved, and the hard-to-even-define boundary conditions at the cold cap that has a highly complex and dynamic spatial domain. Therefore, the DWPF melter combustion model instead relies on the global kinetics parameters into which the effects of intrinsic kinetics, fluid mixing and heat transfer are lumped at one representative gas temperature. Clearly, in order for this global kinetics approach to work, these parameters must be derived from the data taken from as prototypic a melter as practically possible in order to simulate the conditions of the DWPF melter closely.

Both radiative and convective heat transfer is also influenced by the configuration of the heat source, i.e., vapor space heaters. As an illustration, Figure 3-1 shows that the configuration of the DM100 vapor space heaters (shown by the six flanges with the '+' symbol in the middle) is quite different from that of the DWPF or CEF vapor space heaters; they are positioned close to the refractory walls and spread out vertically traversing practically the entire vapor space height. On the other hand, the DWPF and CEF melter vapor space heaters are positioned more toward the center and vertically confined to the mid to upper sections of the vapor space. Again, it is these horizontally-entering vapor space heaters that provide much of the energy required to boil off water in the feed and further superheat the steam and calcine gases both directly and indirectly through the radiant heat reflected off all exposed surfaces. Thus, it is expected that the differences in the geometry of melter cavity and the arrangement of vapor space heaters will make the fluid mixing and heat transfer characteristics of the DM100 melter different from those of the DWPF melter and CEF. 


\subsection{Impact of Melter Internal Design on $\Delta \mathrm{T}$}

The global kinetics approach requires a single representative gas temperature for the vapor space. It is, however, difficult to measure the gas temperature without the interference of radiation shine from the vapor space heaters, refractory walls and the open melt surface. Even if it were possible to eliminate the interference of radiation, it would still be difficult to determine the representative gas temperature, since readings would vary with the location in the vapor space. Currently, the DWPF melter vapor space temperature is measured inside the thermowells, while the temperature of the off-gas exiting the melter is calculated from the mass and energy balance around the film cooler and subsequently taken as the representative gas temperature at which to evaluate the global kinetic parameters. Since gases have low or negligible absorptivity compared to most solids, calculated gas temperatures are lower than those measured and, as expected, the difference between measured and calculated vapor space gas temperatures $(\Delta T)$ tend to vary depending on the melter internal design and mode of operation, as shown in Table 3-2.

It is noted that the SCM-2 vapor space gas temperatures were calculated by performing an energy balance around a differential fluid volume in the vapor space assuming complete radial mixing, ${ }^{10}$ and the resulting $\Delta \mathrm{T}$ 's averaged 246 and $445^{\circ} \mathrm{C}$ during feeding and idling, respectively. The $\Delta \mathrm{T}$ 's were greater during idling than during feeding for two main reasons; (1) the exposed melt surface emits more intense radiation than the vapor space heaters, and (2) $\mathrm{N}_{2}$ and $\mathrm{O}_{2}$ that constitute the vapor space gases during idling are transparent to radiation. The Integrated DWPF Melter System (IDMS) had a vapor space-to-melt pool cross-sectional area ratio of 4 but, unlike the SCM-2 or DM100, the 4X expansion from the melt surface to the vapor space was tapered, as shown in Figure 3-2. The gas temperature in the IDMS vapor space was calculated from the mass and energy balance around the film cooler, and the calculated gas temperatures were $190-280^{\circ} \mathrm{C}$ lower than the measured temperatures that ranged from 630 to $830^{\circ} \mathrm{C}$ while feeding the coupled feed. ${ }^{11}$

Table 3-2. Impact of Melter Design and Operating Mode on $\Delta T$ 's.

\begin{tabular}{|c|c|c|c|c|c|c|c|}
\hline $\begin{array}{l}\text { Melter } \\
\text { ID }\end{array}$ & Scale $^{+}$ & $\begin{array}{c}\text { Vapor Space } \\
\text { to } \\
\text { Melter Pool } \\
\text { Cross- } \\
\text { Sectional } \\
\text { Area Ratio }\end{array}$ & $\begin{array}{l}\text { Operating } \\
\text { Mode }\end{array}$ & $\begin{array}{c}\text { Measured } \\
\text { Vapor Space } \\
\text { Temperature } \\
\text { In Thermowell } \\
\left({ }^{\circ} \mathrm{C}\right)\end{array}$ & $\begin{array}{c}\text { Calculated } \\
\text { Vapor Space } \\
\text { Gas } \\
\text { Temperature } \\
\left({ }^{\circ} \mathrm{C}\right)\end{array}$ & $\begin{array}{l}\Delta \mathrm{T} \\
\left({ }^{\circ} \mathrm{C}\right)\end{array}$ & Ref. \\
\hline SCM-2 & $1 / 28$ & 2.2 & Feeding & $481-762$ & $248-487$ & $215-291$ & 10 \\
\hline "“ & “" & "“ & Idling & $803-880$ & $374-419$ & $429-461$ & 10 \\
\hline IDMS & $1 / 9$ & 4.0 & Feeding & $630-830$ & $440-550^{*}$ & $190-280$ & 11 \\
\hline “" & “" & "6 & Idling & $785-888$ & $440-583$ & $240-443$ & 11 \\
\hline SGM-9 & $1 / 2$ & 1.0 & Feeding & $570-705$ & $393-515$ & $177-190$ & 12 \\
\hline PSCM-5 & $1 / 3$ & $" 6$ & " & $492-581$ & $316-443$ & $138-198$ & 10 \\
\hline 774-A & $1 / 80$ & 2.9 & "6 & $725-850$ & $355-385^{*}$ & $370-465$ & 13 \\
\hline DWPF-1 & $1 / 1$ & 1.1 & 66 & $730-760$ & $574-569$ & $156-191$ & 14 \\
\hline DWPF-2 & $" 6$ & 6 & "“ & $614-645$ & $480-510$ & $125-149$ & 15 \\
\hline
\end{tabular}

Melt surface area ratio to that of DWPF melter. * Calculated using the correlation given in the reference. 


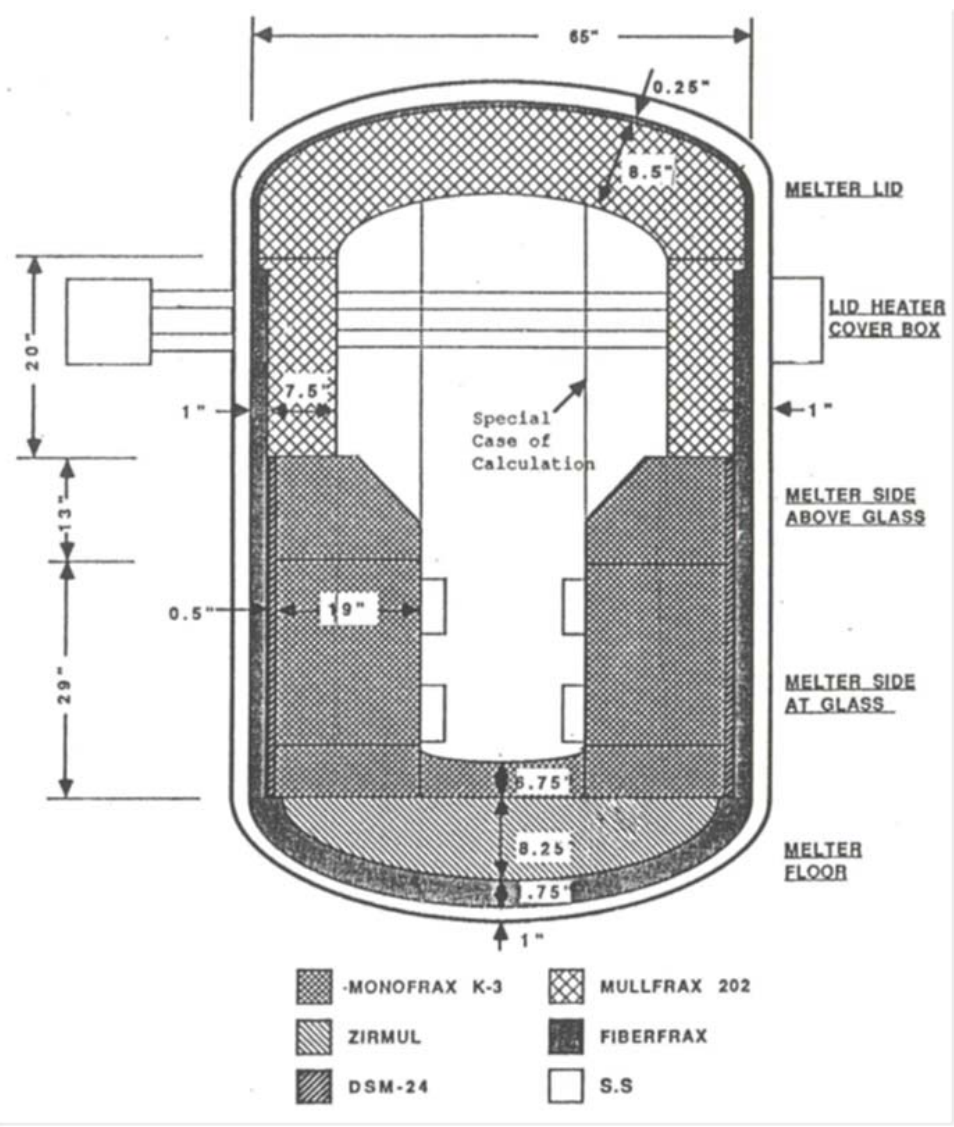

(a) IDMS

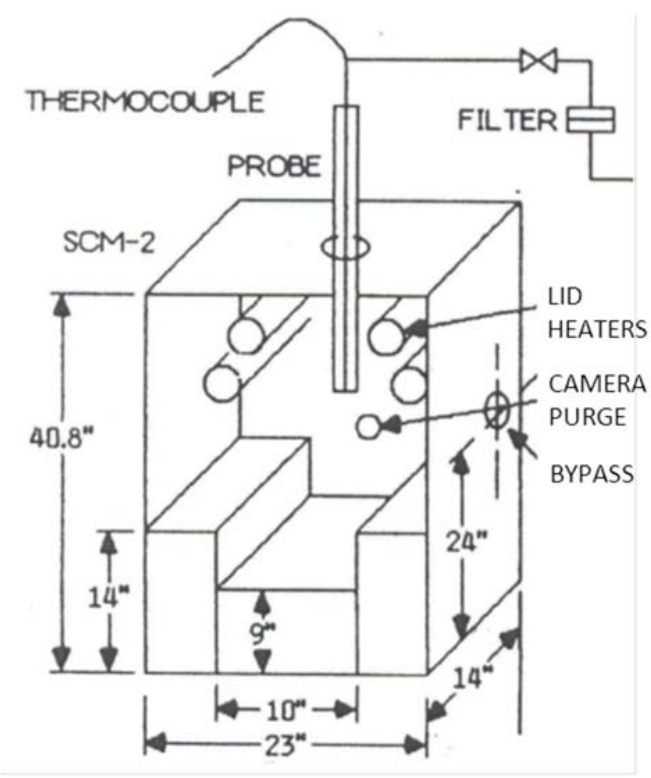

(Not-to-Scale)

(b) SCM-2

Figure 3-2. Comparison of IDMS and SCM-2 Internal Dimensions.

When the IDMS melter was idling, the calculated gas temperatures were 240 to $443^{\circ} \mathrm{C}$ lower than those measured. It is noted that the mean $\Delta \mathrm{T}$ of the IDMS were slightly lower than that of the SCM-2 during feeding, while the mean $\Delta \mathrm{T}$ of the former during idling was $\sim 100^{\circ} \mathrm{C}$ lower despite the fact that it had a $80 \%$ larger vapor space-to-melt pool surface area ratio than that of the SCM2. However, these observations seem to make sense considering the fact that due to its relatively tall height the SCM-2 vapor space still had a larger surface area for radiation at $17 \mathrm{ft}^{2}$ per $\mathrm{ft}^{2}$ of melt surface compared to $15 \mathrm{ft}^{2}$ per $\mathrm{ft}^{2}$ of the IDMS melt surface (Refer to Figure 3-2). Aside from the view factor considerations, it is the surface area of the refractory walls and lid that reflects the radiation shine from the melt surface during idling. In terms of the vapor space aspect ratio, the values for the IDMS ranged from 1.5 at the melt surface to 2.4 in the main vapor space, while that of the SCM-2 was only 0.8 .

Unlike the SCM-2 and IDMS melter, the vapor space-to-melt pool cross-sectional area ratio of the SGM was 1, which means that the surface area ratio of the SGM vapor space refractory walls and lid to its melt was lower than that of the SCM-2 or IDMS melter. As a result, the SGM vapor space thermowell would receive less radiation, and the difference between measured vapor space and true gas temperatures would be less in the SGM than in either the SCM-2 or IDMS melter. This was indeed the case, as shown in Table 3-2; the calculated $\Delta \mathrm{T}$ 's for the SGM ranged from 177 to $190^{\circ} \mathrm{C}$ compared to the mean $\Delta \mathrm{T}^{\prime}$ 's of 235 and $246^{\circ} \mathrm{C}$ for the IDMS melter and SCM-2, respectively. ${ }^{12}$ 
A series of PSCM runs were made in the early 1980's to help establish the design criteria for the DWPF melter off-gas system. The PSCM also had horizontal lid heaters with a cross-sectional area ratio of 1 like the SGM, and the gas temperatures were reported to be $138-198^{\circ} \mathrm{C}$ lower than those measured during Run $5 .{ }^{10}$ Although the details on how these $\Delta \mathrm{T}$ 's were calculated or even measured are not known, they appear to be comparable to those of the SGM, as expected.

The effect of reduced cold cap coverage on the gas temperature was seen clearly during the 774A melter runs. ${ }^{13}$ Since much of the energy required for heating the pour spout came from the vapor space heaters by conduction through the refractory, it was necessary to maintain the vapor space temperature above $725^{\circ} \mathrm{C}$ if feeding and pouring were to proceed continuously. As a result, the highest sustainable cold cap coverage during the 774 -A melter runs was only about $20 \%$ and, with the increased radiant heat flux from the exposed melt surface, the measured vapor space temperatures were $370-470^{\circ} \mathrm{C}$ higher than those calculated from the mass and energy balance around the film cooler. It is noted that these $\Delta \mathrm{T}$ 's are quite comparable to those observed during idling of the SCM-2 and IDMS.

Also shown are two sets of DWPF data collected more than 4 years apart. The first data set (DWPF-1) represents two steady state operations at 0.4 and 0.8 GPM feed rate during the Waste Qualification Runs in 1995. ${ }^{14}$ The second data set (DWPF-2) was collected during the sludge batch 2 (SB2) campaign and represents six steady state operations at feed rates ranging from 0.43 to 0.53 GPM between $11 / 29 / 99$ and $6 / 6 / 00 .{ }^{15}$ When the DWPF Melter 1 was relatively new in 1995, the differences between the measured and calculated vapor space gas temperatures were quite comparable to those of the SGM, which was expected based on the fact that both melters have the same cross-sectional area ratio of 1 . It is, however, noted that the mean $\Delta \mathrm{T}$ was reduced by $\sim 40^{\circ} \mathrm{C}$ in 2000 and this was due to the fact that the DWPF Melter 1 was running at $100^{\circ} \mathrm{C}$ or so cooler based on the measured vapor space temperature than it was in 1995 at comparable feed rates and dome heater powers, which was in turn caused by the increased air inleakage after 5 years of continued use.

\subsection{DWPF Models}

The chemistry of the HLW or LAW feeds to be vitrified is very complicated and the resulting offgas flammability depends not only on the feed chemistry but on the design and operating variables of the melters used. It is, therefore, inevitable that the DWPF models that are used to predict melter off-gas flammability and further set the operating window for the melter are built upon several simplifying assumptions. A brief description of each model is given next.

\subsection{Cold Cap Model}

The purpose of this model is to calculate the concentration of flammable gases produced from the calcination and fusion of the non-volatile feed components and the composition of the resulting glass that are internally consistent in terms of the overall oxygen balance.

\subsubsection{Bases and Assumptions}

It is assumed that all chemical species present in the cold cap are in thermodynamic equilibrium with one another, thus ignoring such effects as chemical kinetics and transport resistances within various phases that form among a very large number of waste components and glass-forming frit. To better represent the gradual nature of the melting process, the entire cold cap is modeled as a continuous, 4-stage countercurrent reactor, as shown in Figure 4-1. The gas and solids products are allowed to reach equilibrium in each stage, before the former is passed on to the next stage up, while the latter is passed on to the next stage down, thereby maintaining countercurrent gas-solids flows between stages. 
SRNL-STI-2012-00121

Revision 0

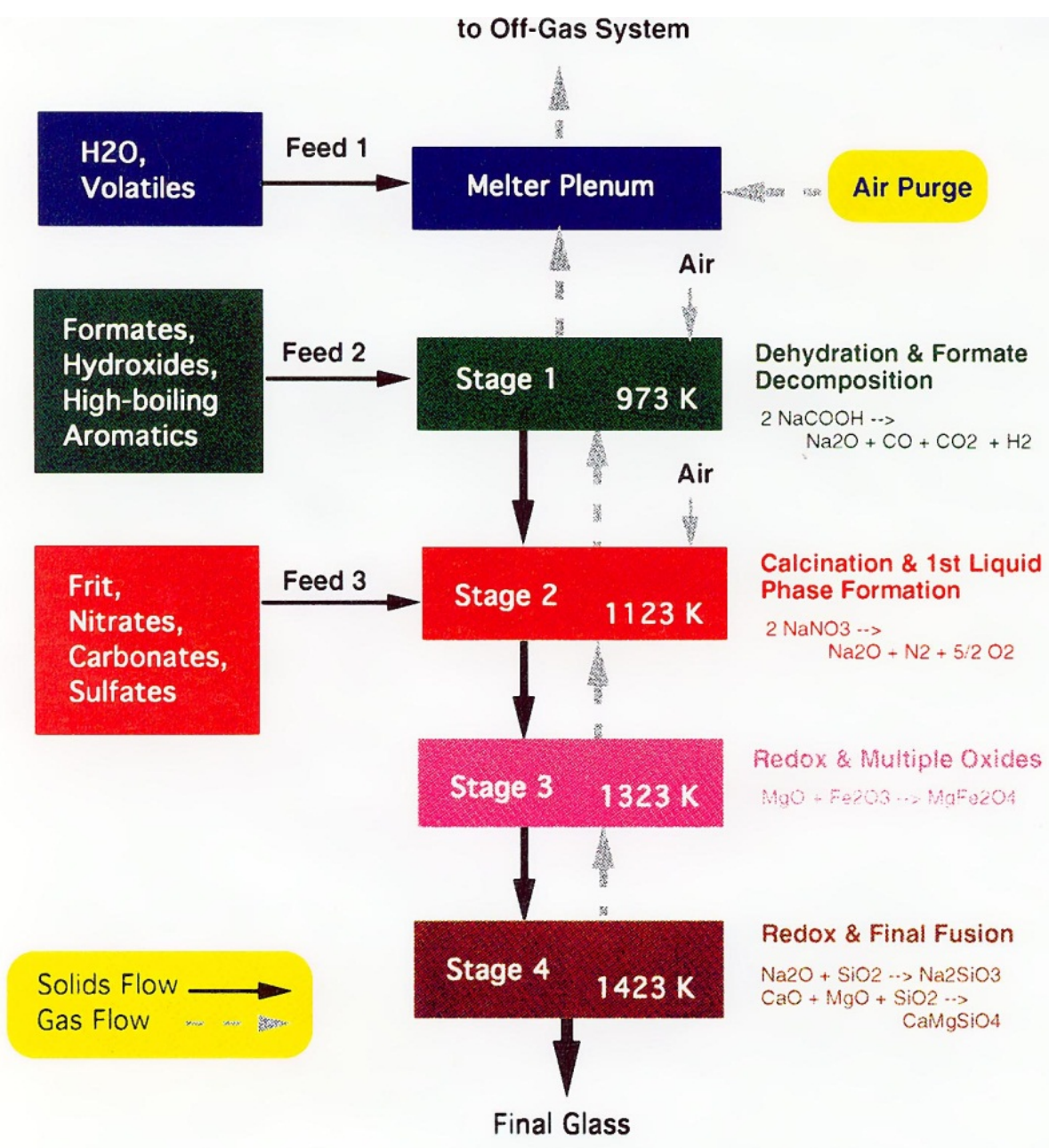

Figure 4-1. Schematic of 4-Stage Cold Cap Model.

The temperature of each stage is set progressively higher from $700^{\circ} \mathrm{C}$ at the top (Stage 1) to the final melt temperature of $1150^{\circ} \mathrm{C}$ at the bottom (Stage 4); therefore, Stage 4 actually represents the bulk melt pool. The temperature of Stage 1 was set based on the finding that the calculated molar ratio of $\mathrm{CO}$ to $\mathrm{CO}_{2}$ in the calcine gases at $700^{\circ} \mathrm{C}$ closely matched measured data. ${ }^{3}$ The volatile feed components such as free $\mathrm{H}_{2} \mathrm{O}$ and low-boiling organic species are assumed to boil off upon entering the melter and only the remaining non-volatile components enter the cold cap. Furthermore, hydroxides and most salt species except for the sulfates are pre-decomposed and fed as oxides and gaseous products such as water vapor as shown next:

$$
\text { Stage 1: } \begin{array}{ll}
2 \mathrm{Fe}(\mathrm{OH})_{3} \rightarrow \mathrm{Fe}_{2} \mathrm{O}_{3}+3 \mathrm{H}_{2} \mathrm{O} \\
& 2 \mathrm{NaCOOH} \rightarrow \mathrm{Na}_{2} \mathrm{C}_{2} \mathrm{O}_{4}+\mathrm{H}_{2} \\
& 2 \mathrm{NaNO}_{3} \rightarrow 2 \mathrm{NaNO}_{2}+\mathrm{O}_{2} \\
& 2 \mathrm{NaNO}_{2} \rightarrow \mathrm{Na}_{2} \mathrm{O}+\mathrm{N}_{2}+3 / 2 \mathrm{O}_{2} \\
& 2 \mathrm{NaNO}_{2} \rightarrow \mathrm{Na}_{2} \mathrm{O}+\mathrm{NO}+\mathrm{NO}_{2}
\end{array}
$$




$$
\text { Stage 2: } \quad \begin{aligned}
\mathrm{Na}_{2} \mathrm{C}_{2} \mathrm{O}_{4} & \rightarrow \mathrm{Na}_{2} \mathrm{CO}_{3}+\mathrm{CO} \\
\mathrm{Na}_{2} \mathrm{CO}_{3} & \rightarrow \mathrm{Na}_{2} \mathrm{O}+\mathrm{CO}_{2}
\end{aligned}
$$

Due to its low decomposition temperature, the formate is allowed to decompose into oxalate in Stage 1 via Reaction (2), thereby releasing $\mathrm{H}_{2}$ in the process. The oxalate thus formed and that already in the feed decompose into $\mathrm{CO}$ and $\mathrm{CO}_{2}$ with carbonate as the intermediate product in Stage 2, as shown in Reactions (6) and (7). The nitrate first decomposes into nitrite and $\mathrm{O}_{2}$ and the subsequent decomposition of nitrite via Reaction (4) or (5) is allowed to proceed through Stage 3. Under the prevailing temperatures of the cold cap, the formation of $\mathrm{N}_{2}$ and $\mathrm{O}_{2}$ is thermodynamically favored over $\mathrm{NO}$ or $\mathrm{NO}_{2}$. However, when the cold cap entity is in sufficient contact with air, e.g., due to a low cold cap coverage, the nitrite is forced to decompose exclusively by Reaction (5), thereby reducing the overall oxidizing potential of nitrate. ${ }^{16}$ Currently, the nitrate is fed to Stages 1, 2 and 3 at the 30:50:20 ratios, respectively.

In Stage 3, the spinels are allowed to form by combining two oxides at different oxidation states. For example, the nickel-iron spinels are formed by combining $\mathrm{Ni}(\mathrm{II}) \mathrm{O}$ and $\mathrm{Fe}(\mathrm{III})_{2} \mathrm{O}_{3}$ as shown by Reaction (8). Due to structural similarities, these spinels readily form solid solutions with one another and thus are assumed to form a separate phase of their own. Those species that do not form solid solutions with other species are included in the Invariant Condensed Phase (ICP), i.e., each ICP species forms a separate phase by itself. Therefore, as more species are included in the ICP, the total number of phases to be considered in the equilibrium calculations increases, thus making it more difficult to achieve convergence. Finally, the condensed products from Stage 3 are converted into the glass melt in Stage 4 by forming various silicate compounds, as shown by Reaction (9); the letter "l" after each species denotes "liquid."

$$
\begin{array}{ll}
\text { Stage 3: } & \mathrm{NiO}+\mathrm{Fe}_{2} \mathrm{O}_{3} \rightarrow \mathrm{NiFe}_{2} \mathrm{O}_{4} \\
\text { Stage 4: } & \mathrm{Na}_{2} \mathrm{Ol}+\mathrm{SiO}_{2} l \rightarrow \mathrm{Na}_{2} \mathrm{SiO}_{3} l
\end{array}
$$

\subsubsection{Validation of 4-Stage Cold Cap Model}

Since melter off-gas is typically sampled downstream of the film cooler, the melter vapor space must be cooled to a temperature low enough to freeze any combustion reactions that might occur so that the resulting off-gas would reflect the composition of the calcine gases exiting the cold cap. This is typically done by either turning off the vapor space heaters or injection of excess ambient air or both. The cold cap model was validated against three sets of data obtained using these methods of cooling the vapor space. The details of each validation run including the model input and output are given elsewhere, ${ }^{3}$ and only the key results of validation are highlighted here with a particular emphasis on the potential impact of melter internal design on the data.

The first set of data was taken during the $1^{\text {st }} \mathrm{SCM}-2$ precipitate hydrolysis run with the baseline sludge-only feed using no lid heat but with $\mathrm{N}_{2}$ purge. ${ }^{17}$ With the vapor space heaters turned off, the measured temperature dropped to $421{ }^{\circ} \mathrm{C}$, and the actual gas temperature would have been below $200^{\circ} \mathrm{C}$ according to the data given in Table 3-2. It was shown earlier that the combustion rates of $\mathrm{CO}$ and $\mathrm{H}_{2}$ slow down considerably at near $200^{\circ} \mathrm{C}$ so that their concentrations begin to level off, ${ }^{3}$ which means that the vapor space combustion can be effectively ignored at $421^{\circ} \mathrm{C}$ as measured in the thermowell. Any variations in the off-gas data can then be attributed to the differences in feed chemistry and/or potentially the design of melter internals, particularly that of the melt pool. 
The only design parameter listed for the melt pool in Table 3-1 is its aspect ratio, which is defined as the ratio of the equivalent diameter of the melt surface to the nominal melt depth. The aspect ratio of the SCM-2 melt pool was 1.5 compared to 2.1 for the DWPF melter. As stated above, however, it is not clear what the impact of the melt pool aspect ratio on the compositions of the calcine gases and glass would be during non-bubbled operation, just as the SCM-2 was operated. The iron redox ratio of glass and the $\mathrm{CO} / \mathrm{CO}_{2}$ ratio of the SCM-2 off-gas predicted by the 4-stage cold cap model are compared to data in Table 4-1. Since the feed contained no aromatic carbon species, the formate was the sole source for flammable gases. Furthermore, no $\mathrm{H}_{2}$ data were taken during the run, so the full validation of the model was not possible. Nevertheless, the agreement between predicted glass redox and $\mathrm{CO} / \mathrm{CO}_{2}$ ratio and data is seen to be good. Therefore, it seems reasonable to conclude that the $29 \%$ difference between the SCM-2 and DWPF melt pool aspect ratios may not have been significant enough to affect the data, if indeed there is such an impact by the aspect ratio.

Table 4-1. 4-Stage Cold Cap Model Validation I: SCM-2 Sludge-only Run.

\begin{tabular}{||l|c|c||}
\hline Molar Ratios & Data $^{17}$ & Model \\
\hline $\mathrm{Fe}^{2+} / \mathrm{Fe}^{3+}$ (glass) & $<0.22$ & 0.13 \\
\hline $\mathrm{CO} / \mathrm{CO}_{2}$ & 0.13 & 0.11 \\
\hline $\mathrm{H}_{2} /\left(\mathrm{CO}+\mathrm{CO}_{2}\right)$ & $\mathrm{n} / \mathrm{a}$ & 0.48 \\
\hline
\end{tabular}

The second set of data used for the validation was taken during the $2^{\text {nd }}$ SCM-2 precipitate hydrolysis run using feeds containing both formate and aromatic carbons. ${ }^{18}$ The breakdown of the total carbon fed was $76 \%$ formate, $19 \%$ aromatic and $4 \%$ carbonate. On a mass basis, nearly $85 \%$ of the total aromatic carbon species fed was phenylboric acid (PBA), followed by phenol at close to $15 \%$, while biphenyl and terphenyl together accounted for less than 1\%. The SCM-2 was run at three different vapor space temperatures, and the lowest vapor space temperature of $450^{\circ} \mathrm{C}$ was achieved when the vapor space heaters were turned off. Due to insufficient data, the true gas temperature in the SCM-2 vapor space could not be calculated by the mass and energy balance. Instead, it was estimated by assuming the same $\Delta \mathrm{T}$ of $246^{\circ} \mathrm{C}$ between the measured vapor space and true gas temperatures as the average of three $\Delta \mathrm{T}^{\prime} \mathrm{s}$ obtained during feeding in Ref. [10]. The true gas temperature thus estimated was $204^{\circ} \mathrm{C}$ and it is the off-gas data collected during this nolid-heat feeding operation that the cold cap model predictions were validated against.

The results of the 4-stage cold cap model are compared to the $2^{\text {nd }} \mathrm{SCM}-2$ precipitate hydrolysis run data in Table 4-2. Overall, the model predictions are shown to be in excellent agreement with data in both the glass redox ratio and the calcine gas composition except for the TOC. Noting that $80 \%$ of the predicted TOC was due to benzene, the assumed $5 \%$ conversion of benzene (from the decomposition of PBA) may have been too low. In order to increase the conversion of benzene and bring the predicted TOC closer to the data, more $\mathrm{O}_{2}$ should be made available. Although the diffusion of air from the vapor space into the cold cap was not allowed in the model, it could have been overridden in this case based on the fact that the SCM-2 camera air purge was blown in right above the cold cap, as shown in Figure 3-2b, so it may have been possible for some air to diffuse into the top layer of the cold cap and react with some of the benzene. Again, the results shown in Table 4-2 seem to support the proposition that despite its $29 \%$ lower melt pool aspect ratio and rectangular cavity the SCM-2 melt pool was still prototypic enough. 
SRNL-STI-2012-00121

Revision 0

Table 4-2._4-Stage Cold Cap Model Validation II: SCM-2 Precipitate Hydrolysis Run.

\begin{tabular}{|c|c|c|}
\hline & Data $^{18}$ & Model \\
\hline \multicolumn{3}{|c|}{ Calcine Gases (lb/1,000 lb glass) } \\
\hline $\mathrm{CO}_{2}$ & 116 & 109 \\
\hline $\mathrm{CO}$ & 18.5 & 17.6 \\
\hline $\mathrm{H}_{2}$ & 3.0 & 3.2 \\
\hline $\mathrm{H}_{2} \mathrm{O}$ & $\mathrm{n} / \mathrm{a}$ & 70.2 \\
\hline $\mathrm{N}_{2}$ & $\mathrm{n} / \mathrm{a}$ & 4.0 \\
\hline TOC & 3.3 & 8.0 \\
\hline \multicolumn{3}{|l|}{ Glass } \\
\hline $\mathrm{Fe}^{2+} / \mathrm{Fe}^{3+}$ (mole/mole) & $0.49-0.59$ & 0.49 \\
\hline
\end{tabular}

The third set of data used for the validation of the 4-stage cold cap model was taken during the 774-A melter run with the sludge-only feed prepared using the alternate acid addition strategy that made the feed less oxidizing. ${ }^{13}$ The $774-A$ research melter was a $1 / 80^{\text {th }}$ scale melter based on melt surface area, and its melt pool aspect ratio was 1.3 just below that of the SCM-2 but had the same cylindrical geometry as the DWPF melter. The typical cold cap coverage during the SGM and SCM-2 melter runs was $80-90 \%$, and the observed overall conversion of nitrate to $\mathrm{NO}_{\mathrm{x}}$ was in the range of 30-60\%. ${ }^{11,17,18}$ By comparison, the cold cap coverage during the 774-A melter run was only about $20 \%$, so the cold cap residue was in greater contact with air, which would have resulted in higher conversion of nitrate into $\mathrm{NO}_{\mathrm{x}}$ according to Reaction (5). This was indeed the case; the data showed nearly $100 \%$ conversion, ${ }^{13}$ which is consistent with the trend seen in earlier melter runs that the concentration of $\mathrm{NO}_{\mathrm{x}}$ increases with increasing exposure to air, even if the data included additional $\mathrm{NO}_{\mathrm{x}}$ formed in the vapor space.

Based on these observations, the cold cap model was run by selectively removing $\mathrm{N}_{2}$ from the list of potential gaseous products for Stage 1 and 2. The removal of $\mathrm{N}_{2}$ has the same effect as forcing nitrate to decompose into $\mathrm{NO}_{\mathrm{x}}$ (and $\mathrm{O}_{2}$ ), thereby effectively reducing the oxidizing potential of nitrate. As a result, some of the $\mathrm{CO}$ and $\mathrm{H}_{2}$ produced by Reactions (2) and (6) could remain unburned. The nitrogen oxides produced via Reaction (5) further equilibrated with other gaseous products present at the assumed Stage 1 temperature of $873 \mathrm{~K}$.

With no lid heat, the measured vapor space temperature was $660^{\circ} \mathrm{C}$, and the true gas temperature in the 774-A melter vapor space was estimated to be $300^{\circ} \mathrm{C} .{ }^{13}$ It is the data collected during this no-lid-heat period that are compared to the 4-stage cold cap model predictions, as shown in Table 4-3. It is noted that the predicted concentration of $\mathrm{H}_{2}$ was right at the upper limit of the measured values, which suggests that additional combustion of $\mathrm{H}_{2}$ was occurring in the 774-A melter vapor space at the estimated gas temperature of $300^{\circ} \mathrm{C}$. It was indeed shown earlier that the combustion rates of both $\mathrm{CO}$ and $\mathrm{H}_{2}$ are not negligible at the gas temperature of $300^{\circ} \mathrm{C}$. ${ }^{3}$ On the other hand, the predicted glass redox was in good agreement with the data, which indicates that forcing the nitrate to decompose to $\mathrm{NO}_{\mathrm{x}}$ not only made the calculated concentration of $\mathrm{H}_{2}$ fall within the range of measured data but partitioned just enough oxygen to glass for a good match of the redox ratio. Thus, it may be concluded that although the conditions under which the 774-A melter was run were not ideal for validating the cold cap model, comparison of the resulting model predictions with data showed that the impacts of those less-than-ideal conditions such as the excessively-low cold cap coverage and not-low-enough vapor space temperature were still well captured by the 4-stage cold cap model. 
SRNL-STI-2012-00121

Revision 0

Table 4-3. 4-Stage Cold Cap Model Validation III: 774-A Melter Run.

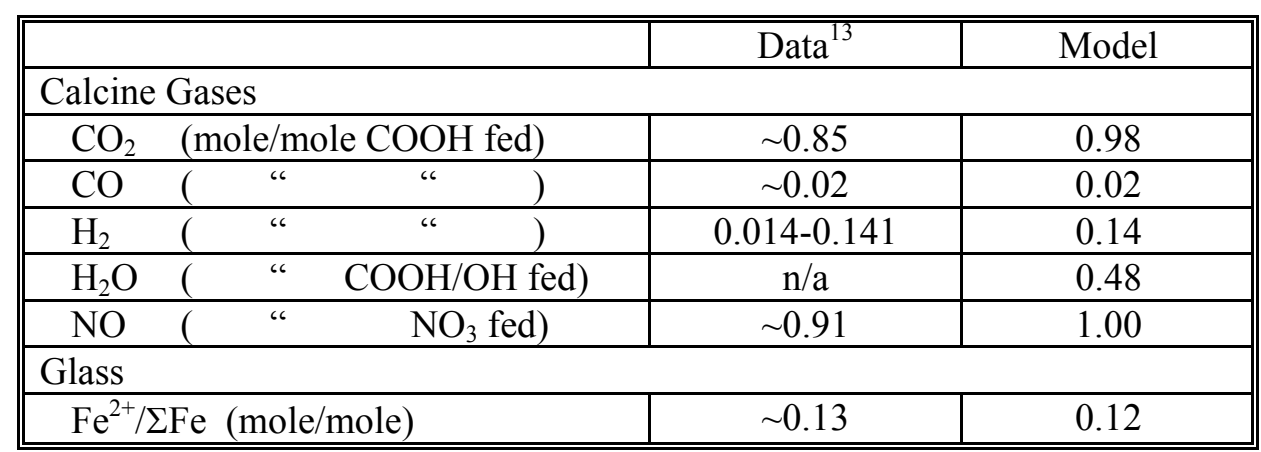

\subsection{Vapor Space Combustion Model}

The flammable components of the calcine gases along with the volatile feed components that boil off upon entering the melter react further in the vapor space before exiting the melter. The global kinetics approach is used to predict the overall combustion efficiency in the DWPF melter vapor space, and some of the key features of the model are highlighted in this section.

\subsubsection{Bases and Assumptions}

A first-order global kinetics model of $\mathrm{CO}$ and $\mathrm{H}_{2}$ oxidation was developed from the data taken during the $9^{\text {th }}$ Scale Glass Melter run (SGM-9) using the formic acid flowsheet feed spiked with high-boiling aromatic compounds: ${ }^{3,7}$

$$
-r=k_{o} \exp \left(-E_{a} / R T\right) C
$$

where $-r$ is the reaction rate in $1 \mathrm{bmole} / \mathrm{ft}^{3} / \mathrm{sec}, k_{o}$ the pre-exponential factor in $1 / \mathrm{sec}, E_{a}$ the activation energy in Btu/lbmole, $R$ the gas constant, $T$ the gas temperature in $\mathrm{K}$, and $C$ the concentration of $\mathrm{CO}$ or $\mathrm{H}_{2}$ in lbmole/ $\mathrm{ft}^{3}$. Assuming that the DWPF melter vapor space is wellmixed, the resulting global kinetic parameters empirically fitted to the SGM-9 data are given in Table $4-4 .^{3}$

Table 4-4. First-Order Global Kinetic Parameters for Vapor Space Oxidation.

\begin{tabular}{||c|c|c|c||}
\hline \hline & $\begin{array}{c}k_{o} \\
(1 / \mathrm{sec})\end{array}$ & $\begin{array}{c}E_{a} \\
(\text { Btu/lbmole })\end{array}$ & $\mathrm{R}^{2}$ \\
\hline $\mathrm{CO}$ & 1,759 & 22,192 & 0.845 \\
\hline $\mathrm{H}_{2}$ & $2.795 \mathrm{E} 7$ & 38,940 & 0.999 \\
\hline
\end{tabular}

As stated above, the intrinsic kinetics of oxidation, fluid mixing and heat transfer effects in the vapor space are all lumped into these global kinetic parameters. Since both fluid mixing and heat transfer are not only highly coupled but strongly dependent upon the geometry of the vapor space, it is expected that the geometric factors listed in Table 3-1 such as the vapor space-to-melt pool cross-sectional area ratio play a significant role in the calculation of the combustion efficiency. For example, when the DWPF global kinetic parameters given in Table 4-4 were applied to the data from the DM1200 LAW Envelope A1 run (DM1200-A1) in support of the Waste Treatment Plant (WTP) LAW safety basis analysis, the predicted concentrations of $\mathrm{CO}$ and $\mathrm{H}_{2}$ at the Wet Electrostatic Precipitator (WESP) exit were found to be lower than the measured averages by more than 20 and 50\%, respectively, which indicated that the DWPF global kinetic parameters over predicted the combustion efficiencies of $\mathrm{CO}$ and $\mathrm{H}_{2}$ in the DM1200 vapor space. ${ }^{19}$ 
Reduced combustion efficiencies of $\mathrm{CO}$ and $\mathrm{H}_{2}$ during DM1200-A1 run may be attributed to the differences in melter internal design, which may have led to not as efficient fluid mixing in the DM1200 vapor space as in the DWPF melter. First, the vapor space-to-melt pool cross-sectional area ratio of the DM1200 is estimated to be 1.2, while that of the DWPF melter is 1.0 at the melt surface and increases to 1.1 in the middle section of the vapor space. Therefore, steam and calcine gases exiting the cold cap should expand slightly more going into the DM1200 vapor space, resulting in reduced turbulence and thus lower fluid mixing efficiency than in the DWPF melter. Furthermore, the DM1200 cavity is rectangular, while that of the DWPF melter is cylindrical, and the overall mixing efficiency of the former geometry is known to be somewhat lower than that of the latter. This less efficient fluid mixing can be accounted for in the global kinetics model by increasing the activation energy, while leaving the pre-exponential factor untouched. It turned out that when the activation energies of $\mathrm{H}_{2}$ and $\mathrm{CO}$ oxidation were increased by $5.6 \%$ and $9.7 \%$, respectively, over their respective DWPF values, the predicted concentration of $\mathrm{H}_{2}$ and $\mathrm{CO} / \mathrm{CO}_{2}$ molar ratio at the WESP exit were found to be in good agreement with the DM1200-A1 data.

\subsubsection{Validation of Global Kinetics Model}

The global kinetic parameters shown in Table 4-4 were validated against the data taken during the SCM-2 and 774-A melter runs both fed with the formic acid flowsheet feeds. The off-gas data from the $2^{\text {nd }} \mathrm{SCM}-2$ precipitate hydrolysis run are given in Table $4-5 .{ }^{18}$ It is noted that the data taken at $450^{\circ} \mathrm{C}$ were already used for the validation of the 4-stage cold cap model in Table 4-2. The model-predicted composition of calcine gases shown in Table 4-2 was next used as the feed for the global combustion calculations at the measured vapor space temperatures of 637 and $833^{\circ} \mathrm{C}$ or the true gas temperatures of 391 and $587^{\circ} \mathrm{C}$, respectively, based on the $\Delta \mathrm{T}$ of $246^{\circ} \mathrm{C}$ between the measured vapor space and true gas temperatures during feeding. ${ }^{10}$ The average gas residence time in the SCM-2 vapor space was set at 4 seconds. ${ }^{18}$ As shown in Table 4-5, both CO and $\mathrm{H}_{2}$ were detected at the estimated gas temperature of $204^{\circ} \mathrm{C}$, whereas neither $\mathrm{CO}$ nor $\mathrm{H}_{2}$ was detected at the highest gas temperature of $587^{\circ} \mathrm{C}$. At the intermediate gas temperature of $391^{\circ} \mathrm{C}$, only $\mathrm{CO}$ was detected. Both quantitative and qualitative assessments are made next to see how closely the model was able to predict the data.

Table 4-5. Off-Gas Data from $2^{\text {nd }}$ SCM-2 Precipitate Hydrolysis Run.

\begin{tabular}{||c|c|c|c|c|c||}
\hline $\begin{array}{c}\text { Measured } \\
\text { Vapor Space } \\
\text { Temperature } \\
\left({ }^{\circ} \mathrm{C}\right)\end{array}$ & $\begin{array}{c}\text { Estimated } \\
\text { True Gas } \\
\text { Temperature } \\
\left({ }^{\circ} \mathrm{C}\right)\end{array}$ & $\begin{array}{c}\mathrm{H}_{2} \\
(\mathrm{lb} / 1,000 \mathrm{lb} \\
\text { Glass })\end{array}$ & $\begin{array}{c}\mathrm{CO} \\
(\mathrm{lb} / 1,000 \mathrm{lb} \\
\text { Glass })\end{array}$ & $\begin{array}{c}\mathrm{CO}_{2} \\
(\mathrm{lb} / 1,000 \mathrm{lb} \\
\text { Glass })\end{array}$ & $\begin{array}{c}\mathrm{TOC} \\
(\mathrm{lb} / 1,000 \mathrm{lb} \\
\text { Glass })\end{array}$ \\
\hline 833 & 587 & 0.0 & 0.0 & 201 & 0.1 \\
\hline 637 & 391 & 0.0 & 9.4 & 143 & 0.1 \\
\hline 450 & 204 & 3.0 & 18.5 & 116 & 3.3 \\
\hline
\end{tabular}

The calculated concentration profiles of $\mathrm{CO}$ and $\mathrm{H}_{2}$ using the first-order global kinetic parameters given in Table 4-4 are shown in Figure 4-2 as a function of gas temperature. Since the calculated composition of calcine gases shown in Table 4-2 was used as the input for the global combustion model, both $\mathrm{CO}$ and $\mathrm{H}_{2}$ concentration profiles are shown to asymptotically reach their respective input values at $204^{\circ} \mathrm{C}$. It is also shown that at $400^{\circ} \mathrm{C}$ the calculated concentration of CO equals the measured data at $391^{\circ} \mathrm{C}$ or the model over predicted the data by about $10^{\circ} \mathrm{C}$. This is equivalent to saying that at $391{ }^{\circ} \mathrm{C}$ the calculated concentration of $\mathrm{CO}$ was $7 \%$ higher than the measured value. The model also predicted that the concentration of $\mathrm{H}_{2}$ would become zero at gas temperatures above $380^{\circ} \mathrm{C}$, which agrees with the measured $\mathrm{H}_{2}$ concentration of zero at $391^{\circ} \mathrm{C}$. At $587^{\circ} \mathrm{C}$, the model predicted that neither $\mathrm{H}_{2}$ nor $\mathrm{CO}$ would prevail, which again agrees well with the data. 
SRNL-STI-2012-00121

Revision 0

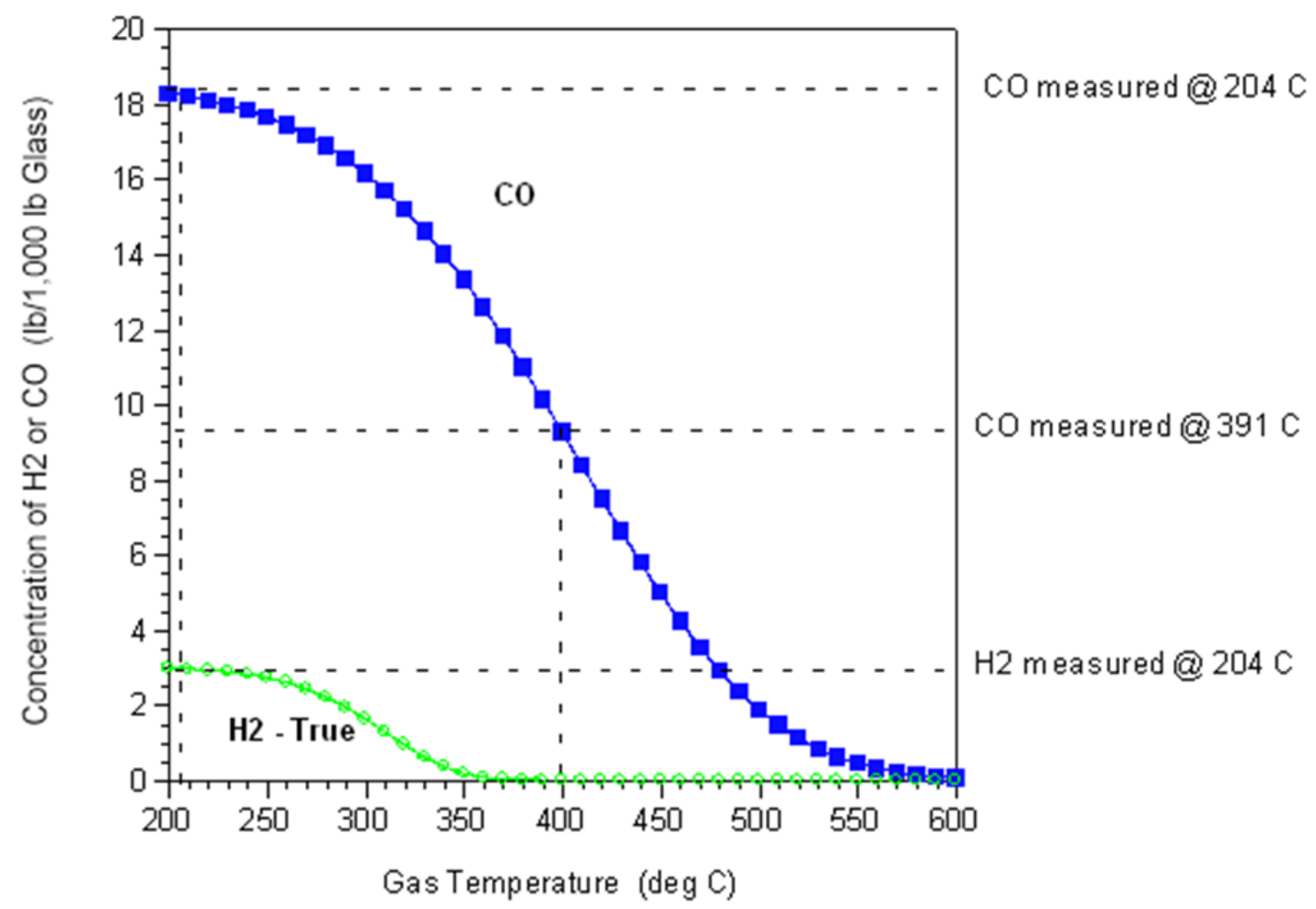

Figure 4-2. Calculated Concentration Profiles of $\mathrm{CO}$ and $\mathrm{H}_{2}$ vs. SCM-2 Data.

The SCM-2 had a $2 \mathrm{X}$ higher vapor space-to-melt pool cross-sectional area ratio than the DWPF melter. However, as noted earlier, the length of the SCM-2 melt pool was the same as that of its vapor space, so the $2 \mathrm{X}$ expansion of steam and calcine gases was side-to-side according to Figure $3-2 b$. Thus, it seems reasonable to assume that the overall mixing efficiency of gases in the SCM2 vapor space was somewhat higher than in those melters with the same cross-sectional area ratio but gases having to expand in all four directions, as in the 774-A, DM10, and DM100 melters. The relatively small difference between the calculated and measured $\mathrm{CO}$ concentrations at $391^{\circ} \mathrm{C}$ discussed above may be attributed to these geometric differences or even to the fact that the $\Delta \mathrm{T}$ of $246^{\circ} \mathrm{C}$ was applied unilaterally to all three measured temperatures, although $\Delta \mathrm{T}$ should decrease with decreasing vapor space temperature due to the diminishing effects of radiation. Therefore, it may be concluded that despite its non-prototypic cavity design the SCM-2 vapor space was still prototypic of the DWPF melter from the off-gas combustion standpoint.

The second set of data used to validate the global combustion model was obtained during the same 774-A melter run whose data were used earlier to validate the 4-stage cold cap model. ${ }^{13}$ Along with the contribution from the decomposition of free formic acid, the composition of the calcine gases calculated by the 4-stage cold cap model was used as the input for the global combustion model. In doing so, it was assumed that free formic acid would decompose in the vapor space to form $\mathrm{CO}$ and $\mathrm{H}_{2} \mathrm{O}$ by the dehydration route shown by Reaction (11): ${ }^{20,21}$

Dehydration: $\quad \mathrm{HCOOH} \rightarrow \mathrm{CO}+\mathrm{H}_{2} \mathrm{O}$

The average gas residence time in the 774-A melter vapor space was estimated to be 2.4 seconds during the less-oxidizing feed run. The calculated and measured concentrations of $\mathrm{H}_{2}$ and $\mathrm{CO}$ are compared in Figure 4-3 and Figure 4-4, respectively, as a function of estimated gas temperature. 


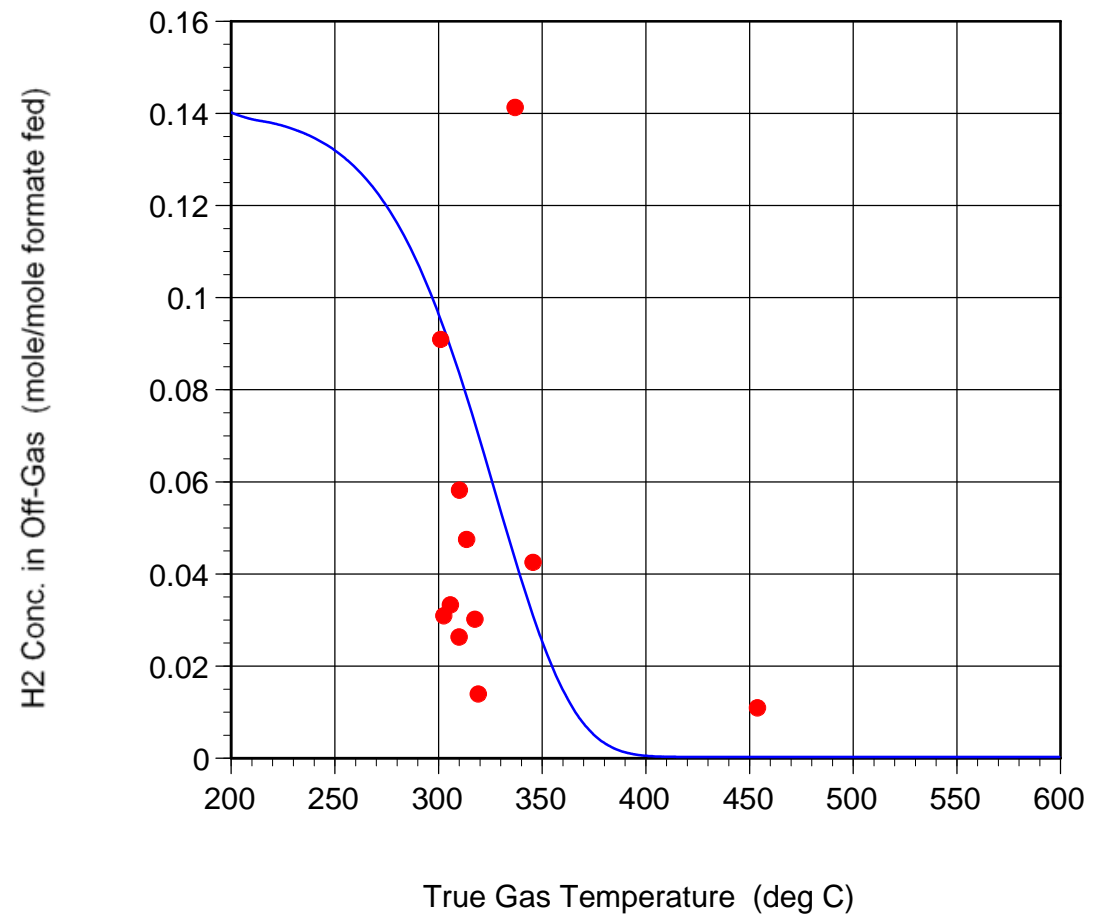

Figure 4-3. Calculated vs. Measured $\mathrm{H}_{2}$ Concentrations during 774-A Melter Run.

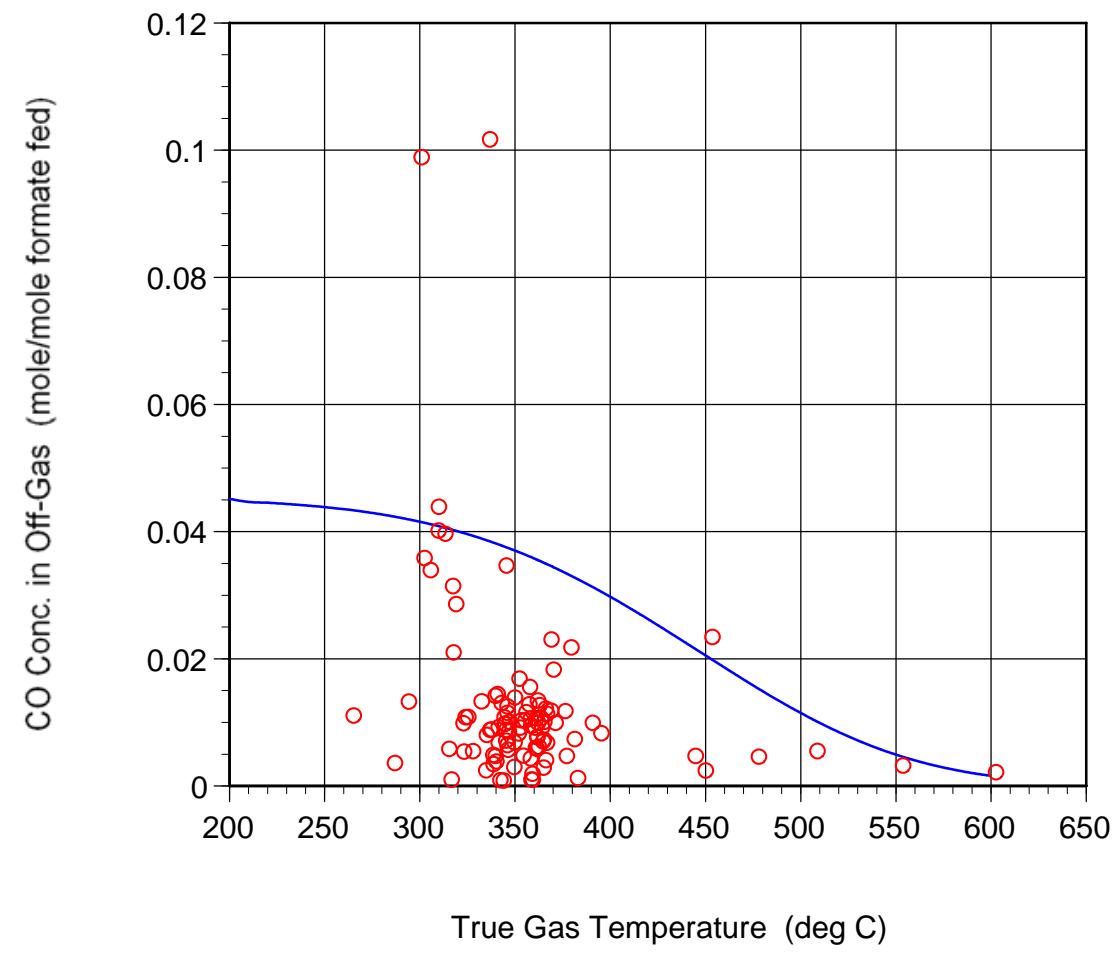

Figure 4-4. Calculated vs. Measured CO Concentrations during 774-A Melter Run. 
Several operational difficulties were encountered during the 774-A melter run such as difficulties in operating the gas chromatograph and the fact that both the feed rate and the vapor space temperature could not be maintained at their respective steady state values for any prolonged period of time mainly due to frequent pouring difficulties. These experimental difficulties are clearly reflected in the large scattering of data. The measured concentrations of $\mathrm{CO}$ and $\mathrm{CO}_{2}$ did not quite add up to the formate fed in terms of carbon balance, either. Despite these difficulties and the enormous complexity of the physical events taking place in the melter vapor space, the global combustion model is shown to bound the majority of data well except for a few outliers. The model predicts that the oxidation of $\mathrm{H}_{2}$ and $\mathrm{CO}$ would go to completion at gas temperatures above 380 and $600^{\circ} \mathrm{C}$, respectively, which is indeed consistent with the SCM-2 data shown in Table 4-5. These results suggest that the vapor space-to-melt pool cross-sectional area ratio of 2.9 for the 774-A melter which is almost $3 \mathrm{X}$ higher than that of the DWPF melter did not affect the outcome of the global combustion model.

However, ignoring the large scattering of data, the fact that the model bounded both $\mathrm{CO}$ and $\mathrm{H}_{2}$ data means that the model in general over predicted their concentrations, which in turn means that the overall combustion efficiency in the 774-A melter vapor space was at least equal to or even higher than that in the DWPF melter vapor space. This is exactly the opposite of what would be expected from the fact that the vapor space-to-melt pool cross-sectional area ratio of the 774-A melter was 2.6 times that of the DWPF melter and thus the overall mixing efficiency in the former was supposed to be inferior to that in the latter. As will be shown later in the CFD analysis, this seemingly-contradictory result arose from the fact that the 774-A melter vapor space was actively purged with air through a port in the lid and with its shorter vapor space height (or higher vapor space aspect ratio) the resulting air jet impinged on the cold cap with a greater momentum than it would in taller melters, thereby increasing the overall turbulence throughout its expanded vapor space.

\subsection{Application of DWPF Models}

The impact of melter internal design on the flammability potential of the melter off-gas was tested further against the data taken using non-DWPF feeds. To do so, the existing 4-stage cold cap and global off-gas combustion models were run to simulate the conditions under which each data set was taken and the applicability of the DWPF models to those non-DWPF feed melter run data was assessed in light of the differences in feed chemistry and melter internal design. Since the existing DWPF models were developed and calibrated using the formic-acid flowsheet feeds, an extensive search was conducted for the off-gas data produced from formated feeds. Only three such data sets were found and analyzed in this study. In order to expand the range of melter internal design parameters such as the cross-sectional area ratio and the melt pool aspect ratio, three additional data sets were also simulated despite the fact that they were obtained using feeds that included sugar as the only reductant. Thus, the total number of feed cases considered was six.

\subsection{PSCM-23}

The first data set was collected during the Pilot Scale Ceramic Melter Run 23 (PSCM-23). ${ }^{22}$ Except for having a rectangular cavity, the internal design of the PSCM was prototypic of the DWPF melter since its vapor space-to-melt pool cross-sectional area ratio and melt pool aspect ratio were 1.0 and 2.6, respectively, which are close to the corresponding DWPF values of 1.1 and 2.1, as shown in Table 3-1. In addition, the PSCM was a fairly large melter, $\sim 1 / 3^{\text {rd }}$ scale of DWPF melter based on melt surface area and, as in the SGM-9 run, was not bubbled. Unlike the DWPF or SGM, however, the PSCM vapor space was not actively air purged. 


\subsubsection{Input Data for PSCM-23Model Run}

The PSCM-23 run proceeded in four stages lasting 15 days total by varying the air flow to the film cooler and the flush water flow to the High Efficiency Mist Eliminator (HEME). The quenched off-gas downstream of the Submerged Bed Scrubber (SBS) was sampled on two different days with and without the film cooler air flow and analyzed for the combustible and non-combustible species including $\mathrm{H}_{2}, \mathrm{CO}, \mathrm{CH}_{4}, \mathrm{CO}_{2}, \mathrm{NO}_{\mathrm{x}}$, etc. Unfortunately, however, the overall carbon balance for the run without the film cooler air flow was so poor that only the data taken with the film cooler air flow were used. Some of the key operating conditions of the PSCM23 run are summarized in Table 5-1.

Table 5-1. PSCM-23 Operating Data for DWPF Model Runs.

\begin{tabular}{||l|r||}
\hline \hline Feed Rate $(\mathrm{L} / \mathrm{hr})$ & 44 \\
\hline Measured PSCM Vapor Space Temperature $\left({ }^{\circ} \mathrm{C}\right)$ & 518 \\
\hline PSCM Vapor Space Vacuum (in. $\left.\mathrm{H}_{2} \mathrm{O}\right)$ & 3.9 \\
\hline Film Cooler Air Flow (scfm) & 40 \\
\hline Off-Gas Temperature at SBS Inlet $\left({ }^{\circ} \mathrm{C}\right)$ & 186 \\
\hline SBS Inlet Vacuum (in. $\left.\mathrm{H}_{2} \mathrm{O}\right)$ & 6 \\
\hline Off-Gas Flow at SBS Outlet $(\mathrm{cfm})$ & 110 \\
\hline Off-Gas Temperature at SBS Outlet $\left({ }^{\circ} \mathrm{C}\right)$ & 35 \\
\hline SBS Outlet Vacuum (in. $\left.\mathrm{H}_{2} \mathrm{O}\right)$ & 40 \\
\hline
\end{tabular}

The simulated feed used was based on the FY 1987 Hanford Waste Vitrification Plant (HWVP) specification for the pretreated neutralized current acid waste (NCAW). Unlike the DWPF feeds, the PSCM-23 feed was high in $\mathrm{Zr}$ and La but was neutralized with enough formic acid to have leftover free formic acid. The feed was further augmented with sugar for a target glass redox of $<$ 0.3 , and the final melter feed composition is given in Table 5-2. The calculated partitioning of TOC among formate, oxalate, sugar and free formic was $23: 19: 31: 27$, respectively.

In setting up the input vector for the cold cap model run, the sugar was pre-decomposed as:

$$
\mathrm{C}_{12} \mathrm{H}_{22} \mathrm{O}_{11} \rightarrow 12 \mathrm{C}+11 \mathrm{H}_{2} \mathrm{O}
$$

The products of Reaction (12) were fed to Stages 1 and 2 of the cold cap model at the 50:50 ratios. It is noted that similar decomposition schemes that maximize the production of flammable gases was applied earlier to other nonvolatile organics fed during the SCM-9 run. ${ }^{12}$

\subsubsection{Results of DWPF Model Runs for PSCM-23}

The PSCM-23 feed composition given in Table 5-2 was fed to the current 4-stage cold cap model, and the resulting calcine gas composition calculated by the cold cap model was then fed to the global combustion model. Some of the key model results are compared to the data in Table 5-3. The true gas temperature in the PSCM vapor space was estimated to be $265^{\circ} \mathrm{C}$, which is not quite low enough to assume no combustion in the vapor space. Therefore, the results shown reflect the composite effects of both the cold cap and vapor space combustion reactions, and the calculated concentrations of $\mathrm{H}_{2}$ and $\mathrm{CO}$ in the quenched off-gas are shown to be in good agreement with their measured counterparts. 
Table 5-2. PSCM-23 Feed Composition.

\begin{tabular}{|c|c|c|c|}
\hline Insoluble Solids & $\mathrm{g} / \mathrm{L}$ slurry & Soluble Solids & $\mathrm{g} / \mathrm{L}$ slurry \\
\hline $\mathrm{Fe}(\mathrm{OH})_{3}$ & 49.31 & $\mathrm{CaHPO}_{4} \cdot \mathrm{H}_{2} \mathrm{O}$ & 1.21 \\
\hline $\mathrm{Al}(\mathrm{OH})_{3}$ & 18.11 & $\mathrm{Cr}\left(\mathrm{NO}_{3}\right)_{3} .9 \mathrm{H}_{2} \mathrm{O}$ & 2.06 \\
\hline $\mathrm{Ni}(\mathrm{OH})_{2}$ & 3.76 & $\mathrm{CsNO}_{3}$ & 1.09 \\
\hline $\mathrm{SiO}_{2}$ & 267.76 & $\mathrm{Mg}\left(\mathrm{NO}_{3}\right)_{2} \cdot 6 \mathrm{H}_{2} \mathrm{O}$ & 0.30 \\
\hline $\mathrm{Na}_{2} \mathrm{O}$ & 33.75 & $\mathrm{Mn}\left(\mathrm{NO}_{3}\right)_{2} \cdot 4 \mathrm{H}_{2} \mathrm{O}$ & 2.27 \\
\hline $\mathrm{B}_{2} \mathrm{O}_{3}$ & 52.50 & $\mathrm{NaCl}$ & 0.63 \\
\hline $\mathrm{Li} 2 \mathrm{O}$ & 18.75 & $\mathrm{NaF}$ & 0.79 \\
\hline $\mathrm{Ce}(\mathrm{OH})_{4}$ & 0.87 & $\mathrm{NaCOOH}$ & 17.79 \\
\hline $\mathrm{BaSO}_{4}$ & 0.80 & $\mathrm{NaNO}_{3}$ & 19.58 \\
\hline $\mathrm{MoO}_{3}$ & 1.58 & $\mathrm{NaNO}_{2}$ & 0.00 \\
\hline NdF3 & 2.02 & $\mathrm{Na}_{2} \mathrm{Cr}_{2} \mathrm{O}_{7} \cdot 2 \mathrm{H}_{2} \mathrm{O}$ & 0.53 \\
\hline $\operatorname{Pr}(\mathrm{OH})_{3}$ & 0.59 & $\mathrm{Na}_{2} \mathrm{HPO}_{4} \cdot 7 \mathrm{H}_{2} \mathrm{O}$ & 0.10 \\
\hline $\mathrm{LaF}_{3}$ & 1.97 & $\mathrm{Sr}\left(\mathrm{NO}_{3}\right)_{2}$ & 1.07 \\
\hline $\mathrm{Zr}(\mathrm{OH})_{4}$ & 25.51 & $\mathrm{La}\left(\mathrm{NO}_{3}\right)_{3} \cdot 6 \mathrm{H}_{2} \mathrm{O}$ & 17.25 \\
\hline $\mathrm{CuSO}_{4} .5 \mathrm{H}_{2} \mathrm{O}$ & 2.47 & $\mathrm{Na}_{2} \mathrm{C}_{2} \mathrm{O}_{4}$ & 13.95 \\
\hline $\mathrm{MgSO}_{4}$ & 1.23 & $\mathrm{Na}_{2} \mathrm{SO}_{4}$ & 0.65 \\
\hline $\mathrm{Sm}(\mathrm{OH})_{3}$ & 0.30 & Total Soluble & 79.27 \\
\hline $\mathrm{Y}(\mathrm{OH})_{3}$ & 0.33 & $\mathrm{HCOOH}(100 \%)$ & 13.88 \\
\hline $\mathrm{ZnO}$ & 2.50 & $\mathrm{H}_{2} \mathrm{O}$ & 733.46 \\
\hline $\mathrm{H}_{3} \mathrm{BO}_{3}$ & 0.23 & Total Slurry & 1328.45 \\
\hline $\mathrm{CaO}$ & 3.75 & Total Solids $(\mathrm{g} / \mathrm{L})$ & 594.99 \\
\hline $\mathrm{MgO}$ & 3.75 & Formate $(\mathrm{ppm})$ & 19,084 \\
\hline Sugar & 10.00 & Nitrate $(\mathrm{ppm})$ & 18,783 \\
\hline Total Insoluble & 501.84 & TOC (ppm) & 10,144 \\
\hline
\end{tabular}

On the other hand, the agreement between the measured and calculated glass redox $\left(\mathrm{Fe}^{2+} / \mathrm{Fe}^{3+}\right)$ does not appear to be as good at the first glance. However, the calculated redox was expected to be higher than the measured data, since the glass was air-lifted out of the PSCM melt pool using 2 scfm of air into a pour chamber, where additional contact with air could have occurred. It is not known how much lowering of the redox the air lift and subsequent contact with air would have caused; nevertheless, the calculated redox is in qualitative agreement with the data. Although not directly relevant, the impact of air contact on glass redox was measured recently; ${ }^{23}$ the measured redox $\left(\mathrm{Fe}^{2+} / \Sigma \mathrm{Fe}\right)$ of the alternate reductant flowsheet feed with a sugar ratio of 0.95 was 0.373 in a closed crucible, while the same feed resulted in a completely oxidized glass in an open crucible.

Table 5-3. Results of DWPF Model Runs to Simulate PSCM-23 Run.

\begin{tabular}{||l|c|c||}
\hline \hline & Data & Model \\
\hline Gas Residence Time in PSCM-23 Vapor Space (sec) & - & 7 \\
\hline Air Inleakage/Purge into PSCM Vapor Space (scfm) & - & 49.4 \\
\hline Actual PSCM Vapor Space Gas Temperature $\left({ }^{\circ} \mathrm{C}\right)$ & - & 265 \\
\hline $\mathrm{H}_{2}$ concentration in quenched off-gas (vol\%) & 0.01 & 0.008 \\
\hline $\mathrm{CO}$ concentration in quenched off-gas (vol\%) & $<0.1$ & 0.02 \\
\hline $\mathrm{Fe}^{2+} / \mathrm{Fe}^{3+}$ (mole/mole) & 0.055 & 0.205 \\
\hline
\end{tabular}


The pedigree of the PSCM-23 data was good in that the overall carbon balance was closed within $\pm 8 \%$. Therefore, it is concluded that the 4-stage cold cap and global combustion models together predicted the PSCM-23 data well, which seems to support the postulation that the melter internal design impacts the modes of fluid mixing and heat transfer, and such design parameters as the vapor space-to-melt pool cross-sectional area ratio need to be matched closely to ensure that comparable overall combustion efficiencies are achieved in differently scaled melters. The fact that all the major design and operating conditions of the PSCM-23 were similar to those of the SGM, including neither melt pool being agitated using bubblers and comparable gas residence times, gives additional credence to the validation results in Table 5-3, since it is the SGM-9 data that form the bases of the DWPF models.

\section{$5.2 \quad$ RSM Runs}

The second and third data sets came from a series of the Research Scale Melter (RSM) runs in $2003 .^{24}$ Despite its small size, $\sim 1 / 140^{\text {th }}$ DWPF scale based on melt surface area, the internal design of the RSM was more prototypic of the DWPF melter than the PSCM was; its melt pool aspect ratio and vapor space-to-melt pool cross-sectional area ratio were 2.0 and 1.0, respectively, compared to 2.1 and 1.1 for the DWPF melter, and it also had a cylindrical cavity. The difference between the two RSM runs selected was in the amounts of $\mathrm{Hg}, \mathrm{Cl}$ and sugar added to the baseline feed. The first RSM feed was produced by doping the baseline feed with low $\mathrm{Hg}$ but high $\mathrm{Cl}$ and sugar (termed RSM-LHH), while the second RSM feed was doped also with high $\mathrm{Cl}$ and sugar but contained the maximum level of $\mathrm{Hg}$ (termed RSM-MHH). The baseline feed for both RSM runs was Hanford Tank C-104/AY-101 HLW simulant, and $\mathrm{Hg}$ and $\mathrm{Cl}$ were added as $\mathrm{Hg}\left(\mathrm{NO}_{3}\right)_{2} \cdot \mathrm{H}_{2} \mathrm{O}$ and $\mathrm{NaCl}$, respectively. The $\mathrm{RSM}$ was bubbled with air at a rate of $0.09 \mathrm{scfm} / \mathrm{ft}^{2}$ melt surface, which is equivalent to $52 \%$ of the baseline argon bubbling rate for the DWPF melter.

\subsubsection{RSM-LHH Run}

The total duration of the RSM-LHH run was only 7.6 hours. Since it was the $3^{\text {rd }}$ of the seven consecutive melter runs made each time using different feeds, there was a good likelihood of not having enough melter turnovers to have the impact of feed chemistry properly reflected on the glass composition including the glass redox. However, the impact of not having enough melter turnovers on the off-gas composition should be minimal since it takes typically less than one hour to burn off the cold cap in a much larger melter. For example, during the DM10-A2 run, ${ }^{25}$ it took less than 19 minutes to burn off much of the excess cold cap that had accumulated during the 40 minutes of heavy overfeeding. And the design and operating conditions that affect the cold cap burn-off rate were similar during the RSM and DM10 runs; both melters have the same apparent melt surface area of $0.2 \mathrm{ft}^{2}$ and the lid heaters were either absent (RSM) or not used (DM10).

\subsubsection{Input Data for RSM-LHH Model Run}

Some of the key operating conditions of the RSM-LHH test are summarized in Table 5-4. The melter turnover rate at the nominal feed rate of $1.5 \mathrm{~L} / \mathrm{hr}$ was given as 4.5 hours. ${ }^{24}$ Therefore, at the given feed rate of $0.94 \mathrm{~L} / \mathrm{hr}$, the actual melter turnover rate is estimated to be 7.2 hours, which means that the maximum melter turnover ratio during the RSM-LHH run was one. As suspected, therefore, the RSM-LHH glass never had enough time to fully reflect its feed chemistry. Furthermore, at the target $90-95 \%$ cold cap coverage and with no lid heat, the measured RSM vapor space temperature was $395^{\circ} \mathrm{C}$. 
Table 5-4. RSM-LHH Operating Data for DWPF Model Runs.

\begin{tabular}{||l|c||}
\hline Feed Rate (L/hr) & 0.94 \\
\hline Measured RSM Vapor Space Temperature $\left({ }^{\circ} \mathrm{C}\right)$ & 395 \\
\hline RSM Vapor Space Vacuum (in. $\left.\mathrm{H}_{2} \mathrm{O}\right)$ & 3.3 \\
\hline Film Cooler Air Flow (scfm) & 2.3 \\
\hline Off-Gas Temperature at Quencher Inlet $\left({ }^{\circ} \mathrm{C}\right)$ & 242 \\
\hline Quencher Inlet Vacuum (in. $\left.\mathrm{H}_{2} \mathrm{O}\right)$ & $\mathrm{n} / \mathrm{a}$ \\
\hline Off-Gas Flow at Quencher Inlet $($ acfm) & 10.9 \\
\hline
\end{tabular}

The composition of the RSM-LHH feed is given in Table 5-5; it was high in $\mathrm{Zr}$ as in the PSCM23 feed. Unlike the DWPF feeds, its Zn content was also high and its $\mathrm{pH}$ was alkaline. One characteristic feature of the RSM-LHH feed was that its nitrate and TOC levels were both very low at 633 and 1,594 ppm, respectively.

Table 5-5. RSM-LHH Feed Composition.

\begin{tabular}{|c|c|c|c|}
\hline Insoluble Solids & g/L slurry & Soluble Solids & g/L slurry \\
\hline $\mathrm{Fe}(\mathrm{OH})_{3}$ & 65.44 & $\mathrm{CsOH}$ & 0.27 \\
\hline $\mathrm{Al}(\mathrm{OH})_{3}$ & 29.72 & $\mathrm{Li}_{2} \mathrm{CO}_{3}$ & 43.29 \\
\hline $\mathrm{MnO}_{2}$ & 9.68 & $\mathrm{Na}_{2} \mathrm{~B}_{4} \mathrm{O}_{7}$ & 80.53 \\
\hline $\mathrm{Ca}(\mathrm{OH})_{2}$ & 3.35 & $\mathrm{NaCl}$ & 0.55 \\
\hline $\mathrm{Ni}(\mathrm{OH})_{2}$ & 3.09 & $\mathrm{NaF}$ & 1.37 \\
\hline $\mathrm{Cr}_{2} \mathrm{O}_{3}$ & 0.33 & $\mathrm{NaI}$ & 0.61 \\
\hline $\mathrm{CuO}$ & 0.15 & $\mathrm{NaNO}_{3}$ & 3.49 \\
\hline $\mathrm{TiO}_{2}$ & 0.11 & $\mathrm{NaNO}_{2}$ & 0.84 \\
\hline $\mathrm{SiO}_{2}$ & 241.24 & $\mathrm{NaOH}$ & 6.51 \\
\hline $\mathrm{ZnO}$ & 11.23 & $\mathrm{Na}_{2} \mathrm{CO}_{3}$ & 45.73 \\
\hline $\mathrm{La}(\mathrm{OH})_{3} .3 \mathrm{H}_{2} \mathrm{O}$ & 1.24 & $\mathrm{Na}_{2} \mathrm{C}_{2} \mathrm{O}_{4}$ & 1.16 \\
\hline $\mathrm{Zr}(\mathrm{OH})_{4} \cdot \mathrm{XH}_{2} \mathrm{O}$ & 62.75 & Total Soluble & 184.36 \\
\hline $\mathrm{H}_{3} \mathrm{BO}_{3}$ & 0.96 & $\mathrm{H}_{2} \mathrm{O}$ & 829.95 \\
\hline $\mathrm{FePO}_{4} \cdot \mathrm{XH}_{2} \mathrm{O}$ & 0.44 & Total Slurry & $1,450.69$ \\
\hline $\mathrm{PbO}$ & 0.64 & & \\
\hline $\mathrm{Nd}_{2} \mathrm{O}_{3}$ & 0.56 & Total Solids $(\mathrm{g} / \mathrm{L})$ & 620.74 \\
\hline $\mathrm{Hg}\left(\mathrm{NO}_{3}\right)_{2} \cdot \mathrm{H}_{2} \mathrm{O}$ & 0.44 & Formate $(\mathrm{ppm})$ & 0 \\
\hline Sugar & 5.00 & Nitrate/Nitrite (ppm) & 2,252 \\
\hline Total Insoluble & 436.38 & TOC (ppm) & 1,594 \\
\hline
\end{tabular}

\subsubsection{Results of DWPF Model Runs for RSM-LHH}

The RSM-LHH feed composition given in Table 5-5 was fed to the 4-stage cold cap model, and the resulting calcine gas composition was then fed to the global combustion model. Some of the key model results are compared to the data in Table 5-6. The true gas temperature in the RSM vapor space was estimated to be $371{ }^{\circ} \mathrm{C}$, which is clearly too high to assume no combustion in the vapor space. Therefore, the results shown reflect the composite effects of both the cold cap and vapor space combustion reactions. It is clearly shown that the DWPF models over predicted the measured concentrations of $\mathrm{H}_{2}$ and $\mathrm{CO}$ in the unquenched RSM off-gas, as shown under the column heading "Model" in Table 5-6. This indicates that the overall combustion efficiency may 
have been actually higher in the RSM than in the DWPF melter despite the fact that the calculated gas residence time during the RSM-LHH run was only 1.1 second compared to the nominal gas residence time of 7 seconds for the DWPF. Or it may suggest that the models are not applicable at such short gas residence times. As stated earlier, the DWPF models were derived from the data taken during the SGM-9 run, where the nominal gas residence time was 7 seconds. So, additional model runs were made next to see the impact of gas residence time on the combustion efficiency.

Table 5-6. Results of DWPF Model Runs to Simulate RSM-LHH Run.

\begin{tabular}{||l|c|c|c|c||}
\hline \hline & Data & Model & Model-3s & Model-7s \\
\hline Gas Residence Time in Vapor Space $(\mathrm{sec})$ & - & 1.1 & 3 & 7 \\
\hline Air Inleakage/Purge into Vapor Space $(\mathrm{scfm})$ & - & 3.2 & 3.2 & 3.2 \\
\hline Actual Vapor Space Gas Temperature $\left({ }^{\circ} \mathrm{C}\right)$ & - & 371 & 371 & 371 \\
\hline $\mathrm{H}_{2}$ concentration @ Q Quencher Inlet $(\mathrm{vol} \%)$ & $<0.001$ & 0.006 & 0.0005 & 0.000 \\
\hline $\mathrm{CO}$ concentration @ Quencher Inlet $(\mathrm{vol} \%)$ & 0.001 & 0.006 & 0.005 & 0.003 \\
\hline $\mathrm{Fe}^{2+} / \mathrm{SFe}$ (mole/mole) & 0.06 & 0.12 & 0.12 & 0.12 \\
\hline \hline
\end{tabular}

When the gas residence time was arbitrarily increased from 1.1 to 3 seconds (therefore, called Model-3s) at the same gas temperature and fuel concentrations, the calculated concentration of $\mathrm{H}_{2}$ is shown to drop by an order of magnitude to be in line with the data, while the reduction in $\mathrm{CO}$ concentration was less pronounced. When the gas residence time was further increased to 7 seconds (therefore, called Model-7s), the calculated concentration of $\mathrm{H}_{2}$ is shown to decrease essentially to zero, while the concentration of $\mathrm{CO}$ was reduced to $50 \%$ of its value at 1 second gas residence time. In fact, these results were expected from the global kinetics model construct, Eq. (10); the overall combustion efficiency is determined not only by the gas temperature $(T)$ and fuel concentrations $(C)$ but by the gas residence time which depends on both the vapor space volume (design variable) and the bulk gas flow rate (operating variable) as well as the gas temperature (both design and operating variables). The transport effects such as fluid mixing and heat transfer are accounted for by the activation energy $\left(E_{a}\right)$ which in turn depends on not only the intrinsic kinetics but the design of melter internals. Therefore, it may be concluded that the existing DWPF models failed to predict the RSM-LHH data, since its gas residence time was outside the range of the SGM data on which these models are based.

Table 5-6 also shows that the DWPF cold cap model over predicted the RSM-LHH glass redox in terms of iron valence ratio $\left(\mathrm{Fe}^{2+} / \Sigma \mathrm{Fe}\right)$. In fact, the calculated redox was expected to be higher than the measured data since the RSM melt pool was bubbled with air and there were not enough melter turnovers to flush out the glass produced with the low-sugar feeds during the preceding runs. Thus, the calculated glass redox was at least in qualitative agreement with the data.

\subsubsection{RSM-MHH Run}

The RSM-MHH run lasted only 6.8 hours. Since it was the last of the seven consecutive melter runs made and the three preceding runs used low-sugar feeds, there was a good likelihood of not having enough melter turnovers to have the impact of feed chemistry properly reflected on the glass composition, including the glass redox. However, the impact of not having enough melter turnovers on the off-gas composition should be minimal, since it takes much less than 6.8 hours to burn off the cold cap, as discussed above. Furthermore, the RSM vapor space was not actively purged with air in either run. 


\subsubsection{Input Data for RSM-MHH Model Run}

Some of the key operating conditions of the RSM-MHH test are summarized in Table 5-7. Based on the given melter turnover rate of 4.5 hours at the nominal feed rate of $1.5 \mathrm{~L} / \mathrm{hr}$, the actual melter turnover rate during the RSM-MHH run is estimated to be 6.1 hours, which means that there was barely one melter turnover during the RSM-MHH run. Therefore, the RSM-MHH glass would never have had enough time to fully reflect its feed chemistry. At the target $90-95 \%$ cold cap coverage with no lid heat, the measured RSM vapor space temperature was $402^{\circ} \mathrm{C}$.

Table 5-7. RSM-MHH Operating Data for DWPF Model Runs.

\begin{tabular}{||l|r||}
\hline \hline Feed Rate (L/hr) & 1.1 \\
\hline Measured RSM Vapor Space Temperature $\left({ }^{\circ} \mathrm{C}\right)$ & 402 \\
\hline RSM Vapor Space Vacuum (in. $\left.\mathrm{H}_{2} \mathrm{O}\right)$ & 3.5 \\
\hline Film Cooler Air Flow (scfm) & 3.0 \\
\hline Off-Gas Temperature at Quencher Inlet $\left({ }^{\circ} \mathrm{C}\right)$ & 190.5 \\
\hline Quencher Inlet Vacuum (in. $\left.\mathrm{H}_{2} \mathrm{O}\right)$ & $\mathrm{n} / \mathrm{a}$ \\
\hline Off-Gas Flow at Quencher Inlet $(\mathrm{acfm})$ & 9.68 \\
\hline
\end{tabular}

The composition of the RSM-MHH feed is given in Table 5-8. Since the baseline HLW simulant was the same in both RSM feeds, the overall characteristics of its feed chemistry including the $\mathrm{pH}$ remained the same as those of the RSM-LHH feed. One exception was that its nitrate level was 4X higher since a maximum amount of $\mathrm{Hg}$ was added as $\mathrm{Hg}\left(\mathrm{NO}_{3}\right)_{2} \cdot \mathrm{H}_{2} \mathrm{O}$. However, these nitrate and TOC levels are still lower than those of the DWP feeds almost by an order of magnitude.

Table 5-8. RSM-MHH Feed Composition.

\begin{tabular}{|c|c|c|c|}
\hline Insoluble Solids & g/L slurry & "Soluble Solids & g/L slurry \\
\hline $\mathrm{Fe}(\mathrm{OH})_{3}$ & 64.63 & $\mathrm{CsOH}$ & 0.27 \\
\hline $\mathrm{Al}(\mathrm{OH})_{3}$ & 29.35 & $\mathrm{Li}_{2} \mathrm{CO}_{3}$ & 43.29 \\
\hline $\mathrm{MnO}_{2}$ & 9.57 & $\mathrm{Na}_{2} \mathrm{~B}_{4} \mathrm{O}_{7}$ & 80.53 \\
\hline $\mathrm{Ca}(\mathrm{OH})_{2}$ & 3.31 & $\mathrm{NaCl}$ & 0.54 \\
\hline $\mathrm{Ni}(\mathrm{OH})_{2}$ & 3.06 & $\mathrm{NaF}$ & 1.37 \\
\hline $\mathrm{Cr}_{2} \mathrm{O}_{3}$ & 0.33 & $\mathrm{NaI}$ & 0.61 \\
\hline $\mathrm{CuO}$ & 0.15 & $\mathrm{NaNO}_{3}$ & 3.49 \\
\hline $\mathrm{TiO}_{2}$ & 0.11 & $\mathrm{NaNO}_{2}$ & 0.84 \\
\hline $\mathrm{SiO}_{2}$ & 238.27 & $\mathrm{NaOH}$ & 6.51 \\
\hline $\mathrm{ZnO}$ & 11.10 & $\mathrm{Na}_{2} \mathrm{CO}_{3}$ & 45.73 \\
\hline $\mathrm{La}(\mathrm{OH})_{3} \cdot 3 \mathrm{H}_{2} \mathrm{O}$ & 1.23 & $\mathrm{Na}_{2} \mathrm{C}_{2} \mathrm{O}_{4}$ & 1.16 \\
\hline $\mathrm{Zr}(\mathrm{OH})_{4} \cdot \mathrm{xH}_{2} \mathrm{O}$ & 61.98 & Total Soluble & 184.35 \\
\hline $\mathrm{H}_{3} \mathrm{BO}_{3}$ & 0.95 & $\mathrm{H}_{2} \mathrm{O}$ & 829.95 \\
\hline $\mathrm{FePO}_{4} \cdot \mathrm{xH}_{2} \mathrm{O}$ & 0.44 & Total Slurry & $1,453.15$ \\
\hline $\mathrm{PbO}$ & 0.63 & & \\
\hline $\mathrm{Nd}_{2} \mathrm{O}_{3}$ & 0.55 & Total Solids $(\mathrm{g} / \mathrm{L})$ & 623.20 \\
\hline $\mathrm{Hg}\left(\mathrm{NO}_{3}\right)_{2} \cdot \mathrm{H}_{2} \mathrm{O}$ & 8.26 & Formate (ppm) & 0 \\
\hline Sugar & 4.94 & Nitrate/Nitrite $(\mathrm{ppm})$ & 4,197 \\
\hline Total Insoluble & 438.85 & TOC (ppm) & 1,574 \\
\hline
\end{tabular}




\subsubsection{Results of DWPF Model Runs for RSM-MHH}

Some of the key results of the DWPF model runs simulating the RSM-MHH run are compared to the measured data in Table 5-9. The true gas temperature in the RSM vapor space was estimated to be $347^{\circ} \mathrm{C}$, which is clearly too high to assume no combustion in the vapor space. Therefore, the results shown again reflect the composite effects of both the cold cap and vapor space combustion reactions. As expected, the calculated concentrations of $\mathrm{H}_{2}$ and $\mathrm{CO}$ in the unquenched off-gas are both lower than those calculated with the RSM-LHH feed, since its nitrate level was 4X higher at nearly identical TOC levels. Unlike the RSM-LHH case, however, the model is shown to predict the $\mathrm{H}_{2}$ data well within its range at the calculated gas residence time of 1.4 second, which is only a fraction of a second longer than that of the RSM-LHH. The model under predicted the CO data. However, since all the concentrations shown in Table 5-9 are so low, i.e., in the 1-6 ppm $\mathrm{v}_{\mathrm{v}}$ range due to markedly low levels of TOC that the measured and calculated concentrations of both CO and $\mathrm{H}_{2}$ may be regarded as essentially identical.

Table 5-9. Results of DWPF Model Runs to Simulate RSM-MHH Run.

\begin{tabular}{||l|c|c||}
\hline & Data & Model \\
\hline Gas Residence Time in Vapor Space $(\mathrm{sec})$ & - & 1.4 \\
\hline Air Inleakage/Purge into Vapor Space $(\mathrm{scfm})$ & - & 2.3 \\
\hline Actual Vapor Space Gas Temperature $\left({ }^{\circ} \mathrm{C}\right)$ & - & 347 \\
\hline $\mathrm{H}_{2}$ Concentration @ Quencher Inlet $(\mathrm{vol} \%)$ & $<0.001$ & 0.0002 \\
\hline $\mathrm{CO}$ Concentration @ Quencher Inlet (vol\%) & 0.0006 & 0.0001 \\
\hline $\mathrm{Fe}^{2+} / \mathrm{Fe}$ (mole/mole) & 0.02 & 0.12 \\
\hline
\end{tabular}

As expected, the 4-stage cold cap model again over predicted the redox $\left(\mathrm{Fe}^{2+} / \Sigma \mathrm{Fe}\right)$ of the RSMMHH glass, since the melt pool was bubbled with air. However, the degree of over prediction was somewhat greater than that of the RSM-LHH glass due to lower measured redox of the RSMMHH glass, which was attributed to the fact that the RSM-MHH glass was exposed to ambient air for an extended period of time due to pouring difficulties. ${ }^{24}$ Therefore, it can be concluded that the RSM-MHH data, including the glass redox at least qualitatively, did not contradict the DWPF model predictions, which in turn seems to support the postulation that the melter internal design parameters such as the vapor space-to-melt pool cross-sectional area ratio are the key design variables for achieving comparable overall combustion efficiencies in differently scaled melters. It appears that this conclusion is valid not only for the formic-acid flowsheet feeds but for feeds containing sugar as the reductant, since the decomposition scheme for sugar shown by Reaction (12) seemed to work for predicting both the off-gas and glass redox data from the PSCM-23 and RSM runs.

\subsection{DM10 Runs}

The fourth and fifth data sets came from the DM10 runs in 2002 and 2011, respectively. ${ }^{25,26}$ Like the RSM, the DM10 is a $1 / 140^{\text {th }}$ scale melter based on melt surface area, and its melt pool aspect ratio and vapor space-to-melt pool cross-sectional area ratio are 0.8 and 5.8, respectively, compared to 2.1 and 1.1 for the DWPF melter. As noted earlier, the melt pool aspect ratio of the DM10 is the lowest of all the melters shown in Table 3-1, while its vapor space-to-melt pool cross-sectional area ratio is the highest. 


\subsubsection{DM10-A2 Run}

The fourth data set analyzed in this study came during the DM10 test in 2002 using Hanford's LAW sub-Envelope A2 simulant with sugar as the reductant, called DM10-A2. ${ }^{25}$ The DM10-A2 run lasted 4.5 hours and consisted of two alternating feeding and idling cycles in succession. The DM10 was first overfed for 40 minutes in an attempt to achieve the lowest possible vapor space temperature, and then the feed was stopped to burn off the excess cold cap for 15 minutes. The second cycle consisted of a short 5-minute feeding and a long idling for the remainder of the duration. It was noted that the measured off-gas flow downstream of the film cooler remained relatively constant with an average flow rate of $24.8 \mathrm{scfm}$ during the first idling period, and it was the data taken during this idling period that were simulated by the DWPF models.

\subsubsection{Input Data for DM10-A2 Model Run}

Some of the key operating conditions of the DM10-A2 run are summarized in Table 5-10. With no lid heat at $100 \%$ cold cap coverage, the measured vapor space temperature averaged only $191^{\circ} \mathrm{C}$ during the first idling period. Since the film cooler air was turned off, the measured off-gas temperature downstream of the film cooler should equal the gas temperature in the vapor space assuming no heat loss between the melter and the sampling point. However, the measured off-gas temperature downstream of the film cooler was $197^{\circ} \mathrm{C}$, which is $6^{\circ} \mathrm{C}$ higher than the measured vapor space temperature. Since the measured vapor space temperature cannot be lower than the actual gas temperature due to the radiation effect, this small $\Delta \mathrm{T}$ of $6^{\circ} \mathrm{C}$ indicates that the radiation effect was insignificant at the measured vapor space temperature of $191{ }^{\circ} \mathrm{C}$, which was expected, and thus the two temperatures were essentially the same.

It is also noted that the given feed rate of $8.5 \mathrm{~L} / \mathrm{hr}$ is higher than those of the RSM runs almost by an order of magnitude despite the fact that both melters have nearly identical melt surface areas. In fact, the given feed rate was not measured but rather back-calculated based on the measured average off-gas flow rate of $24.8 \mathrm{scfm}$ assuming a steady state operation. It turns out that the calculated total carbon feed rate at the $8.5 \mathrm{~L} / \mathrm{hr}$ slurry feed rate matches the sum of the average flow rates of carbon as $\mathrm{CO}$ and $\mathrm{CO}_{2}$ in the off-gas within $6 \%$. The excellent carbon balance indicates that the assumed steady state feed rate of $8.5 \mathrm{~L} / \mathrm{hr}$ correctly reflect the measured off-gas flow and its composition both averaged over the 14-15 minutes of idling right after the first feeding cycle was terminated.

Table 5-10. DM10-A2 Operating Data for DWPF Model Runs.

\begin{tabular}{||l|r||}
\hline \hline Feed Rate $(\mathrm{L} / \mathrm{hr})$ & 8.5 \\
\hline Measured DM10 Vapor Space Temperature $\left({ }^{\circ} \mathrm{C}\right)$ & 191 \\
\hline DM10 Vapor Space Vacuum (in. $\left.\mathrm{H}_{2} \mathrm{O}\right)$ & 3.5 \\
\hline Film Cooler Air Flow (scfm) & 0 \\
\hline Off-Gas Temperature downstream of Film Cooler $\left({ }^{\circ} \mathrm{C}\right)$ & 197 \\
\hline Off-Gas Flow downstream of Film Cooler $(\mathrm{scfm})$ & 24.8 \\
\hline
\end{tabular}

The composition of the DM10-A2 feed including the glass forming chemicals is given in Table 5-11. Unlike the HLW simulants used in the PSCM-23 and RSM runs, the DM10-A2 feed was characterized by high nitrate, while over $90 \%$ of the more modest level of TOC was due to sugar. Therefore, the feed was very oxidizing, and the flammability potential of the resulting off-gas was expected to be low. 
Table 5-11. DM10-A2 Feed Compositon.

\begin{tabular}{|c|c|c|c|}
\hline Insoluble Solids & $\mathrm{g} / \mathrm{L}$ slurry & Soluble Solids & $\mathrm{g} / \mathrm{L}$ slurry \\
\hline $\mathrm{Al}\left(\mathrm{NO}_{3}\right)_{3} .9 \mathrm{H}_{2} \mathrm{O}$ & 88.20 & $\mathrm{CsNO}_{3}$ & 1.86 \\
\hline $\mathrm{TiO}_{2}$ & 19.21 & $\mathrm{KOH}$ & 45.58 \\
\hline $\mathrm{SiO}_{2}$ & 327.33 & $\mathrm{NaCl}$ & 6.43 \\
\hline $\mathrm{ZnO}$ & 26.79 & $\mathrm{NaF}$ & 7.13 \\
\hline $\mathrm{H}_{3} \mathrm{BO}_{3}$ & 159.06 & $\mathrm{NaCOOH}$ & 2.25 \\
\hline Sugar & 55.77 & $\mathrm{NaNO}_{3}$ & 106.89 \\
\hline $\mathrm{Al}_{2} \mathrm{SiO}_{5}$ & 66.65 & $\mathrm{NaNO}_{2}$ & 58.40 \\
\hline $\mathrm{CaSiO}_{3}$ & 39.85 & $\mathrm{NaOH}$ & 112.65 \\
\hline $\mathrm{Fe}_{2} \mathrm{O}_{3}$ & 48.12 & $\mathrm{Na}_{2} \mathrm{CrO}_{4} \cdot 4 \mathrm{H}_{2} \mathrm{O}$ & 0.61 \\
\hline $\mathrm{Mg}_{2} \mathrm{SiO}_{4}$ & 27.64 & $\mathrm{Na}_{3} \mathrm{PO}_{4} \cdot 12 \mathrm{H}_{2} \mathrm{O}$ & 3.81 \\
\hline $\mathrm{ZrSiO}_{4}$ & 40.71 & $\mathrm{Na}_{2} \mathrm{C}_{2} \mathrm{O}_{4}$ & 3.41 \\
\hline \multirow[t]{2}{*}{ Total Insoluble } & 899.34 & $\mathrm{Na}_{2} \mathrm{SO}_{4}$ & 6.55 \\
\hline & & $\mathrm{CH}_{3} \mathrm{COONa}$ & 4.69 \\
\hline Total Solids $(\mathrm{g} / \mathrm{L})$ & $1,260.79$ & KI & 1.19 \\
\hline Formate $(\mathrm{ppm})$ & 858 & Total Soluble & 361.45 \\
\hline Nitrate/Nitrite (ppm) & 92,762 & $\mathrm{H}_{2} \mathrm{O}$ & 477.48 \\
\hline TOC (ppm) & 14,886 & Total Slurry & $1,738.27$ \\
\hline
\end{tabular}

\subsubsection{Results of DWPF Model Runs for DM10-A2}

Some of the key results of the DWPF model runs simulating the DM10-A2 run are given in Table 5-12 along with the measured data. It is clearly shown that the DWPF models under predicted the measured concentrations of $\mathrm{H}_{2}$ and $\mathrm{CO}$. As shown earlier in Figure 4-2, the true gas temperature of $197^{\circ} \mathrm{C}$ in the DM10 vapor space is actually low enough to assume no combustion in the vapor space, which means that the under prediction of $\mathrm{H}_{2}$ and $\mathrm{CO}$ concentrations must be due to the differences in the way the feed is converted into calcine gases and glass in the DM10 cold cap compared to the SGM or DWPF cold cap. In other words, it appears that the overall efficiency of the DM10 cold cap in terms of oxidizing the flammable gases produced from the cold cap and melt reactions is lower than that of the SGM or DWPF cold cap.

Table 5-12. Results of DWPF Model Runs to Simulate DM10-A2 Run.

\begin{tabular}{||l|c|c||}
\hline & Data & Model \\
\hline Gas Residence Time in Vapor Space $(\mathrm{sec})$ & - & 1 \\
\hline Air Inleakage into Vapor Space $(\mathrm{scfm})$ & - & 20 \\
\hline Actual Vapor Space Gas Temperature $\left({ }^{\circ} \mathrm{C}\right)$ & - & 197 \\
\hline $\mathrm{H}_{2}$ Concentration downstream of Film Cooler $(\mathrm{vol} \%)$ & 0.017 & 0.000 \\
\hline $\mathrm{CO}$ Concentration downstream of Film Cooler $\left(\mathrm{vol}^{2}\right)$ & 0.012 & 0.000 \\
\hline $\mathrm{Fe}^{2+} / \mathrm{Fe}($ mole/mole) & - & 0.18 \\
\hline
\end{tabular}

In fact, the net oxidizing potential of the DM10-A2 feed was so high at $\sim 89,000 \mathrm{ppm}$ nitrate and a more modest 15,000 ppm TOC that being a thermodynamic equilibrium based model, the 4-stage cold cap model was expected to reflect this large imbalance between the oxidant and reductant by predicting no flammable gas generation. However, the predicted redox of 0.18 was unusually high, and this was due to the fact that unlike the DWPF feed the DM10-A2 feed completely 
lacked $\mathrm{Li}$, which forced most $\mathrm{Al}$ to combine with $\mathrm{Fe}$ to form $\mathrm{FeAl}_{2} \mathrm{O}_{4}(l)$ in the melt phase, where the letter $l$ denotes liquid and $\mathrm{Fe}$ is in the +2 oxidation state. When the model was adjusted by moving $\mathrm{FeAl}_{2} \mathrm{O}_{4}(l)$ from the melt phase to the spinel phase, the predicted redox decreased to 0.01 , which is more in line with the expected value of zero; however, the predicted $\mathrm{H}_{2}$ and $\mathrm{CO}$ concentrations remained zero. It means that a significant degree of gas bypassing was likely to have occurred in the DM10 cold cap; otherwise, any flammable gases produced would have been oxidized in the presence of excess nitrate. Although the relative depth of the DM10 melt pool with respect to its equivalent diameter was more than $2 \mathrm{X}$ that of the DWPF melter, the impact of the melt pool aspect ratio on the DM10-A2 data is expected to be small, since the DM10 melt pool was bubbled with air at less than $5 \%$ of the DWPF rate.

It is known that the tendency for the cold cap bridging increases with decreasing melt surface area. Being a $1 / 140^{\text {th }}$ scale melter, the tendency for the DM10 cold cap to bridge was likely to be high especially with minimal bubbling. Furthermore, since it was also severely overfed during the DM10-A2 run, it seems plausible to assume that gas bypassing occurred within its thick cold cap, thus producing unburned flammable gases even in the presence of excess nitrate. Therefore, it is not conclusive at this point whether the under prediction of the $\mathrm{H}_{2}$ and $\mathrm{CO}$ data by the DWPF cold cap model was due to the non-prototypic design of the DM10 (melt pool aspect ratio and/or scale factor) or the abnormal operating mode employed during the DM10-A2 run.

\subsubsection{DM10-SB6 Run}

The fifth data set analyzed in this study came during the DM10 test in 2011 using the DWPF SB6 simulant adjusted with formic acid, called DM10-SB6. ${ }^{26}$ It was also the second of the three data sets based on formated feeds. The DM10-SB6 data were actually analyzed earlier to support the down-select and reanalyzed here with an emphasis on the impact of melter design on the data. ${ }^{27}$ Efforts were again made to achieve as low a vapor space temperature as practically possible, as was done during the DM10-A2 run. However, instead of overfeeding, the DM10 vapor space was cooled this time by introducing ambient air directly into the vapor space, while maintaining a constant feed rate; therefore, it was presumed to be non-disruptive to the steady state operation.

\subsubsection{Input Data for DM10-SB6 Model Run}

Some of the key operating conditions of the DM10-SB6 test are summarized in Table 5-13. With the vapor space heaters turned off and the ambient air coming in, the measured vapor space temperature averaged $296^{\circ} \mathrm{C}$ at $1.1 \mathrm{~L} / \mathrm{hr}$ feed rate. It is noted that this steady state feed rate is more in line with those of the RSM runs, which is an indication that the method of vapor space cooling using ambient air was indeed non-disruptive to the steady state operation. The film cooler air was heated to $257^{\circ} \mathrm{C}$, but the measured off-gas temperature at the film cooler exit was lower at $226^{\circ} \mathrm{C}$, which means that the gas temperature in the DM10 vapor space was considerably lower than that of the film cooler air.

Table 5-13. DM10-SB6 Operating Data for DWPF Model Runs.

\begin{tabular}{||l|r||}
\hline Feed Rate (L/hr) & 1.1 \\
\hline Measured DM10 Vapor Space Temperature $\left({ }^{\circ} \mathrm{C}\right)$ & 296 \\
\hline DM10 Vapor Space Vacuum (in. $\left.\mathrm{H}_{2} \mathrm{O}\right)$ & 1.0 \\
\hline Film Cooler Air Flow $(\mathrm{scfm})$ & 15 \\
\hline Film Cooler Air Temperature $\left({ }^{\circ} \mathrm{C}\right)$ & 257 \\
\hline Off-Gas Temperature @ Film Cooler Exit $\left({ }^{\circ} \mathrm{C}\right)$ & 226 \\
\hline Off-Gas Flow @ Transition Line Exit $(\mathrm{dscfm})$ & 27 \\
\hline
\end{tabular}


The composition of the DM10-SB6 feed including the glass-forming frit is given in Table 5-14. It had less than $1 / 5^{\text {th }}$ of the nitrate in the DM10-A2 feed, while its TOC was only $14 \%$ lower. Furthermore, the charge balance calculations showed that at the measured $\mathrm{pH}$ of 4.1 over $30 \%$ of the TOC was in the form of free formic acid, which volatilizes upon entering the melter without participating in the cold cap reactions. Thus, the net oxidizing potential of the DM10-SB6 feed was considerably lower than that of the DM10-A2 feed.

Table 5-14. DM10-SB6 Feed Composition.

\begin{tabular}{|c|c|c|c|}
\hline Insoluble Solids & g/L slurry & Soluble Solids & g/L slurry \\
\hline $\mathrm{Fe}(\mathrm{OH})_{3}$ & 61.11 & $\mathrm{Ca}\left(\mathrm{NO}_{3}\right)_{2}$ & 0.35 \\
\hline $\mathrm{Al}(\mathrm{OH})_{3}$ & 71.13 & $\mathrm{KNO}_{3}$ & 0.22 \\
\hline $\mathrm{MnO}_{2}$ & 8.18 & $\mathrm{Mg}\left(\mathrm{NO}_{3}\right)_{2}$ & 0.42 \\
\hline $\mathrm{Ca}(\mathrm{OH})_{2}$ & 0.21 & $\mathrm{Mn}(\mathrm{COOH})_{2}$ & 11.70 \\
\hline $\mathrm{Mg}(\mathrm{OH})_{2}$ & 1.48 & $\mathrm{NaCl}$ & 1.00 \\
\hline $\mathrm{Ni}(\mathrm{OH})_{2}$ & 5.84 & $\mathrm{NaF}$ & 0.10 \\
\hline $\mathrm{Cr}(\mathrm{OH})_{3}$ & 0.37 & $\mathrm{NaCOOH}$ & 51.57 \\
\hline $\mathrm{Cu}(\mathrm{OH})_{2}$ & 0.63 & $\mathrm{NaNO}_{3}$ & 25.92 \\
\hline $\mathrm{TiO}_{2}$ & 0.07 & $\mathrm{Ni}\left(\mathrm{NO}_{3}\right)_{2}$ & 1.28 \\
\hline $\mathrm{SiO}_{2}$ & 202.91 & $\mathrm{Na}_{2} \mathrm{SO}_{4}$ & 0.76 \\
\hline $\mathrm{Na}_{2} \mathrm{O}$ & 21.31 & Total Soluble & 93.31 \\
\hline $\mathrm{Zn}(\mathrm{OH})_{2}$ & 0.03 & $\mathrm{HCOOH}$ & 20.45 \\
\hline $\mathrm{Cd}(\mathrm{OH})_{2}$ & 0.05 & $\mathrm{H} 2 \mathrm{O}$ & 747.55 \\
\hline $\mathrm{B}_{2} \mathrm{O}_{3}$ & 21.31 & Total Slurry & $1,280.00$ \\
\hline $\mathrm{Li}_{2} \mathrm{O}$ & 21.31 & Total Solids $(\mathrm{g} / \mathrm{L})$ & 512.00 \\
\hline $\mathrm{ZrO}_{2}$ & 0.52 & Formate $(\mathrm{ppm})$ & 47,970 \\
\hline $\mathrm{CaSO}_{4}$ & 2.25 & Nitrate (ppm) & 16,034 \\
\hline Total Insoluble & 418.69 & TOC (ppm) & 12,784 \\
\hline
\end{tabular}

\subsubsection{Results of DWPF Model Runs for DM10-SB6}

Some of the key results of the DWPF model runs simulating the DM10-SB6 are shown in Table 5-15 along with measured data. The total air purge into the DM10 vapor space was estimated to be $12 \mathrm{scfm}$, of which more than $80 \%$ was the active air purge in the form of cooling air, while the remaining $20 \%$ or so was the air inleakage. At the measured vapor space temperature of $296^{\circ} \mathrm{C}$, the actual gas temperature was calculated to be $190^{\circ} \mathrm{C}$, which is low enough to assume no combustion in the DM10 vapor space. Thus, the results shown reflect the effects of the cold cap and melt reactions only under the design and operating conditions of the DM10. As expected from the feed chemistry, the DM10-SB6 calcine gases are predicted to contain some $\mathrm{H}_{2}$ and $\mathrm{CO}$ compared to zero $\mathrm{H}_{2}$ and $\mathrm{CO}$ predicted for the DM10-A2 feed. However, the 4-stage cold cap model still under predicted measured data, particularly the $\mathrm{H}_{2}$ by an order of magnitude, which indicates that some degree of gas bypassing is likely to have occurred during the DM10-SB6 run. Unlike the DM10-A2 run, however, the DM10 was not overfed, so gas bypassing in the cold cap cannot be attributed to abnormal operation, which seems to suggest that the under prediction may be related to the design of the DM10. In fact, gas bypassing cannot be eliminated completely, since the multistage reactor model depicted in Figure 4-1 is only an idealization of the actual cold cap that has a highly heterogeneous and dynamic domain with a not-easy-to-define physical boundary. Comparison of model predictions and the data from both DM10 runs seems to suggest that gas bypassing may have been more severe in the DM10 compared to the PSCM and RSM. 
SRNL-STI-2012-00121

Revision 0

Table 5-15. Results of DWPF Model Runs to Simulate DM10-SB6 Run.

\begin{tabular}{||l|c|c||}
\hline & Data & Model \\
\hline Gas Residence Time in Vapor Space $(\mathrm{sec})$ & - & 2 \\
\hline Air Inleakage/Purge into Vapor Space $(\mathrm{scfm})$ & - & 12 \\
\hline Actual Vapor Space Gas Temperature $\left({ }^{\circ} \mathrm{C}\right)$ & - & 190 \\
\hline $\mathrm{H}_{2}$ Concentration downstream of Film Cooler (vol\%) & 0.0110 & 0.0010 \\
\hline $\mathrm{CO}$ Concentration downstream of Film Cooler (vol\%) & 0.0025 & 0.0012 \\
\hline $\mathrm{Fe}^{2+} / \mathrm{Fe}$ (mole/mole) & $<0.01$ & 0.11 \\
\hline
\end{tabular}

\section{$5.4 \quad$ DM100-A2 Runs}

The sixth and final data set was obtained during the DM100 runs in 2002 with the Hanford's LAW sub-Envelope A2 simulant using formic acid as the reductant, called DM100-A2. ${ }^{28}$ The test was run in three segments using three different formic acid concentrations, and the data used in this study were taken during the $3^{\text {rd }}$ segment of the test that lasted for 1 hour. The DM100 is a $1 / 24^{\text {th }}$ scale melter based on melt surface area. Like the DM10, the internal design of the DM100 is also quite different from the DWPF melter; its melt pool aspect ratio and vapor space-to-melt pool cross-sectional area ratio are 0.8 and 3.3, respectively, compared to 2.1 and 1.1 for the DWPF melter.

\subsubsection{Input Data for DM100-A2 Model Run}

Some of the key operating conditions of the DM100-A2 test are summarized in Table 5-16; these data are used in the mass and energy balance calculations to estimate the melter air inleakage and the actual gas temperature in the vapor space. The measured vapor space temperature averaged $610^{\circ} \mathrm{C}$. The film cooler air was preheated to $300^{\circ} \mathrm{C}$, and the measured off-gas temperature at the film cooler exit was just $5^{\circ} \mathrm{C}$ lower at $295^{\circ} \mathrm{C}$. The melt pool was agitated using air bubblers at 21 $\mathrm{L} / \mathrm{min}$ or $0.12 \mathrm{scfm} / \mathrm{ft}^{2}$ melt surface, which is equivalent to $\sim 70 \%$ of the DWPF rate.

Table 5-16. DM100-A2 Operating Data for DWPF Model Runs.

\begin{tabular}{||l|r||}
\hline \hline Nitrate/TOC (mole/mole) & $1 / 1.5$ \\
\hline Air Bubbling Rate $\left(\mathrm{scfm} / \mathrm{ft}^{2}\right.$ melt surface) & 0.12 \\
\hline Measured DM100 Vapor Space Temperature $\left({ }^{\circ} \mathrm{C}\right)$ & 610 \\
\hline DM100 Vapor Space Vacuum (in. $\left.\mathrm{H}_{2} \mathrm{O}\right)$ & 4 \\
\hline Film Cooler Air Flow (dscfm) & 300 \\
\hline Film Cooler Air Temperature $\left({ }^{\circ} \mathrm{C}\right)$ & 295 \\
\hline Off-Gas Temperature @ Film Cooler Exit $\left({ }^{\circ} \mathrm{C}\right)$ & 34.6 \\
\hline Off-Gas Flow @ Transition Line Exit $(\mathrm{dscfm})$ & 6.1 \\
\hline Moisture Content @ Monitoring Point $(\mathrm{vol} \%)$ & 131 \\
\hline Off-Gas Flow @ Monitoring Point $(\mathrm{dscfm})$ & \\
\hline
\end{tabular}

The composition of the DM100-A2 feed including the glass-forming frit is given in Table 5-17; it was constructed from the sub-Envelope A2 simulant recipe by replacing sugar with formic acid at the target (nitrate + nitrite)-to-TOC molar ratio of $1 / 1.5 .^{29}$ In doing so, hydroxides were converted to formate, glycolate, and citrate by neutralization with their respective acids. It turns out that not enough acids were available to neutralize all hydroxides and have leftover free acids in the final feed. $93 \%$ of the TOC was due to formate carbon. 
Table 5-17. DM100-A2 Feed Composition.

\begin{tabular}{|c|c|c|c|}
\hline Insoluble Solids & g/L slurry & Soluble Solids & g/L slurry \\
\hline $\mathrm{Fe}(\mathrm{NO} 3)_{3} .9 \mathrm{H}_{2} \mathrm{O}$ & 0.02 & $\mathrm{Ca}\left(\mathrm{NO}_{3}\right)_{2} \cdot 4 \mathrm{H}_{2} \mathrm{O}$ & 0.20 \\
\hline $\mathrm{Al}\left(\mathrm{NO}_{3}\right)_{3} \cdot 9 \mathrm{H}_{2} \mathrm{O}$ & 119.07 & $\mathrm{CsNO}_{3}$ & 1.87 \\
\hline $\mathrm{NiO}$ & 0.07 & $\mathrm{KCOOH}$ & 39.38 \\
\hline $\mathrm{TiO}_{2}$ & 18.37 & $\mathrm{NaCl}$ & 1.91 \\
\hline $\mathrm{SiO}_{2}$ & 313.75 & $\mathrm{NaF}$ & 4.45 \\
\hline $\mathrm{ZnO}$ & 26.04 & $\mathrm{NaCOOH}$ & 219.66 \\
\hline $\mathrm{H}_{3} \mathrm{BO}_{3}$ & 155.32 & $\mathrm{NaNO}_{3}$ & 77.18 \\
\hline $\mathrm{Al}_{2} \mathrm{SiO}_{5}$ & 70.42 & $\mathrm{NaNO}_{2}$ & 54.15 \\
\hline $\mathrm{CaSiO}_{3}$ & 37.05 & $\mathrm{NaOH}$ & 9.33 \\
\hline $\mathrm{Fe}_{2} \mathrm{O}_{3}$ & 45.57 & $\mathrm{Na}_{2} \mathrm{CrO}_{4} \cdot 4 \mathrm{H}_{2} \mathrm{O}$ & 0.43 \\
\hline $\mathrm{Mg}_{2} \mathrm{SiO}_{4}$ & 27.32 & $\mathrm{Na}_{3} \mathrm{PO}_{4} \cdot 12 \mathrm{H}_{2} \mathrm{O}$ & 3.48 \\
\hline $\mathrm{ZrSiO}_{4}$ & 39.48 & $\mathrm{Na}_{2} \mathrm{CO}_{3}$ & 21.44 \\
\hline \multirow[t]{2}{*}{ Total Insoluble } & 852.48 & $\mathrm{Na}_{2} \mathrm{C}_{2} \mathrm{O}_{4}$ & 0.64 \\
\hline & & $\mathrm{Na}_{2} \mathrm{SO}_{4}$ & 5.56 \\
\hline \multirow[t]{2}{*}{ Total Solids } & $1,303.13$ & $\mathrm{CH}_{3} \mathrm{COONa}$ & 1.94 \\
\hline & & $\mathrm{Na}_{2}$ EDTA. $2 \mathrm{H}_{2} \mathrm{O}$ & 0.79 \\
\hline Formate (ppm) & 89,019 & $\mathrm{Na}_{2}$ HEDTA. $2 \mathrm{H}_{2} \mathrm{O}$ & 0.96 \\
\hline Nitrate/Nitrite (ppm) & 81,364 & $\mathrm{Na}$ Gluconate & 0.67 \\
\hline \multirow[t]{8}{*}{ TOC $(\mathrm{ppm})$} & 25,592 & Na Glycolate & 3.10 \\
\hline & & Na Citrate & 2.30 \\
\hline & & NTA $^{*}$ & 0.61 \\
\hline & & $\mathrm{IDA}^{* *}$ & 0.61 \\
\hline & & Total Soluble & 450.65 \\
\hline & & $\mathrm{HCOOH}$ & 0.00 \\
\hline & & $\mathrm{H}_{2} \mathrm{O}$ & 567.02 \\
\hline & & Total Slurry & $1,870.15$ \\
\hline
\end{tabular}

\subsubsection{Results of DWPF Model Run for DM100-A2}

Some of the key results of the DWPF model runs simulating the DM100-A2 test are shown in Table 5-18 along with measured data. Since the feed rate was not given in Reference 28, it was back-calculated by simultaneously matching the calculated moisture content of the off-gas at the monitoring point against the measured value of $6.1 \mathrm{vol} \%$ and the calculated off-gas flow at the Transition Line against the measured value of $34.6 \mathrm{dscfm}$. The slurry feed rate thus calculated was $12.7 \mathrm{~L} / \mathrm{hr}$. The air inleakage into the DM100 vapor space was then calculated to be $15.8 \mathrm{scfm}$. The true gas temperature in the DM100 vapor space was calculated to be $291^{\circ} \mathrm{C}$ at the measured temperature of $610^{\circ} \mathrm{C}$. This corresponds to the $\Delta \mathrm{T}$ of $319^{\circ} \mathrm{C}$, which seems high but actually is in line with the range of $\Delta \mathrm{T}$ 's given in Table 3-2 for the SCM-2, considering the fact that the DM100 vapor space-to-melt pool cross-sectional area ratio of 3.3 is higher than that of the SCM2 and that $\Delta \mathrm{T}$ increases with increasing cross-sectional area ratio.

The estimated gas temperature of $291{ }^{\circ} \mathrm{C}$ is clearly too high to assume no combustion in the vapor space. Therefore, the results shown reflect the composite effects of both the cold cap and vapor space reactions. It is shown that the DWPF models again under predicted the measured $\mathrm{H}_{2}$ and CO data, as they did for the DM10-A2 and DM10-SB6. This means that the overall performances of the DM10 and DM100 in terms of burning off flammable gases in the cold cap and the vapor 
space are markedly lower than those of the PSCM and RSM for the range of feed chemistry (HLW vs. LAW and sugar vs. formic acid) and operating conditions (high vs. low vapor space temperature, active vs. passive air purges, and bubbled vs. non-bubbled) considered in this study. The calculated iron redox ratio of glass is shown to be considerably higher than the measured value of near zero in part because the DM100 melt pool was agitated using air bubblers and also due to the artifact of the model that the DM100-A2 feed lacked Li, as discussed in Section 5.3.1.2.

Table 5-18. Results of DWPF Model Runs to Simulate DM100-A2 Run.

\begin{tabular}{||l|c|c||}
\hline & Data & Model \\
\hline Feed Rate (L/hr) & - & 12.5 \\
\hline Gas Residence Time in DM100 Vapor Space (sec) & - & 8.6 \\
\hline Air Inleakage into DM100 Vapor Space (scfm) & - & 15.7 \\
\hline Actual Vapor Space Gas Temperature ( $\left.{ }^{\circ} \mathrm{C}\right)$ & - & 291 \\
\hline $\begin{array}{l}\text { Air Inleakage between Transition Line and } \\
\text { Monitoring Point (scfm) }\end{array}$ & 96.4 & 97.6 \\
\hline $\mathrm{H}_{2}$ Concentration @ Monitoring Point (vol\%) & 0.028 & 0.000 \\
\hline $\mathrm{CO}$ Concentration @ Monitoring Point (vol\%) & 0.068 & 0.000 \\
\hline $\mathrm{CO}_{2}$ Concentration @ Monitoring Point (vol\%) & $<1.0$ & 0.54 \\
\hline $\mathrm{Fe}^{2+} / \Sigma \mathrm{Fe}$ (mole/mole) & $<0.01$ & 0.19 \\
\hline
\end{tabular}

Another design parameter that could impact the cold cap reactions is the vapor space-to-melt pool cross-sectional area ratio. At a given measured vapor space temperature, the cold cap sees more vapor space surfaces and thus receives more radiant heat as the vapor space-to-melt pool crosssectional area ratio increases. As a result, the cold cap residues in the melter with a higher crosssectional area ratio will melt and thus move down into the melt pool faster, leaving less time for the cold cap reactions to go to completion, including the oxidation of flammable gases. Therefore, the net result will be a lower overall efficiency of the cold cap reactions than in the melter with a lower cross-sectional area ratio. In other words, the 4-stage cold cap model always predicts the maximum efficiency dictated by the thermodynamic equilibrium, which in principle requires an infinite amount of reaction time, whereas under real situations only a finite amount of time is given for the cold cap reactions. As the cold cap residues are forced to flux faster into the melt, e.g., by convective stirring of the melt pool, the departure from the thermodynamic equilibrium becomes greater. So, the under prediction of both DM10 off-gas data by the 4-stage cold cap model may be explained by its high vapor space-to-melt pool cross-sectional area ratio.

\subsection{Summary of DWPF Model Simulation of Off-Site Melter Runs}

The results of the DWPF model simulation of non-DWPF feed off-site melter runs discussed so far are summarized in Table 5-19 along with some of the key design and operating parameters in comparison to those of the DWPF melter. Also shown are the SCM-2 and 774-A melter runs whose data were used to validate the DWPF models as described earlier. Going from left to right of Table 5-19, the melters are listed in the order of increasing vapor space-to-melt pool crosssectional area ratio, which represents the degree of expansion that the cold cap gases undergo as they enter the vapor space. Incidentally, the melt pool aspect ratios of these melters are shown to be in the reverse order, i.e., decreasing melt pool aspect ratio (or increasing melt pool depth relative to its diameter) with increasing vapor space-to-melt pool cross-sectional ratio. The exception was the PSCM, whose melt pool aspect ratio was the highest of all melters tested. Both the vapor space-to-melt pool cross-sectional area ratio and the melt pool aspect ratio constitute the melter cavity design parameters. 
Table 5-19. Summary of DWPF Model Predictions vs. Data.

\begin{tabular}{|c|c|c|c|c|c|c|c|c|c|}
\hline Run ID & DWPF & $\begin{array}{l}\text { RSM- } \\
\text { LHH }\end{array}$ & $\begin{array}{l}\text { RSM- } \\
\text { MHH }\end{array}$ & \begin{tabular}{|c|} 
PSCM- \\
23
\end{tabular} & SCM-2 & 774-A & $\begin{array}{c}\text { DM100- } \\
\text { A2 }\end{array}$ & $\begin{array}{l}\text { DM10- } \\
\text { A2 }\end{array}$ & $\begin{array}{l}\text { DM10- } \\
\text { SB6 }\end{array}$ \\
\hline \multicolumn{10}{|l|}{$\begin{array}{l}\text { Overall Geometry of } \\
\text { Melt Pool \& Vapor Space }\end{array}$} \\
\hline Melt Surface (x DWPF) & 1 & $1 / 140$ & $1 / 140$ & $1 / 3$ & $1 / 28$ & $1 / 80$ & $1 / 24$ & $1 / 140$ & $1 / 140$ \\
\hline $\begin{array}{l}\text { Vapor Space-to-Melt Pool } \\
\text { Cross-sectional Area Ratio }\end{array}$ & 1.1 & 1.0 & 1.0 & 1.0 & 2.2 & 2.9 & 3.3 & 5.8 & 5.8 \\
\hline Melt Pool Aspect Ratio & 2.1 & 2.0 & 2.0 & 2.6 & 1.5 & 1.3 & 0.8 & 0.8 & 0.8 \\
\hline Active Air Purge? & Yes & No & No & No & Yes & Yes & No & No & Yes $^{* *}$ \\
\hline Air Inleakage (scfm) & 22 & 3 & 2 & 49 & 12 & $\sim 0$ & 16 & 20 & 2 \\
\hline Melt Pool Bubbled? & Yes & Yes & Yes & No & No & No & Yes & No & No \\
\hline Gas Residence Time (sec) & 7 & 1.1 & 1.4 & 6.7 & 4 & 2.4 & 8.6 & 1.0 & 2.0 \\
\hline Reductant Used & Formic & Sugar & Sugar & $\begin{array}{l}\text { Formic/ } \\
\text { Sugar }\end{array}$ & Formic & Formic & Formic & Sugar & Formic \\
\hline Model Prediction of $\mathrm{H}_{2}$ & - & Over & $\mathrm{OK}$ & $\mathrm{OK}$ & $\mathrm{OK}$ & $\mathrm{OK}$ & Under & Under & Under \\
\hline Model Prediction of CO & - & Over & $\mathrm{OK}$ & $\mathrm{OK}$ & $\mathrm{OK}$ & $\mathrm{OK}$ & Under & Under & Under \\
\hline Models Checked & - & Both & Both & Both & Both $^{*}$ & Both $^{*}$ & Both & Cold Cap & Cold Cap \\
\hline
\end{tabular}


As stated above, the operating conditions under which these melters were run were diverse: bubbled vs. non-bubbled, formic acid vs. sugar reductant, high vs. low vapor space temperature, and active vs. passive air purges. It is shown that regardless of the reductants used or whether the melt pool was bubbled or not the DWPF cold cap and vapor space combustion models together predicted the $\mathrm{H}_{2}$ and CO data taken during the RSM and PSCM runs well, whose vapor space-tomelt pool cross-sectional area ratios and melt pool aspect ratios matched closely those of the DWPF melter. The exception was the RSM-LHH run whose estimated gas residence time was 1.1 second; however, it was shown that the DWPF models would predict the RSM-LHH data well when the gas residence time was increased to $\sim 3$ seconds, which indicates that the 1.1 second gas residence time may be outside the range of the current DWPF model for vapor space combustion.

It is also noted that both RSM and PSCM were run in the absence of active air purge defined as any air flow added intentionally in a controlled manner; therefore, the gas mixing in the vapor space was considerably less efficient than in the DWPF melter with an active air purge, as shown later in the CFD simulation. Indeed, the fact that the DWPF models were still able to adequately predict the data taken from these melters without active air purges underscores the importance of matching the DWPF melter cavity design parameters as closely as possible in order to achieve comparable overall combustion efficiencies.

On the other hand, the DWPF models were found to under predict the $\mathrm{H}_{2}$ and $\mathrm{CO}$ data taken from the DM10 and DM100, whose vapor space-to-melt pool cross-sectional area ratios and melt pool aspect ratios are markedly different from those of the DWPF melter, as shown in Table 5-19. It is noted that the DM10-SB6 data were taken with an estimated $10 \mathrm{scfm}$ of active air purge through a side port, which should have improved the gas mixing in the vapor space. However, the same active air purge also cooled the vapor space enough to stop any combustion of $\mathrm{H}_{2}$ and $\mathrm{CO}$. As a result, the DM10-SB6 data were used exclusively to check the applicability of the DWPF cold cap model and it was determined to be not applicable to the DM10-SB6 under the test conditions employed, i.e., formic acid reductant, non-bubbled, and active air purging. The DWPF cold cap model was also found to be not applicable to the DM10-A2 data taken under the test conditions opposite to those of the DM10-SB6, i.e., sugar reductant, bubbled, and without active air purge.

As far as the DM100-A2 run is concerned, since the calculated vapor space gas temperature was high enough for the combustion of $\mathrm{H}_{2}$ and $\mathrm{CO}$, its data were used to check the applicability of both the DWPF cold cap and vapor space combustion models, and they too were found to be not applicable as a set to the DM100-A2 data under the test conditions employed, i.e., formic acid reductant, bubbled, and without active air purge. The fact that the DWPF models under predicted the DM10 and DM100 data under diverse operating conditions seems to suggest that the degree of cold cap off-gas bypassing was greater in these melters than in the PSCM and RSM. Since gas bypassing in the cold cap is an integral part of slurry-fed melters, increased gas bypassing here simply means that the cold cap behavior of the DM10 or DM100 deviated more from the ideallystaged thermodynamic equilibrium modeling construct shown in Figure 4-1, and the degree of deviation may be more design related rather than operational. So, the higher vapor space-to-melt pool cross-sectional area ratio, the more radiant heat the cold cap is likely to receive and, as a result, the cold cap residues are forced to flux faster into the melt, thereby leaving less time for the decomposition products to fully equilibrate. In fact, gas bypassing formed an essential part of the cold cap model which was developed earlier using the data from the DM10 sub-Envelope A1 run in support of the WTP LAW melter off-gas flammability safety analysis. ${ }^{19}$

It is noted that the vapor space-to-melt pool cross-sectional area ratios and the melt pool aspect ratios of the SCM-2 and 774-A lie somewhere between those of the DWPF melter and those of the DM10 and DM100. So, based on the postulation that the melter internal design parameters are 
the key to achieving comparable overall combustion efficiency in differently scaled melters, the applicability of the DWPF models to the SCM-2 and 774-A runs was expected to be less robust than it was for either the RSM or PSCM. However, it was the data from the former melter runs against which the DWPF models were validated systematically. Specifically, the DWPF cold cap model was validated first against the "low-temperature" data taken from the SCM-2 and 774-A melters, and the cold cap and the vapor space combustion models were then validated together as a set against the "high-temperature" data. It means that both the SCM-2 and 774-A melters performed as well as other more prototypic melters in terms of burning off flammable gases in the cold cap as well as in the vapor space. One common feature of the SCM-2 and 774-A runs is that both melters were run in the presence of active air purge into the vapor space. In order to gain further insights into the impacts of active air purge as well as melter cavity design on the vapor space combustion efficiency such as gas mixing, a CFD simulation study was performed next.

\subsection{CFD Simulation of Gas Mixing}

The three-dimensional CFD modeling software called FLUENT ${ }^{\circledR} 6.3$ was used to evaluate the gas flow and mixing patterns in the melter vapor space under various design and operating conditions. ${ }^{30}$ A steady-state approach was taken to compute flow fields driven by the upward flows of steam and calcine gases from the cold cap and the downward air purge and/or inleakage flow from the lid. For the modeling calculations, three-dimensional steady-state momentum and continuity equations coupled with air and steam species transport formed the basic governing equations to estimate fluid motion. Gas flow regime conditions were determined by estimating the Reynolds number corresponding to the modeling conditions. The modeling conditions for the given inlet gas flows and inlet diameters correspond to the fully-turbulent flow regime, i.e., $\mathrm{Re}$ $\approx 10,000$. Therefore, a standard two-equation turbulence model, referred to as the $k$ - $\varepsilon$ model in the literature, was used to capture turbulent eddy motion.

\subsection{Bases and Assumptions}

In order to limit the heavy computational loads demanded by a CFD simulation involving species transport to a more manageable level, several simplifying assumptions were made and they are listed next along with some key bases for the calculations.

\subsubsection{Modeling Assumptions and Bases}

- All gas flow rates are constant - steady state.

- The entire modeling domain including the gas flows is kept isothermal at $100^{\circ} \mathrm{C}$. This effectively removes from consideration energy transport including radiative heat transfer between complex solid surfaces and through gas medium.

- There is no reaction between the cold cap gases and air, i.e., no combustion.

- The melter cavity is void of any internals such as vapor space heaters, thermowells, etc.

- Two-equation turbulence model is applicable to capturing the gas vortex behavior.

- Species transport equation is used to represent the mixing between the cold cap gases and air purge and/or inleakage in the vapor space.

\subsubsection{Modeling Domain}

The geometric configurations for the modeling domain are shown in Figure 6-1. Each schematic represents the vapor space of a particular melter type with the inlet flows of steam and calcine gases from the cold cap (denoted by the red arrows) and air purge and/or inleakage either from the backup film cooler or uniformly all across the lid (denoted by the blue arrows). The melter exhaust flow through the primary film cooler is denoted by the green arrows. Specifically, Figure 6-1a represents a scaled DWPF melter vapor space, 6' in diameter and 40" tall. Both inlet and outlet ports in the lid and are 5.5" I.D representing the actual I.D. of the primary and backup film 
coolers denoted by a blue dot and a chimney, respectively. The blue bottom face represents the cold cap at $100 \%$ coverage emitting steam and calcine gases uniformly all across the bottom face.

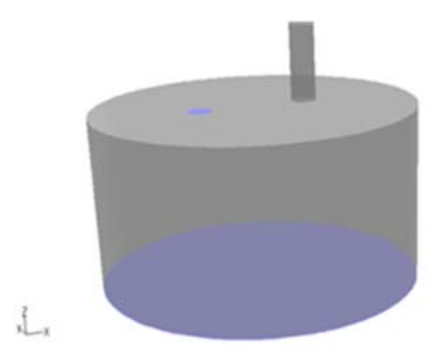

(a) DWPF

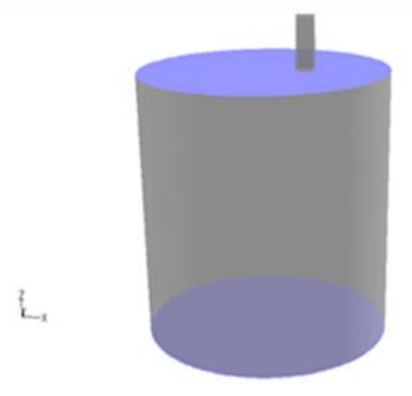

(c) CEF w/o Active Air Purge

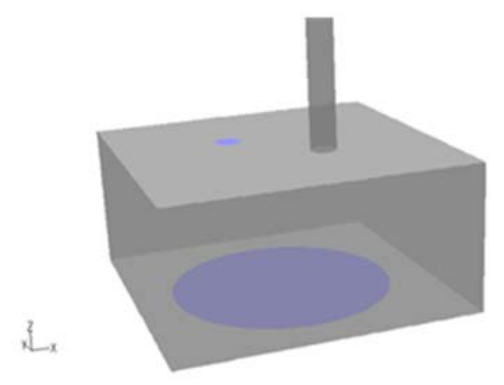

(e) $774-\mathrm{A}$

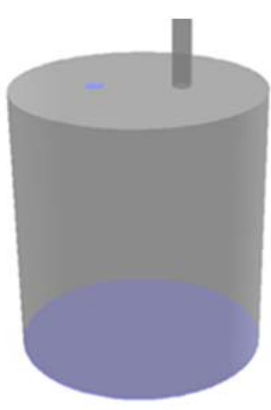

(b) CEF

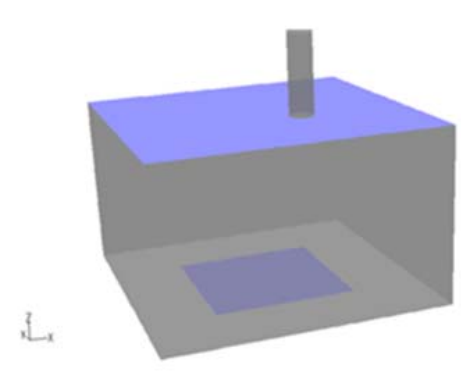

(d) DM100

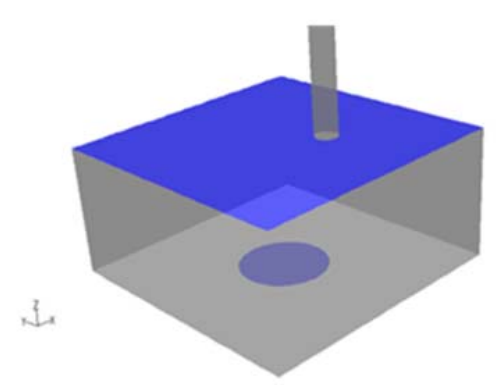

(f) $774-\mathrm{A} 20 \%$

Figure 6-1. Geometric Configurations of CFD Modeling Domain.

The remaining figures represent the indicated melter vapor space but scaled up to the DWPF dimensions. For example, the CEF vapor space shown in Figure 6-1b has the same diameter but twice as long a height as the DWPF melter vapor space. Likewise, the DM100 vapor space shown 
in Figure 6-1d has the same height and the same cross-sectional area (but in a square form) as the DWPF melter vapor space. However, the DM100 cold cap is set at $1 / 4$ of the DWPF (also in a square form) to show the vapor space-to-melt pool cross-sectional area ratio of 4 , which falls between the actual ratio of 3.3 and that of the DM10. Likewise, Figure 6-1e represents the 774-A melter vapor space with a circular cold cap at $100 \%$ coverage. It also has the same cross-sectional area as the DWPF melter vapor space but in a square form and has a lower height of $0.79 \mathrm{~m}$ to represent its vapor space aspect ratio of 2.4, somewhat smaller than the actual ratio of 2.9. Figure 6-1f also represents the 774-A melter vapor space but the difference is that the cold cap size is now reduced to $20 \%$ of that in Figure 6-1e, thus representing $20 \%$ cold cap coverage, which was indeed the maximum sustainable value during the 774-A melter run described earlier in Section 4.1.2.

\subsubsection{Baseline Gas Flow Rates}

The Level-1 calculation on the DWPF melter off-gas flammability assessment for the Slurry-Mix Evaporator (SME) Batch 563 formed the basis for all the mass flows. ${ }^{31}$ At the design basis glass production rate of $228 \mathrm{lb} / \mathrm{hr}$, the calcine gas flow rate was calculated to be $46 \mathrm{lb} / \mathrm{hr}$, consisting mostly of $\mathrm{H}_{2} \mathrm{O}$ at $43 \mathrm{wt} \%$ and $\mathrm{CO}_{2}$ at $34 \mathrm{wt} \%$. However, the upward gas flow is dominated by the steam generated from the free $\mathrm{H}_{2} \mathrm{O}$ in the feed at $350 \mathrm{lb} / \mathrm{hr}$. The composite molecular weight of the calcine gases and steam was calculated to be 18.7; therefore, the gases rising from the cold cap were assumed to be $100 \%$ steam and its volumetric flow rate was calculated to be $2.88 \mathrm{ft}^{3} / \mathrm{s}$ at $100^{\circ} \mathrm{C}$ for all cases except for the 774-A $20 \%$ case, where the volumetric flow rate was reduced by a factor of 5 .

The sum of air purges and inleakage was calculated to be $333 \mathrm{lb} / \mathrm{hr}$ by summing up the current feed interlock value of $263 \mathrm{lb} / \mathrm{hr}$ for the backup film cooler air before the instrument uncertainties, $20 \mathrm{lb} / \mathrm{hr}$ of seal pot purge, and $50 \mathrm{lb} / \mathrm{hr}$ of air inleakage. Therefore, the volumetric rate of air was calculated to be $1.56 \mathrm{ft}^{3} / \mathrm{s}$ at $100^{\circ} \mathrm{C}$ and 1 bar and was constant in all cases. The corresponding linear velocities of steam and air were then calculated for each geometric configuration depending on the size of each inlet. All the calculated flow rates and linear velocities of steam and air are summarized in Table 6-1.

Table 6-1. Gas Flow Rates at $100^{\circ} \mathrm{C}$ and 1 Bar Used in the CFD Modeling.

\begin{tabular}{|c|c|c|c|c|c|c|}
\hline \multirow{2}{*}{ Cases } & \multicolumn{2}{|c|}{ Steam Inlet } & \multicolumn{2}{|c|}{$\begin{array}{l}\text { Air Purge \& } \\
\text { Inleakage }\end{array}$} & \multirow{2}{*}{$\begin{array}{l}\text { Mode of } \\
\text { Air Inlet }\end{array}$} & \multirow{2}{*}{$\begin{array}{c}\text { Vapor } \\
\text { Space } \\
\text { Height } \\
\text { (m) }\end{array}$} \\
\hline & $\left(\mathrm{ft}^{3} / \mathrm{sec}\right)$ & $(\mathrm{ft} / \mathrm{sec})$ & $\left(\mathrm{ft}^{3} / \mathrm{sec}\right)$ & $(\mathrm{ft} / \mathrm{sec})$ & & \\
\hline DWPF & 2.88 & 0.10 & 1.56 & 9.45 & Jet & 1.0 \\
\hline $\mathrm{CEF}$ & 2.88 & 0.10 & 1.56 & 9.45 & Jet & 2.0 \\
\hline CEF w/o active air purge & 2.88 & 0.10 & 1.56 & 0.06 & Dispersed & 2.0 \\
\hline DM100 & 2.88 & 0.41 & 1.56 & 0.06 & Dispersed & 1.0 \\
\hline 774-A & 2.88 & 0.23 & 1.56 & 9.45 & Jet & 0.79 \\
\hline 774-A $20 \%$ & 0.58 & 0.23 & 1.56 & 0.06 & Dispersed & 0.79 \\
\hline
\end{tabular}




\subsection{Governing Equations for Gas Species Transport in Turbulent Flow}

When chemical reaction is neglected, steady state conservation equation for air species is governed by:

$$
\nabla \cdot\left(\rho \vec{v} Y_{a}\right)=-\nabla \cdot \vec{J}_{a}+S_{a}
$$

where $Y_{a}$ is local mass fraction of air in the continuous vapor, $\vec{J}_{a}$ is the diffusion flux of vapor species, $S_{a}$ is a source term of air species added to the vapor, which is zero in this case. The diffusion flux of air under turbulent vapor flow is computed by:

$$
\vec{J}_{a}=-\left(\rho D_{a}+\frac{\mu_{t}}{S c_{t}}\right) \nabla Y_{a}
$$

where $D_{a}$ is the molecular diffusion coefficient of air in the continuous vapor medium. For the present calculations, the parameters $D_{a}$ and $S c_{t}$, are assumed to be $3.0 \times 10^{-5} \mathrm{~m}^{2} / \mathrm{sec}$ and 0.7 , respectively.

The present analysis used the two-equation turbulence model known as $k$ - $\varepsilon$ model in the literature. In this model, transport equations are solved for two turbulence quantities, $k$ and $\varepsilon$. Turbulence kinetic energy $(k)$ is the mean kinetic energy per unit mass associated with eddies in turbulent flow. Physically, the turbulence kinetic energy is characterized by measured root-mean-square (rms) velocity fluctuations. From two key turbulence parameters of $\kappa$ and $\varepsilon$ a quantity of turbulent eddy diffusivity $\left(\kappa^{2} / \varepsilon\right)$, can be formed without specification of flow-dependent mixing length scale $\lambda .^{32}$ The turbulent energy transport term $T^{\prime}$ is modeled with a gradient-diffusion hypothesis:

$$
T^{\prime}=-\frac{v_{T}}{\sigma_{k}} \nabla k
$$

where the turbulent Prandtl number for kinetic energy is generally taken to be $\sigma_{k}=1.0$. This equation assumes that there is a flux of $k$ down the gradient of $k$ due to velocity and pressure fluctuations. In summary, the transport equation for turbulent kinetic energy $k$ is:

$$
\frac{D k}{D t}=\nabla \cdot\left(\frac{v_{T}}{\sigma_{k}} \nabla k\right)+P-\varepsilon
$$

where $D k / D t$ is the mean-flow convection of $k, T^{\prime}$ the turbulent transport, $P$ the production of $k$, and $\varepsilon$ is the turbulent kinetic energy dissipation rate. The action of the mean velocity gradients working against the Reynolds stresses removes the kinetic energy from the mean flow and transfers it to the fluctuating velocity field as energy production term $P$.

Turbulence consists of high levels of fluctuating vorticity. At any instant, vortical motion called eddies are present in the flow. These eddies range in size from the largest geometric scales of the flow such as tank diameter down to the smallest eddies where molecular diffusion dominates. Regardless of size, eddies are continuously evolving, and the superposition of their induced motions leads to the fluctuating waves. In this situation, turbulent kinetic energy is dissipated from the largest eddies down to the smallest through a process called energy cascade. In order to maintain the turbulence, a constant supply of energy must be fed to the turbulent fluctuations at the largest scales from the mean motions, where it is driven by a jet pump or mechanical agitator. 
Thus, turbulent energy dissipation rate $\varepsilon$ is viewed as the energy-flow rate in the cascade, and it is determined by the large-scale motions, independent of the viscosity at high Reynolds number. Consequently, the transport equation for $\varepsilon$ is best considered as being entirely empirical. That is,

$$
\frac{D \varepsilon}{D t}=\nabla \cdot\left(\frac{v_{T}}{\sigma_{\varepsilon}} \nabla \varepsilon\right)+C_{1}\left(\frac{\varepsilon}{k}\right) P-C_{2} \frac{\varepsilon^{2}}{k}
$$

where the turbulent viscosity is:

$$
v_{T}=C_{\mu} \frac{k^{2}}{\varepsilon}
$$

where $C_{\mu}=0.09$. It is noted that the turbulent viscosity coefficient $C_{\mu}$ of 0.09 in the two-equation model, Eq. (18), can be derived under the log-law. ${ }^{33}$ From these results, the two-equation turbulence model is good for the bulk model including the log-law shear region, but it will not be good for the flow within the laminar sub-layer close to the wall, as shown in the previous work. ${ }^{34}$

\subsection{Results of CFD Modeling}

The results of the CFD modeling of gas flows and mixing in the six geometric configurations shown in Figure 6-1 are presented. Since isothermal conditions were assumed, the results do not reflect any buoyancy effects.

\subsubsection{Case: $D W P F$}

A vector plot of model predicted gas velocities along the center-cut vertical plane of the DWPF melter vapor space is shown in Figure 6-2. The most striking feature of this figure is that the air purge discharging from the backup film cooler at the mean velocity of $9.45 \mathrm{ft} / \mathrm{sec}$ forms a jet impinging on the cold cap. Although steam enters the vapor space at only $0.1 \mathrm{ft} / \mathrm{sec}$, almost two orders of magnitude lower than the air, nearly $50 \%$ of it is shown to be accelerated by the jet via entrainment. As a result, two large swirling eddies are shown on each side of the expanding jet. The highest gas velocity was calculated to be $\sim 27 \mathrm{ft} / \mathrm{sec}$ at the exit port where steam and air flows are converging, as indicated by the darkest red color. As expected, the gas velocities remain low at the opposite side of the jet. Since the gas velocities vary by more than two orders of magnitude from 0.1 to $27 \mathrm{ft} / \mathrm{sec}$, the given color codes of gas velocity in Figure 6-2 are only for up to $1 \mathrm{ft} / \mathrm{sec}$ in order to better discern the regions of low velocities and therefore poor mixing. 

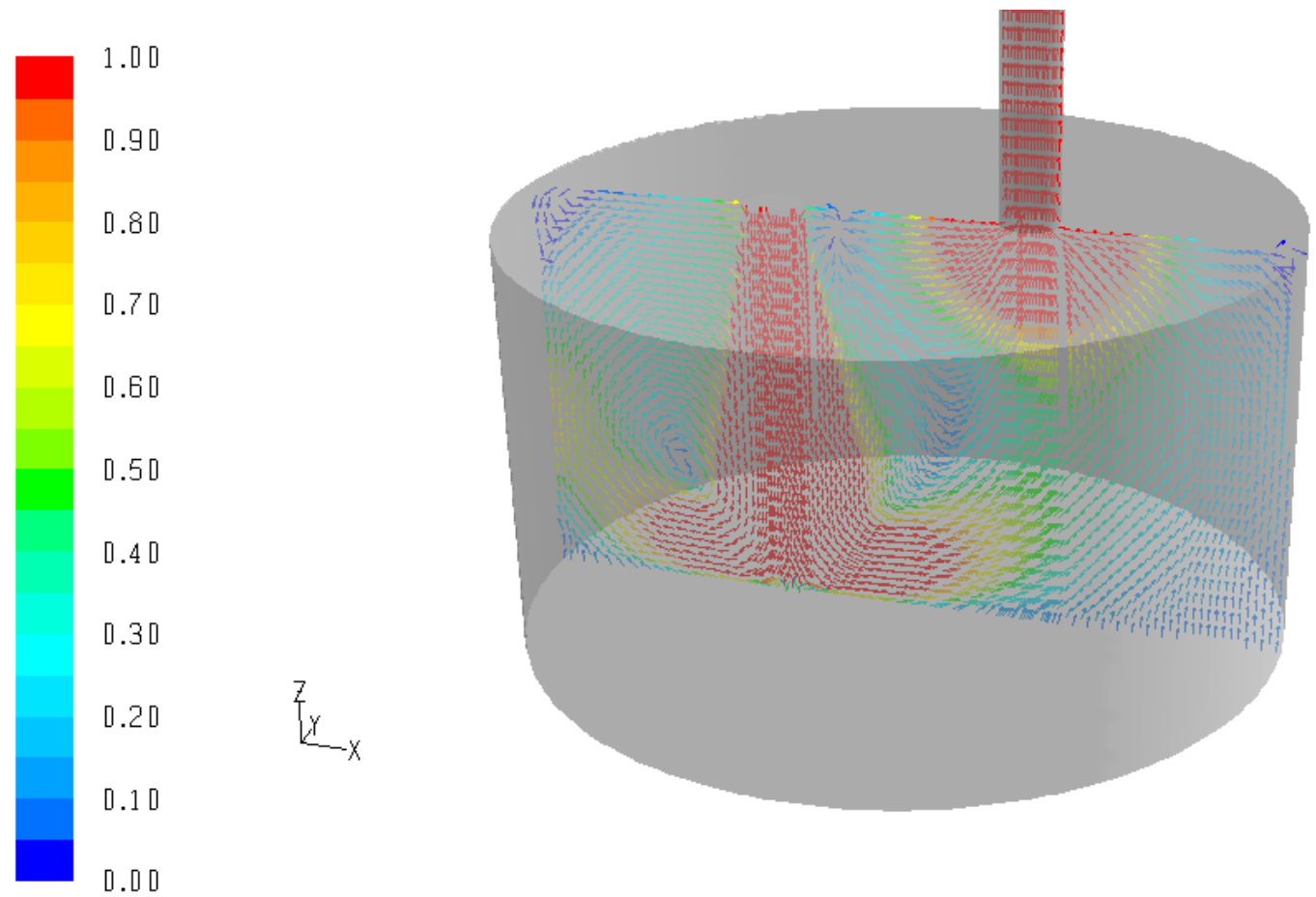

Figure 6-2. Vertical Center-Cut Vector Plot of Gas Velocities in ft/sec (Case: DWPF).

Figure 6-3 shows how well gases are mixed in the vapor space. Since the given color codes are based on the mass fraction of steam, the volumetric flow rates given in Table 6-1 were converted into the mass flow rates using 0.59 and $0.037 \mathrm{lb} / \mathrm{ft}^{3}$ as the density of air and steam, respectively, at 1 bar and $100^{\circ} \mathrm{C}$. So, when steam and air flows are perfectly mixed, the resulting mixture will have $54 \%$ steam and $46 \%$ air or a color code of 0.54 (medium green) for all cases except for Case 774-A 20\%, where perfect mixing is represented by a color code of 0.19 (medium blue). The vertical center-cut view (upper) of Figure 6-3 clearly shows the expanding air jet impinging on the cold cap by entraining the surrounding gases for better mixing, compared to the regions away from the jet toward the walls. As gases travel closer to the exit, mixing improves considerably, as expected. The horizontal center-cut view (lower) also shows good mixing all across the area. Since air is provided in large excess, there will be no shortage of oxygen at color codes up to $\sim 0.8$. 

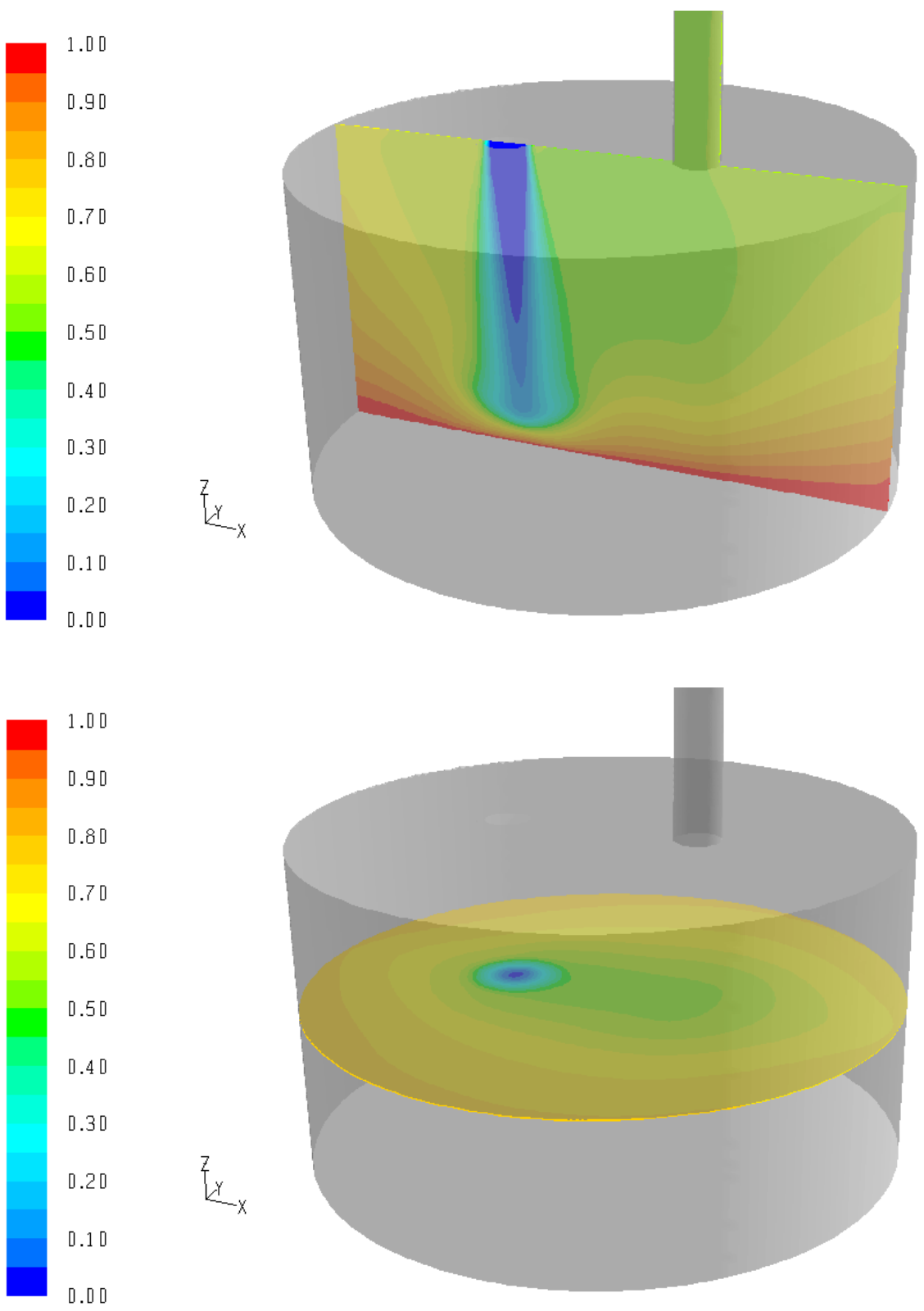

Figure 6-3. Center-Cut Views of Gas Mixing in Mass Fractions (Case: DWPF).

\subsubsection{Case: $C E F$}

A vector plot of gas velocities along the center-cut vertical plane of the CEF vapor space is shown in Figure 6-8. As in Case DWPF, the air entering the vapor space through the backup film cooler at the mean velocity of $9.45 \mathrm{ft} / \mathrm{sec}$ forms a jet impinging on the cold cap. Although the jet travels twice the distance of Case DWPF, it still retains enough momentum to form high-velocity radial gas flows at the impact particularly in the direction closer to the walls. Well over $50 \%$ of the steam entering the vapor space is shown to be accelerated by the jet via entrainment. As a result, two large swirling eddies are shown on either side of the expanding jet. As expected, the overall velocity profile is quite similar to that of Case DWPF. 
The vertical center-cut view (upper) of Figure 6-5 clearly shows that as in Case DWPF, the air jet impinging on the cold cap expands by entraining the surrounding gases to induce better mixing. Due to its $2 \mathrm{X}$ height, the overall mixing efficiency in the CEF vapor space appears to be higher than Case DWPF. As gases travel toward to the exit at the top, mixing improves considerably particularly in the annulus region between the jet and the upper walls opposite to the exit port. The horizontal center-cut view (lower) also shows better mixing in the vicinity of the jet in the direction of the exit port, although the remaining cross-section is still well mixed, i.e., $60-80 \%$ steam and $20-40 \%$ air, and there will be no shortage of oxygen at such mixing ratios.
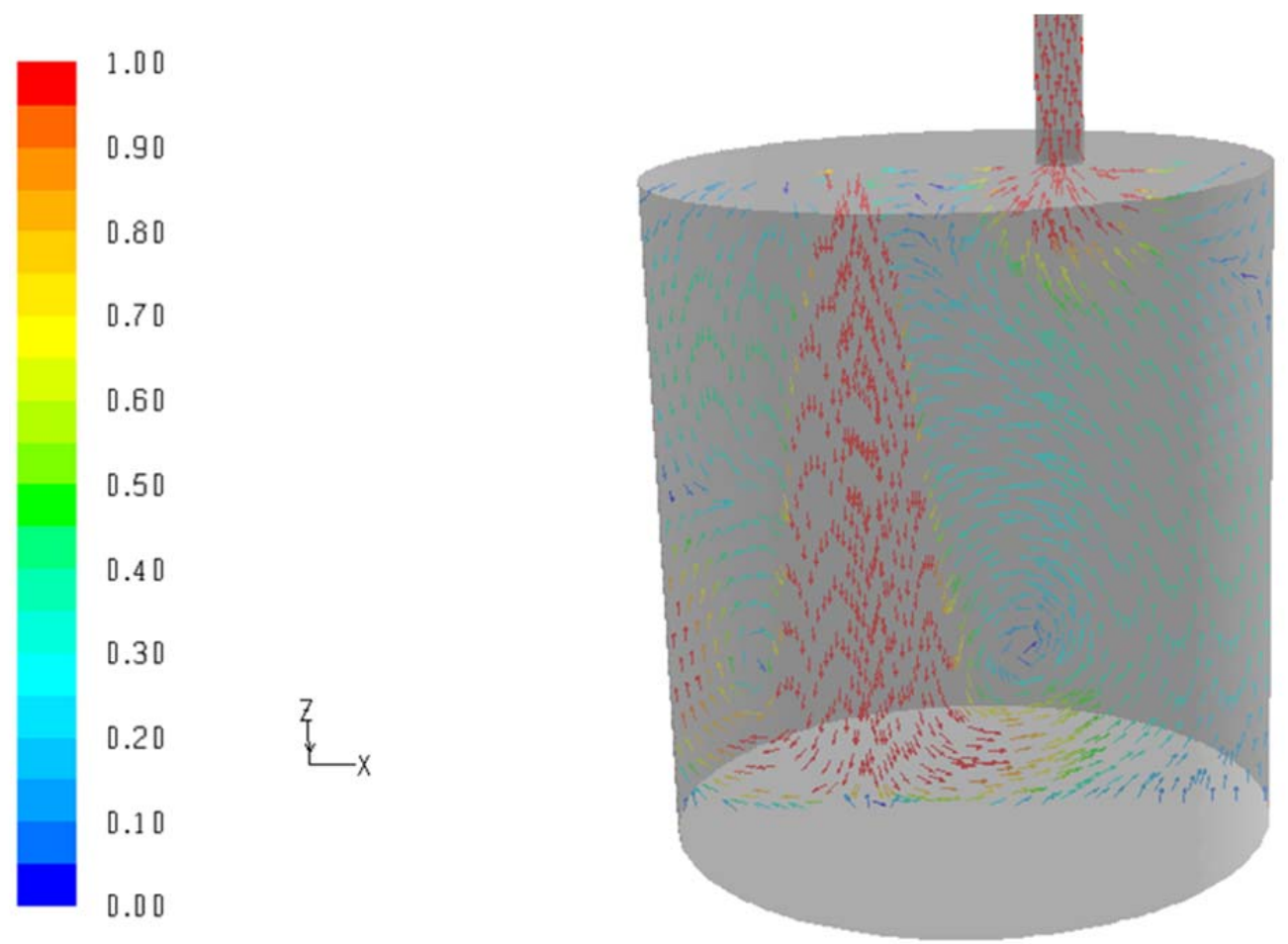

Figure 6-4. Vertical Center-Cut Vector Plot of Gas Velocities in ft/sec (Case: CEF). 
Revision 0

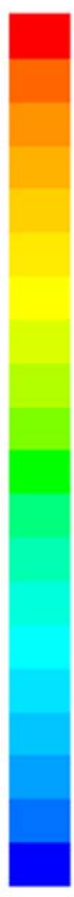

1.0

0.9

0.8

0.7

0.6

0.5

0.4

0.3

0.2

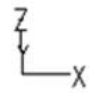

0.1

0.0
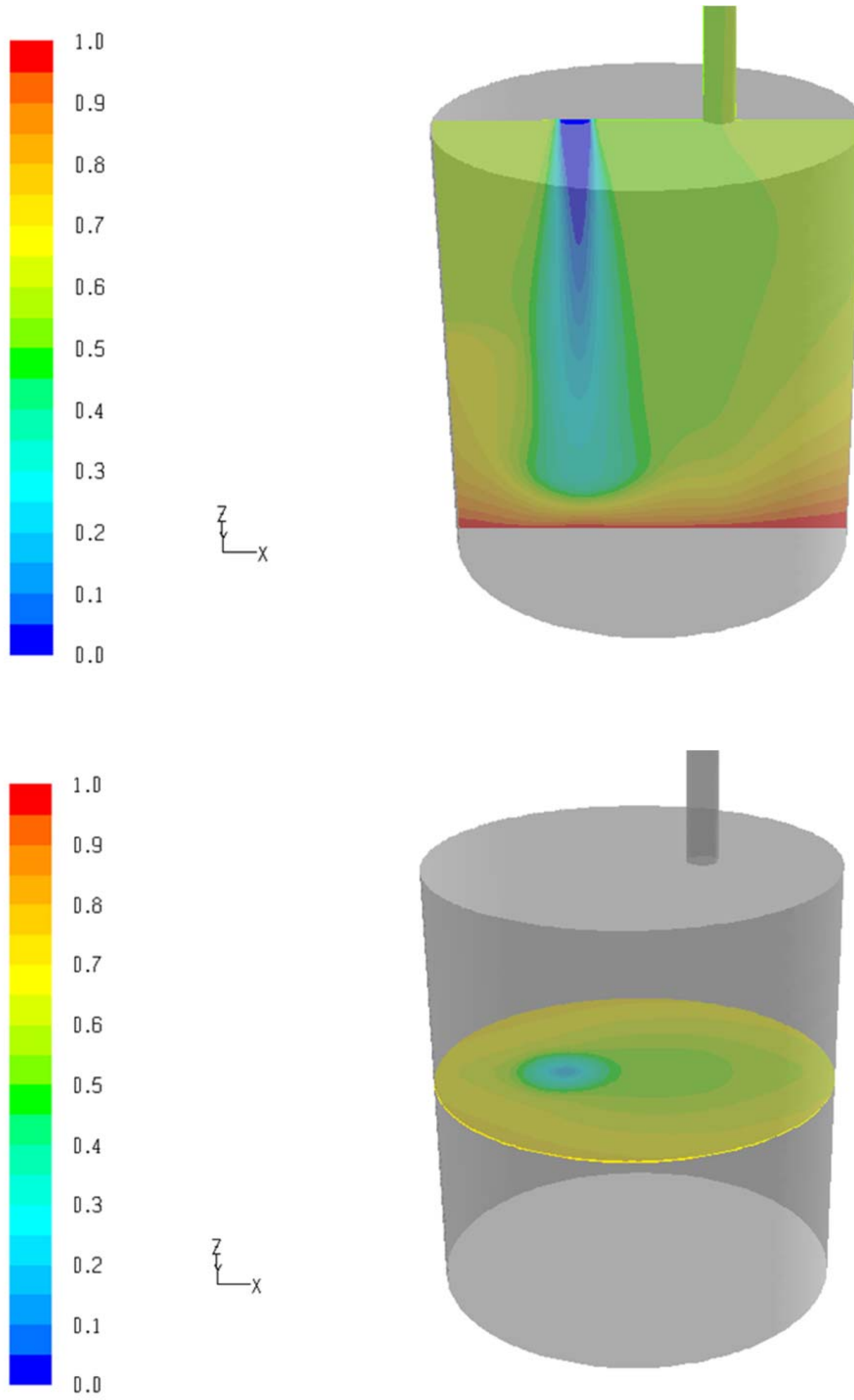

Figure 6-5. Center-Cut Views of Gas Mixing in Mass Fractions (Case: CEF). 


\subsubsection{Case: CEF w/o Active Air Purge}

A vector plot of gas velocities along the center-cut vertical plane of the CEF vapor space is shown in Figure 6-6. In this configuration, air enters the vapor space uniformly all across the lid so its velocity is reduced by more than two orders of magnitude from that of the DWPF case to only $0.06 \mathrm{ft} / \mathrm{sec}$. The velocity of steam remains the same as that of Case DWPF; however, it is now $\sim 2 \mathrm{X}$ higher than the air velocity. When the air and steam flows collide, they simply merge together and flow in the direction of the exit port. As a result, the flow fields are segregated between downward air flow and upward steam flow for much of the vapor space volume, until gases converge and accelerate through the exit port.

Figure 6-7 clearly shows how poor the gas mixing is in the CEF vapor space in the absence of active air purge. The vertical center-cut view (upper) clearly shows that much of the vapor space volume is occupied by the steam flow, while the air flow is confined only to the uppermost region. Such a poor mixing is the result of three conditions imposed on the system. First, the steam and air flows are coming from the opposite directions. Second, the upward velocity of steam is $\sim 2 \mathrm{X}$ higher than the downward velocity of air. Third, the exit port is located at the top. When the two flows collide, some mixing is shown to occur but along a narrow band of vapor space due to low velocities of air and steam. In fact, the velocities are so low that even the flow inside the exit port is shown to be stratified. As a result, much of the flammable gases would remain unburned regardless of temperature. It should be noted that the results shown in Figure 6-7 represent the bounding case for poor mixing, since in reality the air inleakage is more localized around the penetrations and flanges and therefore the air velocity will be considerably higher than considered here except for a very tight system.
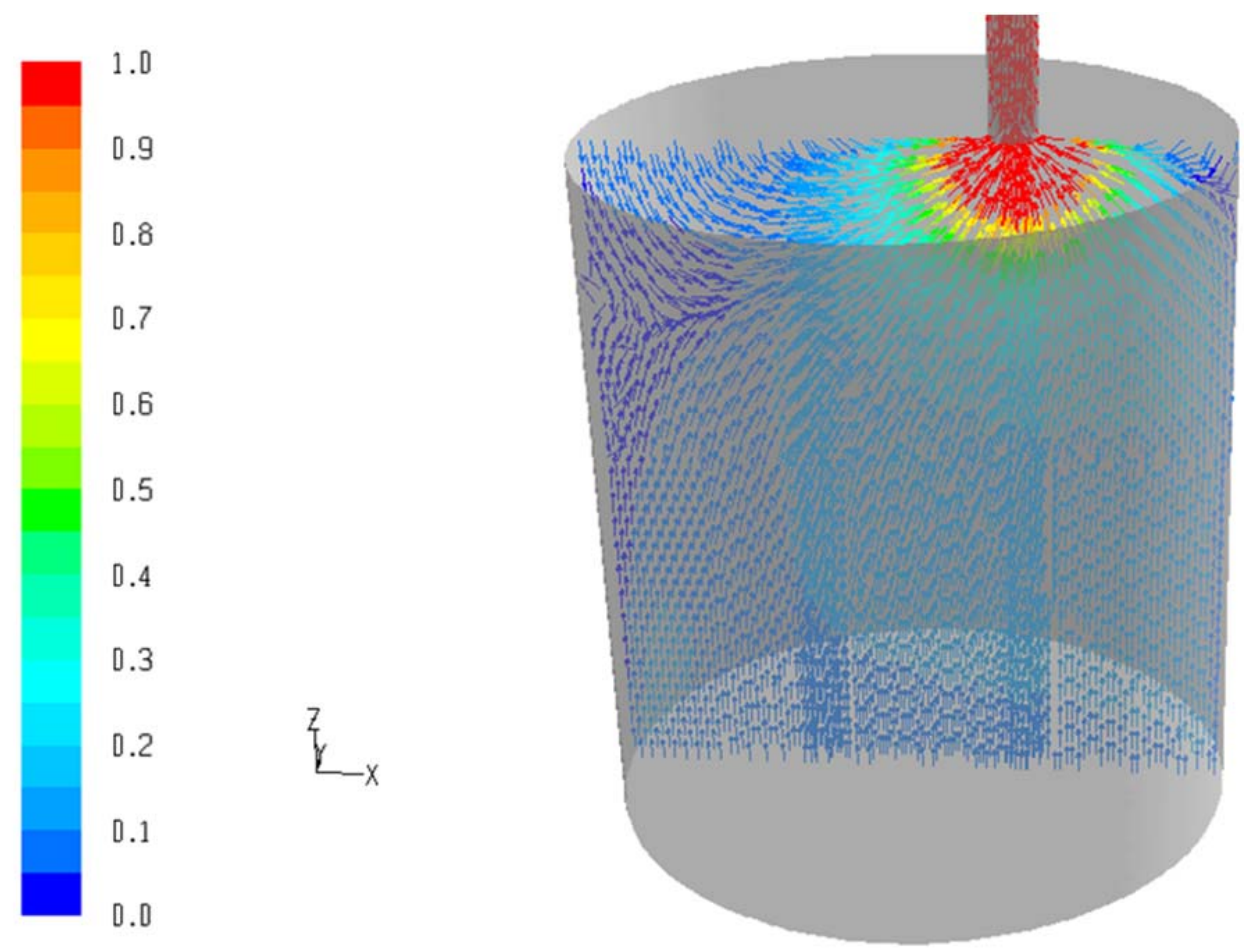

Figure 6-6. Vertical Center-Cut Vector Plot of Gas Velocities in $\mathrm{ft} / \mathrm{sec}$ (Case: CED w/o Active Air Purge). 
1.0

0.9

0.8

0.7

0.6

0.5

0.4

0.3

0.2

0.1

0.0

1.0

0.9

0.8

0.7

0.6

0.5

0.4

0.3

0.2

0.1

0.0
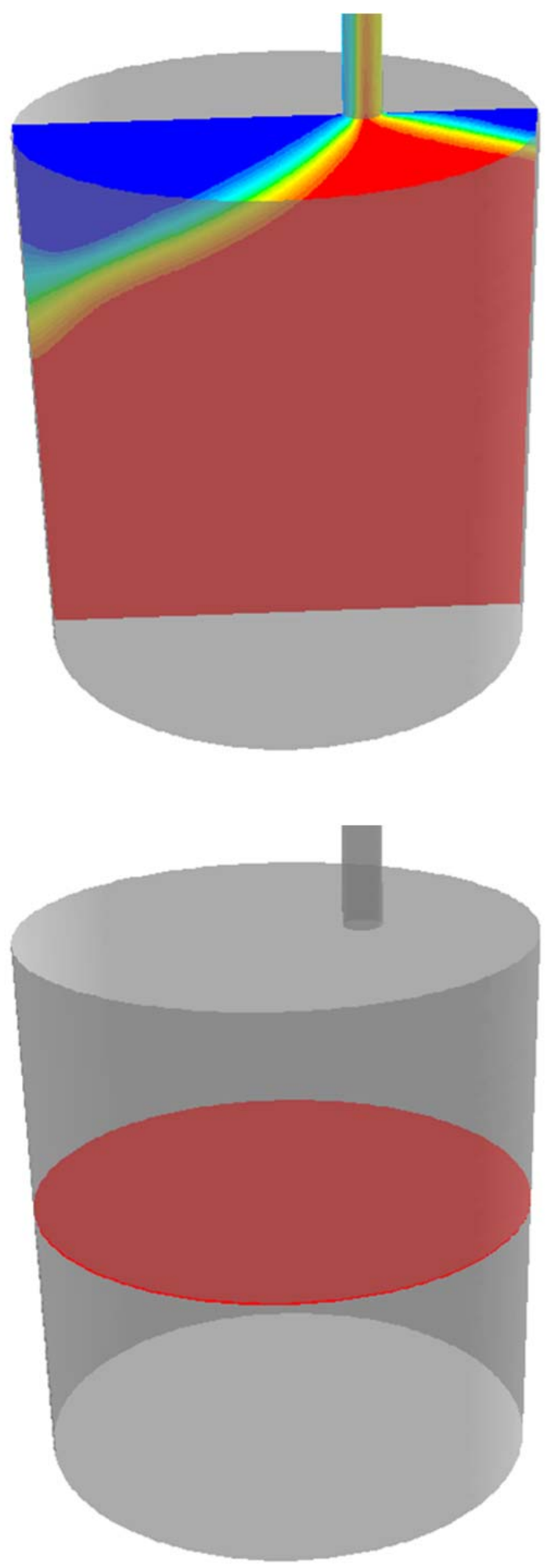

Figure 6-7. Center-Cut Views of Gas Mixing in Mass Fractions (Case: CEF w/o Active Air Purge). 


\subsubsection{Case: DM100}

A vector plot of gas velocities along the center-cut vertical plane of the DM100-type vapor space is shown in Figure 6-8. In this configuration, air enters the vapor space uniformly all across the square lid so its velocity is reduced by more than two orders of magnitude from that of the DWPF case to only $0.06 \mathrm{ft} / \mathrm{sec}$. On the other hand, the velocity of steam is now $4 \mathrm{X}$ higher than that of the DWPF case, since the cold cap surface is reduced by the same factor. However, the increased velocity of steam is still too low to form an upward jet; instead, it just pushes aside the air coming down and flows toward the exit port, while producing some mixing along its periphery. However, for much of the vapor space volume, the flow fields are totally segregated between downward air flow and upward steam flow, until they converge and accelerate at the exit port.

Figure 6-9 clearly shows how poor the gas mixing is in the DM100-type vapor space with no active air purge. Both center-cut views show that much of the steam rising from the center $25 \%$ of the bottom surface remains unmixed until very near the exit port. The flow field is shown to be stratified even in the exit port as in the Case CEF w/o active air purge. It is also shown that the gas mixing is particularly poor along the edges of the rectangular walls, which indicates that under comparable conditions the overall mixing efficiency in a cylindrical cavity should be higher than that in a rectangular cavity, as discussed in Section 4.2.1 with the DM1200-A1 data. Furthermore, although the CFD analysis is based on the isothermal assumption, the impact of melter cavity design on heat transfer can still be gleaned by comparing Figure 6-7 and Figure 6-9. Without active air purge, the bulk of the DM100-type vapor space is shown to be occupied by the air flow, whereas the CEF-type vapor space is occupied mostly with the steam flow. Noting that air purge is the main heat sink in the vapor space, it can easily be inferred that cooling due to air inleakage will be more significant in the DM100-type vapor space than in the CEF-type vapor space. It is well known that cooling of the vapor space by active and/or passive air purge not only lowers the overall combustion efficiency but reduces the glass production rate greatly.
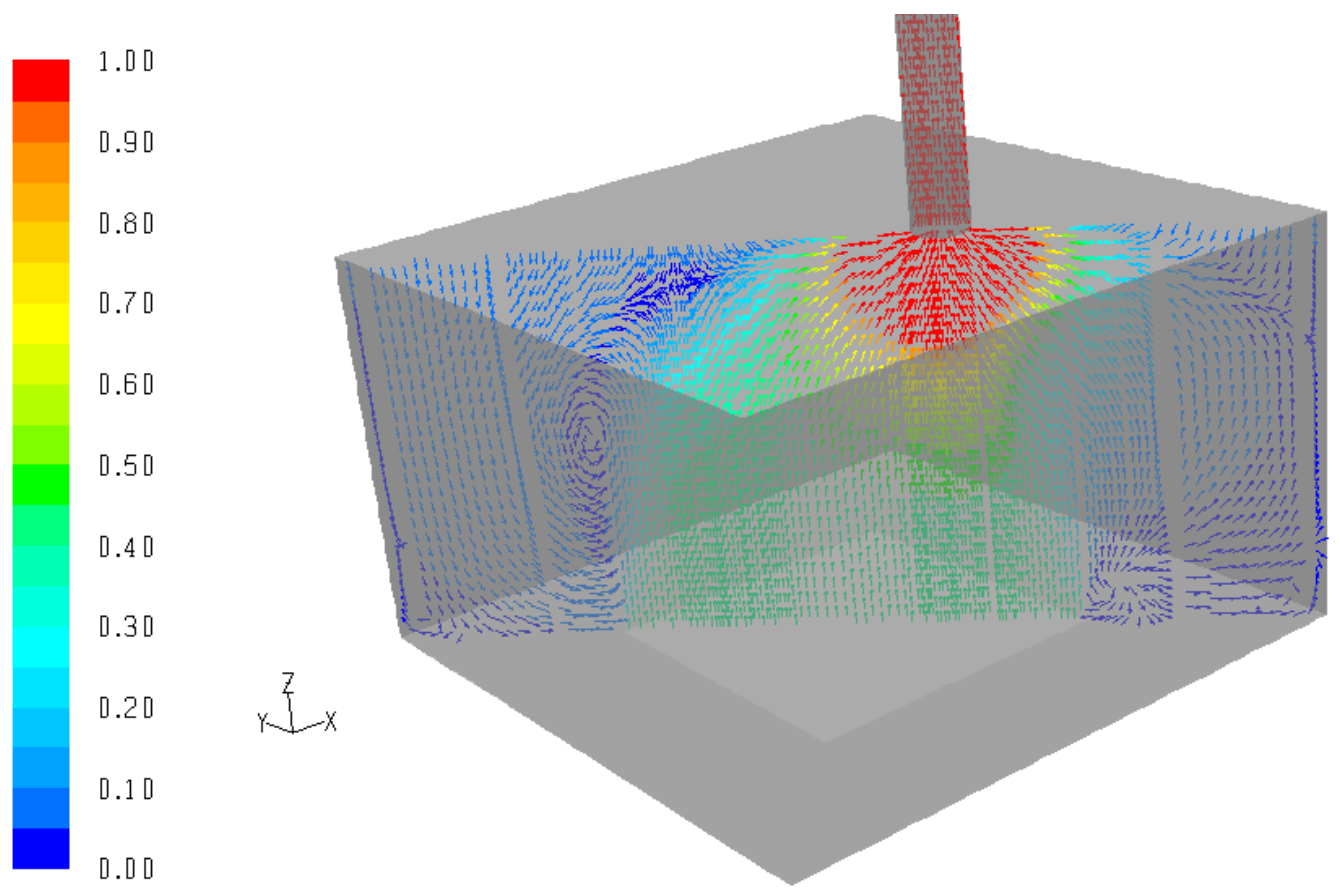

Figure 6-8. Vertical Center-Cut Vector Plot of Gas Velocities in ft/sec (Case: DM100). 


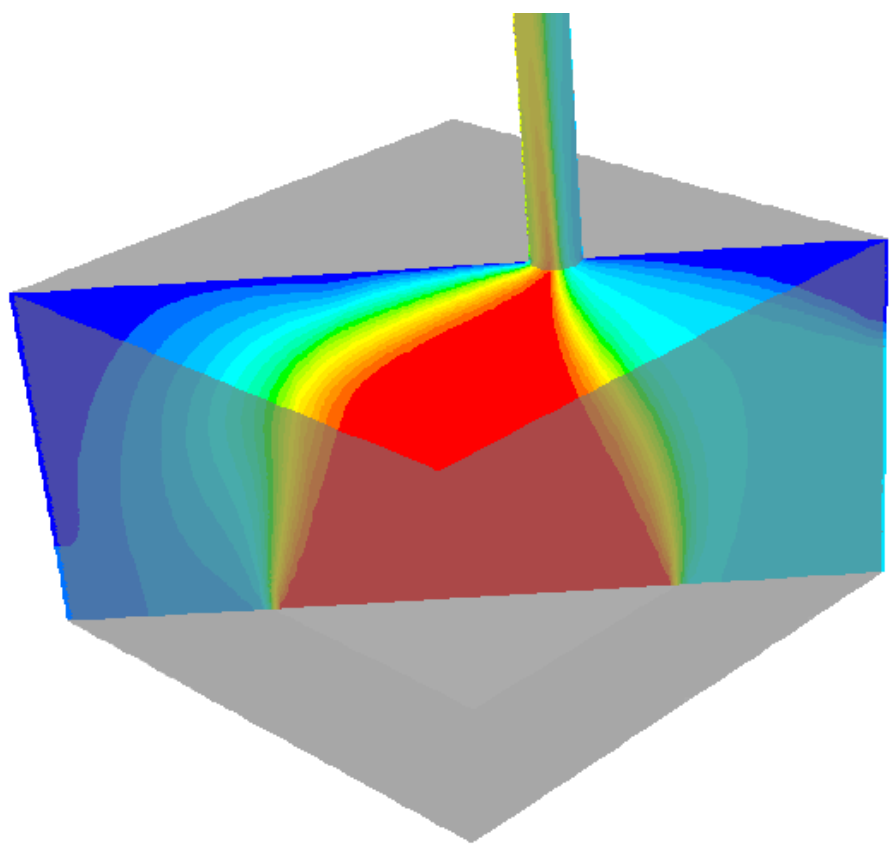

0.00
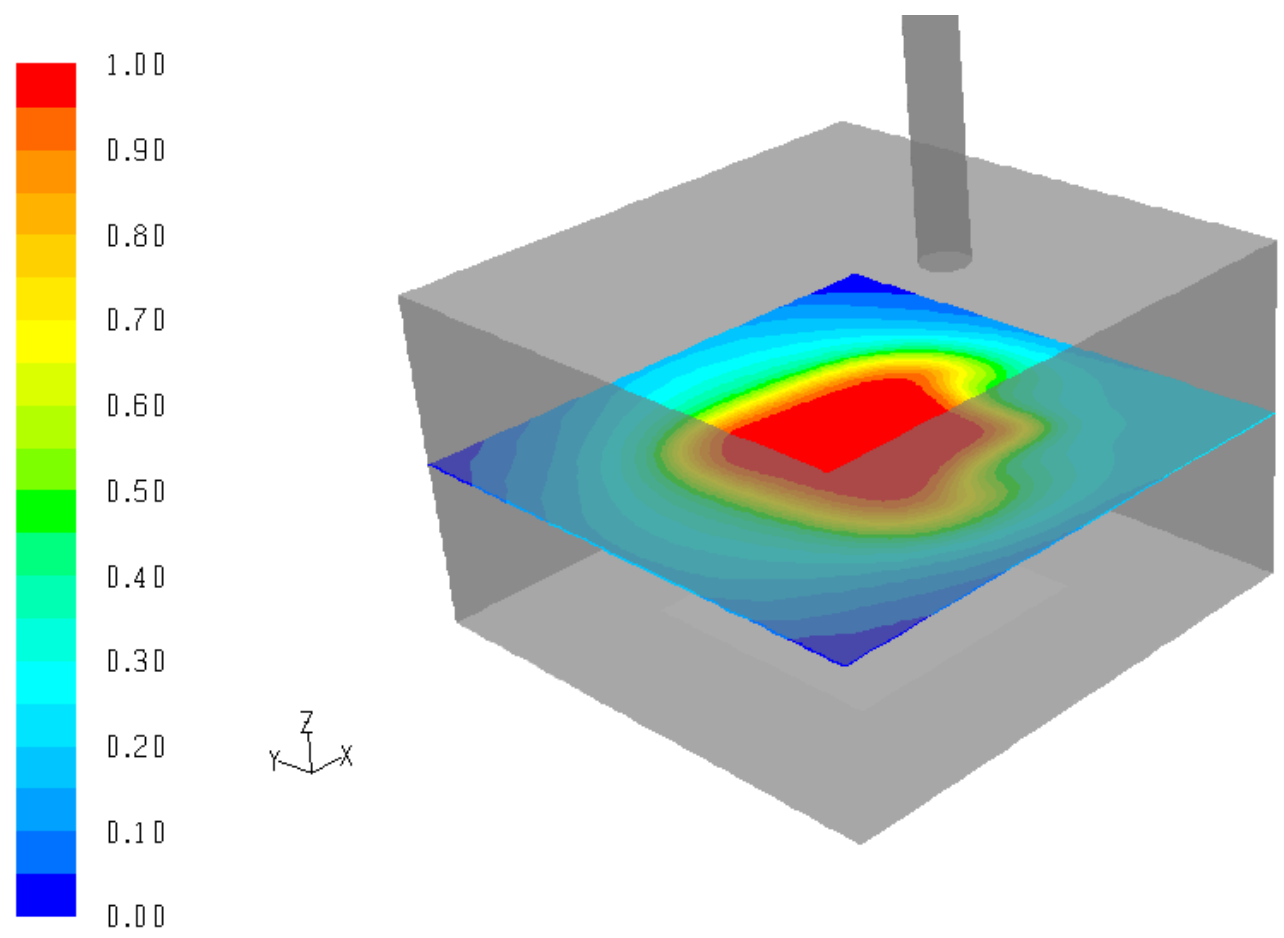

0.0.

Figure 6-9. Center-Cut Views of Gas Mixing in Mass Fractions (Case: DM100). 


\subsubsection{Case: 774-A Melter}

A vector plot of gas velocities along the center-cut vertical plane of the 774-A melter-type vapor space is shown in Figure 6-10. In this configuration, air discharges from the backup film cooler at $9.45 \mathrm{ft} / \mathrm{sec}$, thus forming just as strong a jet as that of the DWPF case. However, since the jet travels a shorter distance, it creates more turbulence as it impinges on the cold cap than in the DWPF case. As a result, the high velocity field of the deflected jet denoted by the red arrows is shown to continue almost to the exit port. Furthermore, the velocity of steam is $2.3 \mathrm{X}$ higher than that of the DWPF case, since its cold cap size is reduced by the same factor, i.e., the vapor spaceto-melt pool cross-sectional area is 2.3. As in the DWPF case, the highest gas velocity of $27 \mathrm{ft} / \mathrm{sec}$ occurs inside the exit port, as indicated by the darkest red color. It was expected that the gas velocities would remain low where the impact of the jet is the least, as shown in Figure 6-10.

Figure 6-11 shows that the overall mixing of gases in the 774-A melter-type vapor space is quite comparable to that of the DWPF case, if not better. Despite its non-prototypic cavity, the area of the steam-rich region denoted by the red color actually appears smaller than that of the DWPF case, since its cold cap size is less than $50 \%$ of that of the DWPF case. Thus, it seems reasonable to expect that when the cold cap size is further reduced by an additional factor of 5 to mimic the actual cold cap coverage of $20 \%$ during the $774-\mathrm{A}$ melter run, the area of the steam-rich region will appear even smaller and, therefore, the area of the well-mixed region will become larger. This may explain why the DWPF models bounded the measured $\mathrm{H}_{2}$ and $\mathrm{CO}$ data well, as shown in Figure 4-3 and Figure 4-4. In other words, the measured overall combustion efficiency of the 774-A melter was at least comparable to that of the DWPF melter, if not better. The horizontal center-cut view also shows that the region of perfect mixing is found not only near the jet but at the least-expected places, along the edges of the rectangular walls. The results of this case also explain why the overall combustion efficiency of the SCM-2 vapor space was comparable to that of the DWPF melter despite its non-prototypic cavity design.
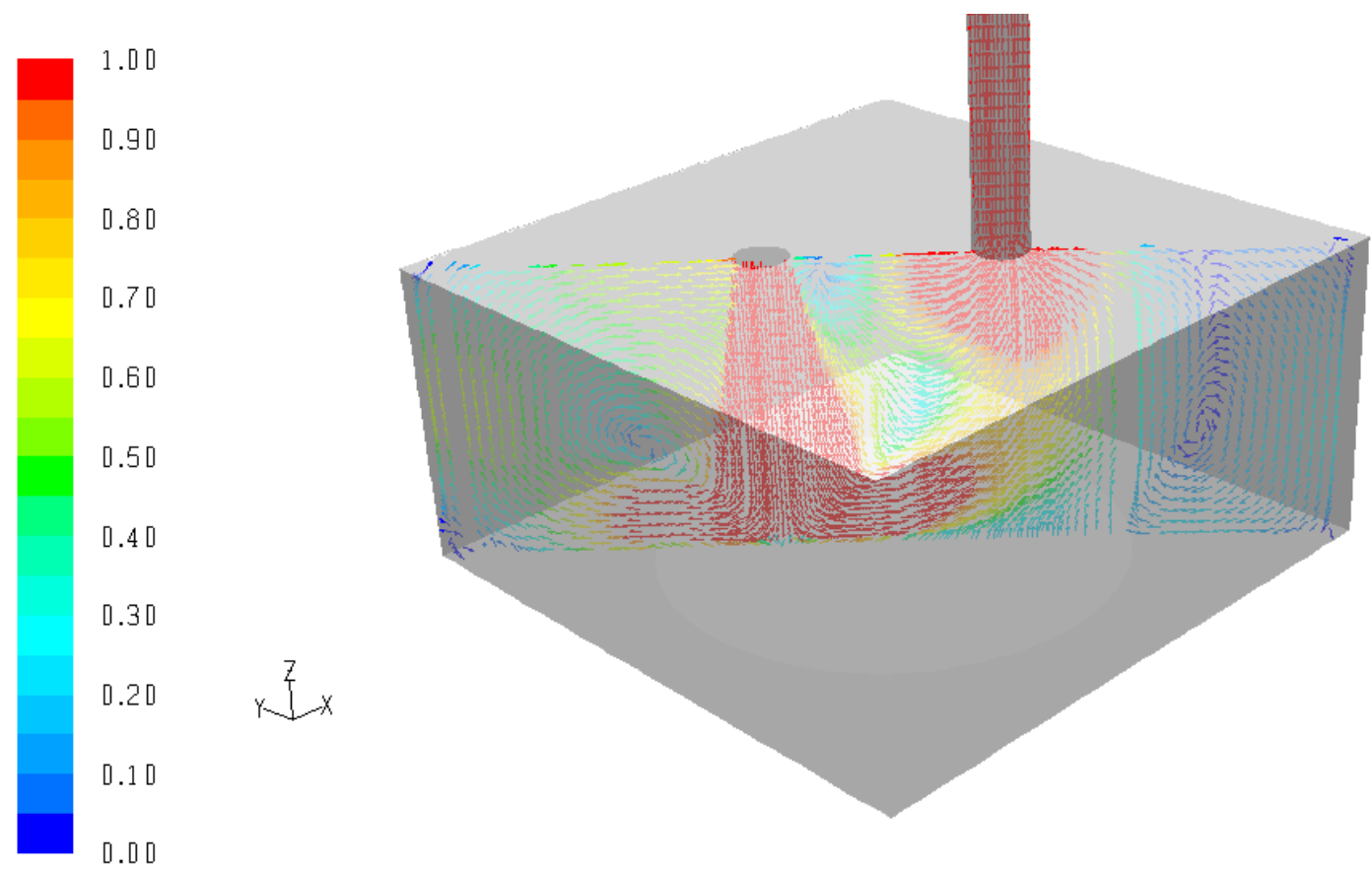

Figure 6-10. Vertical Center-Cut Vector Plot of Gas Velocities in ft/sec (Case: 774-A Melter). 

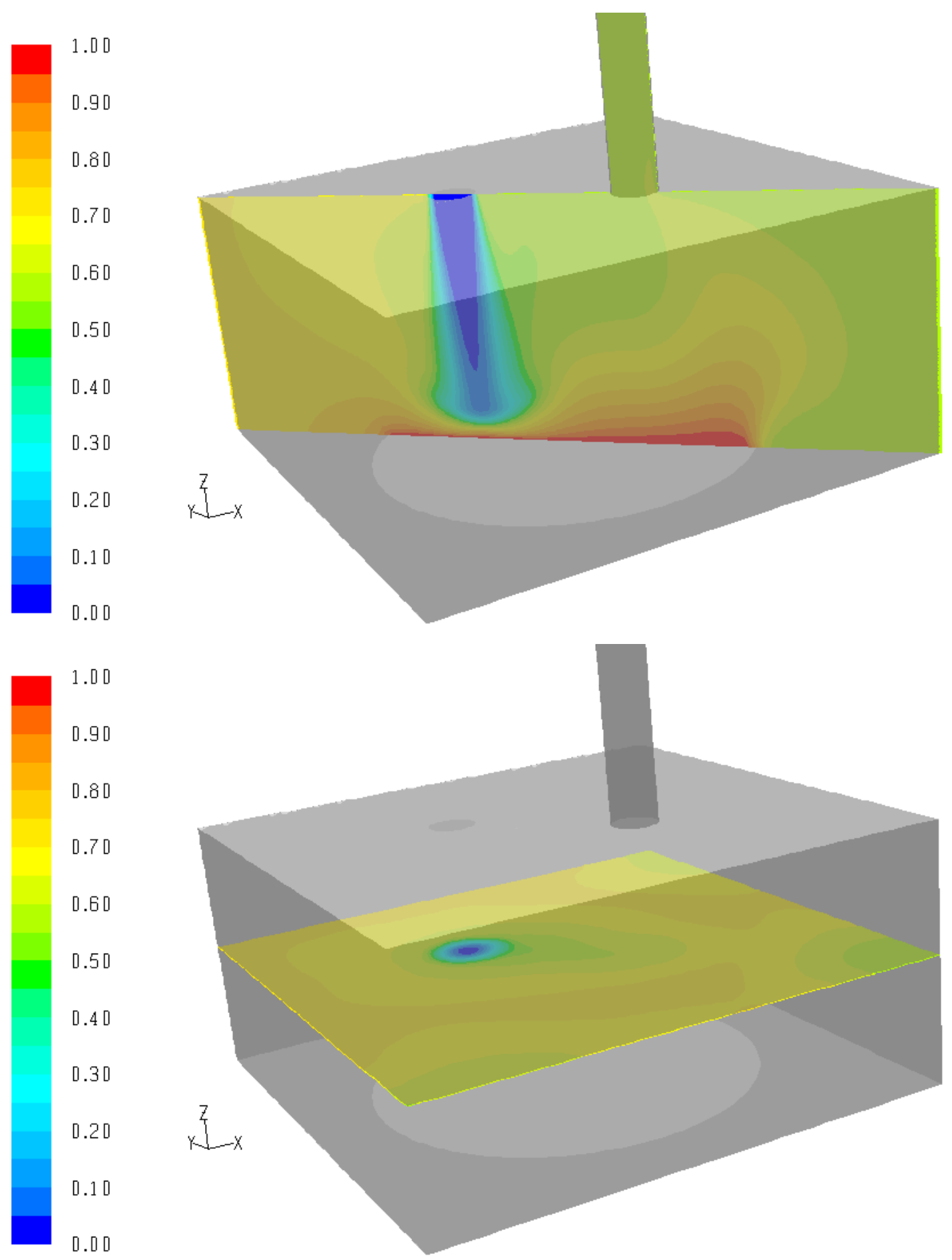

Figure 6-11. Center-Cut Views of Gas Mixing in Mass Fractions (Case: 774-A Melter). 


\subsubsection{Case: $774-$ A 20\%}

This case represents the 774-A melter with $20 \%$ cold coverage but without the active air purge. The purpose was to see whether the trend of shrinking area of the steam-rich or un-mixed region with decreasing cold cap size would still hold without the air jet. Therefore, as in the DM100 case, air trickles in all across the square lid at $0.06 \mathrm{ft} / \mathrm{sec}$, while the nominal steam flow at $100 \%$ cold cap coverage was reduced by a factor of 5 in order to maintain the same linear velocity of steam, thus reflecting steady state operation. The resulting vector plot of gas velocities along the centercut vertical plane is shown in Figure 6-12. As in the DM100 case, no eddies are found, indicating poor mixing.

Figure 6-13 shows that the overall mixing of gases is indeed very poor and actually even worse than Case DM100 or at $100 \%$ cold cap coverage. In fact, decreasing the cold cap coverage is like increasing the vapor space-to-melt pool cross-sectional area ratio, since they in essence reflect in the opposite direction the degree of expansion the cold cap gases go through as they enter the vapor space. At a cross-sectional area ratio somewhat larger than 1 or at high cold cap coverage, gases have to expand less and do so fairly well. At a cross-sectional area ratio significantly larger than 1 or at very low cold cap coverage, however, gases have to expand a lot but do so very little, since the large volume of the vapor space not directly above the cold cap is dominated by the flow fields of air. Thus, the impact of non-prototypic melter design on fluid mixing is significant in the absence of active air purge, while the impact becomes small or even negligible with active air purge. However, in order to achieve comparable mixing efficiencies, a higher rate of air purge will be required per unit melt surface area for the melter with a higher vapor space-to-melt pool cross-sectional area ratio. But the drawback of increased air purge is significant cooling of the vapor space, which adversely impacts both combustion and glass production rates. Figure 6-13 also shows that cooling of the vapor space by air inleakage is more pronounced at a higher vapor space-to-melt pool cross-sectional area ratio.
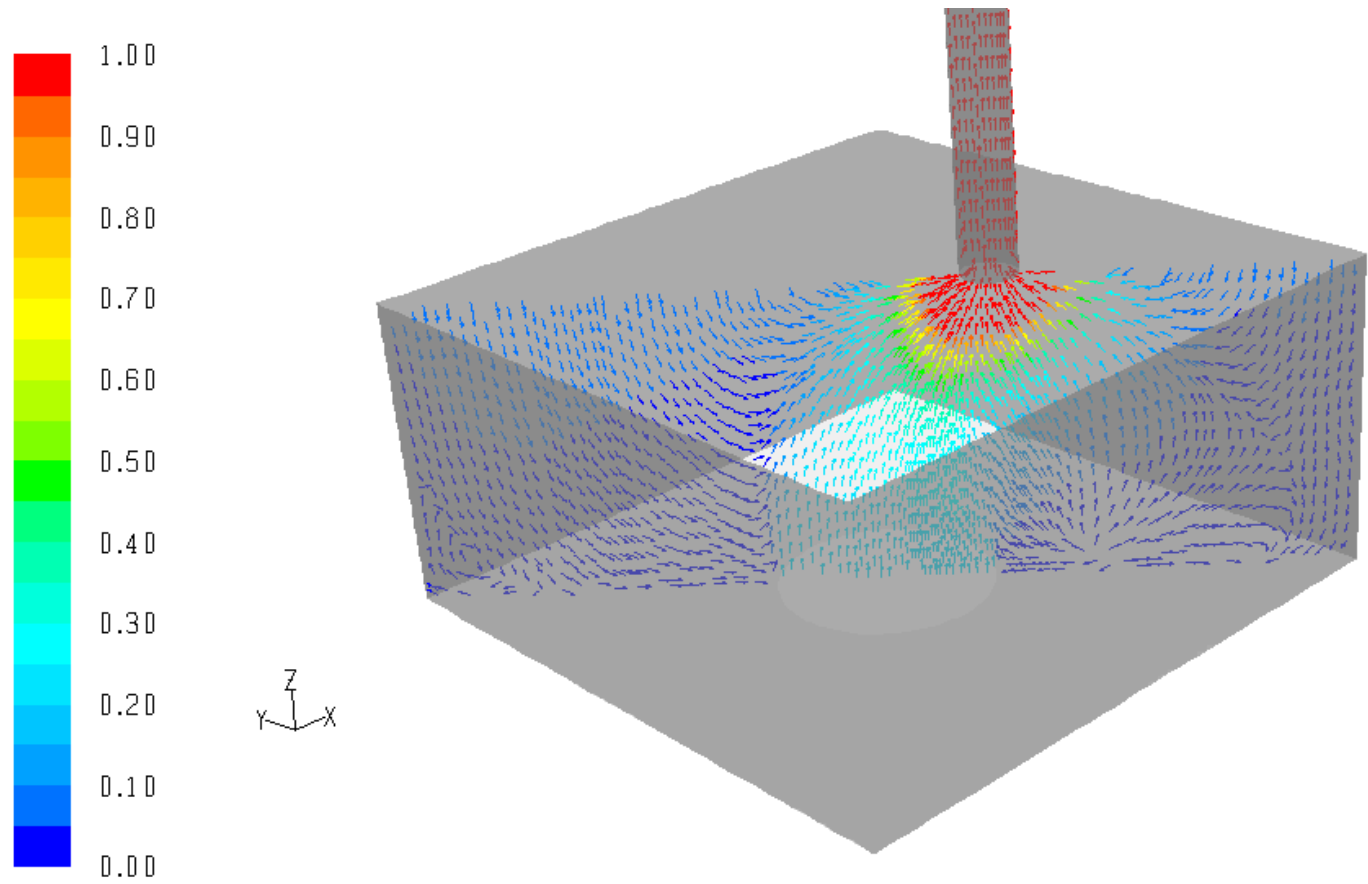

Figure 6-12. Vertical Center-Cut Vector Plot of Gas Velocities in ft/sec (Case: 774-A 20\%). 

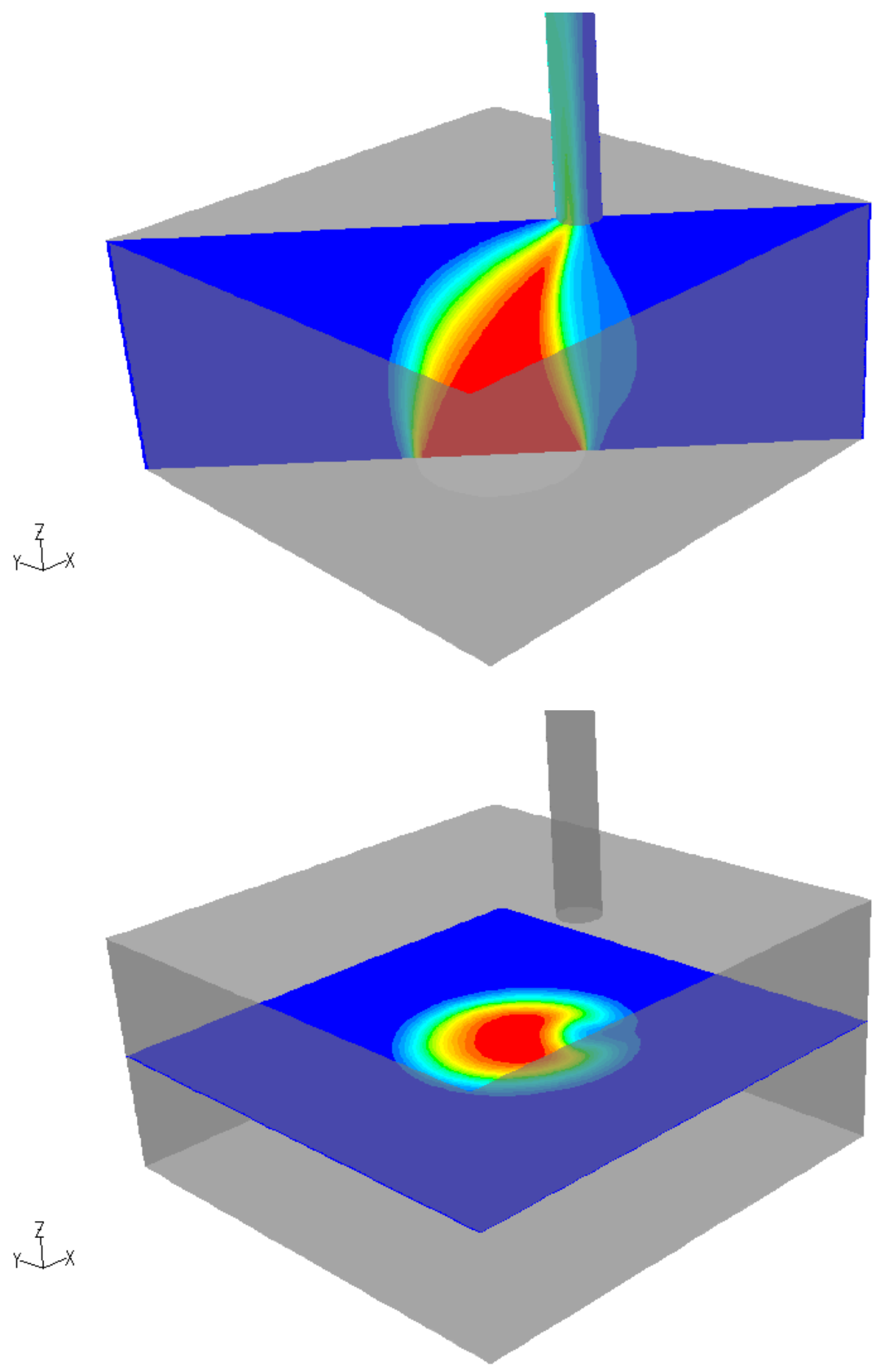

Figure 6-13. Center-Cut Views of Gas Mixing in Mass Fractions (Case: 774-A 20\%). 


\subsection{Conclusions}

The impact of melter internal design on the overall combustion efficiency was investigated by means of a comprehensive review of relevant data in the literature, thermodynamic and kinetic modeling of melter reactions and, finally, CFD modeling of fluid mixing under various design and operating conditions. Based on the results of the data review and modeling, the following conclusions are drawn:

1. Since the DWPF global combustion model implicitly includes in its parameters such transport effects as fluid mixing and heat transfer as well as intrinsic kinetics, it should in principle be only applicable to the prototypic melters that exhibit similar transport effects.

2. When melter configurations were prototypic of the DWPF melter based on similar vapor space-to-melt pool cross-sectional area ratios and, to a lesser extent, similar melt pool aspect ratios, the existing DWPF cold cap and global combustion models successfully predicted measured $\mathrm{H}_{2}$ and $\mathrm{CO}$ data from the prototypic PSCM-23 run. Although the applicability of the DWPF models to the prototypic RSM run data could not be proved as firmly due to the fact that measured $\mathrm{H}_{2}$ and $\mathrm{CO}$ data were near detection limits, the model predictions were still found to be consistent with the data.

3. When melter configurations were non-prototypic of the DWPF melter based on dissimilar vapor space-to-melt pool cross-sectional area ratios and dissimilar melt pool aspect ratios, the existing DWPF cold cap model under predicted measured $\mathrm{H}_{2}$ and $\mathrm{CO}$ data from the non-prototypic DM10-A2 and DM10-SB6 runs. The most likely cause for the under prediction is that gas bypassing in the DM10 cold cap may have been more extensive than in a prototypic melter cold cap. Further analysis of data suggests that gas bypassing may be more design related rather than operational.

4. The existing DWPF cold cap and global combustion models under predicted measured $\mathrm{H}_{2}$ and $\mathrm{CO}$ data from the non-prototypic DM100-A2 run. It is not known which of the two DWPF models is more responsible for the under prediction. If it were the cold cap model, gas bypassing would be the likely cause. If it were the global combustion model, nonrepresentative fluid mixing and heat transfer of the DM100 vapor space would be the likely cause.

5. It is not certain how the melt pool aspect ratio would affect cold cap off-gas bypassing during non-bubbled operation. However, it was reasoned that the vapor space-to-melt pool cross-sectional area ratio may play a role; the higher the cross-sectional area ratio, the more radiant heat the cold cap would receive and subsequent acceleration of the physical and chemical changes that the cold cap residues undergo would likely lead to more process irregularities including bypassing of gases between the cold cap stages. The resulting calcine gases would then be more flammable than would be predicted from the ideally-staged thermodynamic equilibrium construct of the DWPF cold cap model.

6. The results of CFD modeling showed that active air purging greatly improves mixing in the melter vapor space, thus lessening the impact of melter internal design on the overall combustion efficiency. This appears to be the main reason for the successful validation of the DWPF models against the data taken from the SCM-2 and 774-A melter runs despite their non-prototypic vapor space-to-melt pool cross-sectional area ratios. 
7. However, one major drawback of active air purging is that it cools the vapor space and thus adversely affects both combustion and glass production rates. The rate of active air purge (per unit melt surface area) necessary to maintain comparable mixing efficiency increases with increasing vapor space-to-melt pool cross-sectional area ratio, since higher air purge would be required to maintain similar flow fields and mixing profiles in a larger vapor space. This additional air purge necessary to overcome non-prototypic design and subsequent cooling of the vapor space would be difficult to scale up.

8. The results of CFD modeling also showed that in the absence of active air purge, the flow fields and mixing profiles in a prototypic melter vapor space are markedly different from those in a non-prototypic melter. Particularly, the passive cooling of the vapor space is much more pronounced in a non-prototypic melter than in a prototypic melter.

9. Since process chemistry, mixing, and heat transfer in the DWPF melter are represented by a simplified set of models, including the global kinetic model for the vapor space combustion, the further the test configurations deviate from the key design parameters described in this document, the greater the risk that the test results and conclusions will not represent the DWPF. As a result, scale-up of the data taken from a non-prototypic melter will be more challenging and, therefore, more risky than scale-up of the data taken from a prototypic melter. 


\section{References}

1. Wagnon, T. J., "Defense Waste Processing Facility Alternate Reductant Systems Engineering Evaluation," G-AES-S-00003, Rev. 0, Savannah River Remediation, Aiken, SC, August 3, 2011.

2. Choi, A. S., "Melter Off-Gas Flammability Assessment for DWPF Alternate Reductant Flowsheet Options," SRNL-STI-2011-00321, Rev. 0, Savannah River National Laboratory, Aiken, SC, July 2011.

3. Choi, A. S., "Validation of DWPF Melter Off-Gas Combustion Model," WSRC-TR2000-00100, June 23, 2000.

4. Choi, A. S., "Validation of DWPF MOG Dynamics Model - Phase I (U)," WSRC-TR96-0307, January 7, 1997.

5. Choi, A. S., "DWPF Melter Off-Gas Flammability Assessment (Sludge Batch 7b)," X-CLC-S-00164, Rev. 7, Savannah River National Laboratory, Aiken, SC, September 14, 2011.

6. Choi, A. S., "DWPF Melter Off-Gas Flammability Assessment," $\boldsymbol{X}$-CLC-S-00164, Rev. 3, Savannah River National Laboratory, Aiken, SC, August 2010.

7. Choi, A. S., Rabon, G. F., Smith, M. E., Goudelock, S. L., Crow, K. R., Wehner, A. M., and Baron, M. R., "Summary of Campaigns SGM-9 and SGM-10 of the DWPF Scale Glass Melter (U)," DPST-88-626, E. I. du Pont de Nemours \& Co., Aiken, SC, December 15, 1988.

8. Holman, J. P., Heat Transfer, $9^{\text {th }}$ Ed., McGraw-Hill, NY, 2002.

9. Matlack, K. S., Gong, W., and Pegg, I., "Final Report - Compositional Variation Tests on DuraMelter 100 with LAW Sub-Envelope A3 Feed in Support of the LAW Pilot Melter," VSL-01R62N0-1, Rev. 2, Vitreous State University, The Catholic University of America, Washington, DC, January 8, 2002.

10. Wright, G. T., "SCM-2 Off-Gas Film Cooler," DPST-83-613, E. I. du Pont de Nemours \& Co., Aiken, SC, June 22, 1983.

11. Ritter, J. A., Andrews, M. K., Hutson, N. D., Miller, D. H., Smith, M. E., and Zamecnik, J. R., "Integrated DWPF Melter System Campaign Report Coupled Feed Operation (U)," WSRC-TR-90-131, Westinghouse Savannah River Co., Aiken, SC, March 1, 1990.

12. Choi, A. S., "Prediction of Melter Off-Gas Explosiveness," WSRC-TR-90-346, Westinghouse Savannah River Co., Aiken, SC, January 22, 1992.

13. Lambert, D. P., Boley, C. S., and Zamecnik, J. R., "Alternative Tank 51 Sludge-Only Process Development for the Defense Waste Processing Facility (DWPF) (U)," WSRC-RP-97-40 Revision 1, Westinghouse Savannah River Co., Aiken, SC, March 13, 1997. 
14. Choi, A. S., "DWPF Melter Off-Gas Flammability Calculations for Coupled Feed Flowsheet," $\boldsymbol{X}$-CLC-S-00081, Westinghouse Savannah River Co., Aiken, SC, May 27, 1997.

15. Choi, A. S., Unpublished Results of the DWPF Melter Air Inleakage Calculations, Westinghouse Savannah River Co., Aiken, SC, June 7, 2000.

16. Armstrong, K. M., and Klingler, L. M., "Nitrate Waste Processing by Means of the Joule-Heated Glass Furnace," MLM-3304 UC-70, Monsanto Research Corporation, Mound, OH, October 18, 1985.

17. Crow, K. R., and Sabatino, D. M., "SCM-2 Acid Hydrolysis Run - Sampling Results," DPST-84-659, E. I. du Pont de Nemours \& Co., Aiken, SC, July 30, 1984.

18. Crow, K. R., "SCM-2 Off-Gas Results for Sludge-Precipitate Feed," DPST-85-575, E. I. du Pont de Nemours \& Co., Aiken, SC, August 5, 1985.

19. Choi, A. S., and Smith, III, F. G., "RPP-WPT LAW Melter Off-Gas Flammability Assessment," WSRC-TR-2003-00130, Rev. 0, Westinghouse Savannah River Co., Aiken, SC, September 2003.

20. Bone, William, and Gardner, J. B., "Comparative Studies of the Slow Combustion of Methane, Methyl Alcohol, Formaldehyde, and Formic Acid," Proc. Roy. Soc., vol. A, pp297-328 (1936).

21. Saito, K., Shiose, T., Takahashi, O., Hidaka, Y., Aiba, F., and Tabayashi, K.," Unimolecular Decomposition of Formic Acid in the Gas Phases On the Ratio of the Competing Reaction Channels," J. Phys. Chem. A, 109, 5352-5357 (2005).

22. Goles, R. W., and Nakaoka, R. K., "Hanford Waste Vitrification Program Pilot-Scale Ceramic Melter Test 23," PNL-7142, Pacific Northwest Laboratory, Richland, WA, February 1990.

23. Matlack, K. S., Kot, W. K., D’Angelo, N., Pegg, I. L., Diener,* G. A., and Joseph,* I. "Final Report-Melter Testing of Alternate Reductant Flow-Sheets for the Defense Waste Processing Facility," VSL-11R2020-3, Rev. 0, Vitreous State Laboratory, The Catholic University of America, Washington, DC, and EnergySolutions Federal EPC, Inc., ${ }^{*}$ Columbia, MD, April 26, 2011.

24. Goles, R. W., Buchmiller, W. C., Jagoda, L. K., MacIsaac, B. D., and Rassat, S., "Test Summary: WTP Flowsheet Evaluation of Mercury-Containing Hanford Waste Simulant," PNWD-3437, Battelle - Pacific Northwest Division, Richland, WA, April 2004.

25. Matlack, K. S., and Pegg, I. L., "Data Summary Report Plenum Gas Sampling during LAW DM10 and DM1200 Tests in Support of Flammability Models," VSL-03S3850-1, Rev. 0, Vitreous State Laboratory, The Catholic University of America, Washington, DC, January 7, 2003.

26. Matlack, K. S., Kot, W. K., D’Angelo, N., Pegg, I. L., Diener,* G. A., and Joseph,* I. "Final Report-Off-Gas Data from DM10 Melter Testing of Alternate Reductant FlowSheets for the Defense Waste Processing Facility," VSL-11R2020-4, Rev. 0, Vitreous 
State Laboratory, The Catholic University of America, Washington, DC, and EnergySolutions Federal EPC, Inc., * Columbia, MD, April 26, 2011.

27. Choi, A. S., " Melter Off-Gas Flammability Assessment for DWPF Alternate Reductant Flowsheet Options," SRNL-STI-2011-00321, Rev. 0, Savannah River National Laboratory, Aiken, SC, July 2011.

28. Matlack, K. S., Schatz, T. R., and Pegg, I. L., "Data Summary Report Off-Gas Hydrogen Concentrations in Tests on the DuraMelter 100 Melter System Using LAW Sub-Envelope A1 and A2 Simulants," VSL-02S4100-1, Rev. 0, Vitreous State Laboratory, The Catholic University of America, Washington, DC, February 8, 2002.

29. Matlack, K. S., Gong, W. and Pegg, I. L., "Compositional Variation Tests on DuraMelter 100 with LAW Sub-Envelope A2 Feed (LAWA88 Glass) in Support of the LAW Pilot Melter" VSL-02R62N0-3, Rev. 1, Vitreous State Laboratory, The Catholic University of America, Washington, DC, January 31, 2003.

30. FLUENT ${ }^{\circledR}$ 6.3, Fluent, Inc., Lebanon, NH, 2008.

31. Choi, A. S., "DWPF Melter Off-Gas Flammability Assessment (Sludge Batch 6 and 7A)," X-CLC-S-00164, Rev. 5, Savannah River National Laboratory, Aiken, SC April 7, 2011 .

32. Jones, W. P., and Launder, B. E., "The Prediction of Laminarization with a Two Equation Model of Turbulence", Int. J. of Heat Mass Transfer, vol. 15, pp. 301-314, 1972.

33. Lee, S. Y., Dimenna, R. A., Leishear, R. A., and Stefanko, D. B., "Analysis of Turbulent Mixing Jets in a Large Scale Tank", ASME Journal of Fluids Engineering, vol. 130, Number 1, pp. 011104 (2008).

34. Dimenna, R. A., Lee, S. Y., and Tamburello, D. A., "Advanced Mixing Models", SRNL-STI-2011-00026, Savannah River National Laboratory, Aiken, SC, February 2011. 
SRNL-STI-2012-00121

Revision 0

This page left intentionally blank 


\section{Distribution:}
A. P. Fellinger, 773-41A
S. D. Fink, 773-A
K. M. Fox, 999-W
B. J. Giddings, $786-5 \mathrm{~A}$
C. C. Herman, 999-W
C. M. Jantzen, 773-A
D. P. Lambert, 999-W
S. L. Marra, 773-A
D. K. Peeler, 999-W
F. M. Pennebaker, 773-42A
M. E. Stone, 999-W
W. R. Wilmarth, 773-A
J. M. Bricker, 704-27S
T. L. Fellinger, 704-26S
E. W. Holtzscheiter, 704-15S
J. F. Iaukea, 704-30S
M. T. Keefer, 241-156H
J. E. Occhipinti, 704-S
W. O. Pepper, 704-S
J. W. Ray, 704-S
M. A. Rios-Armstrong, 241-156H
A. Samadi-Dezfoul, 704-27S
D. C. Sherburne, 704-S
M. E. Smith, 704-30S
A. V. Staub, 704-27S
J. P. Windham, 704-30S
P. R. Jackson, DOE-SR, 703-46A
K. H. Subramanian, 766-H 